\title{
Economic Consequences of the U.S. Convict Labor System
}

\author{
Michael Poyker*\#
}

Working Paper No. 91

February 2019

\begin{abstract}
Prisoners employed in manufacturing constitute $4.2 \%$ of total U.S. manufacturing employment in 2005; they produce cheap goods, creating labor demand shock. I study the economic externalities of convict labor on local labor markets and firms. Using newly collected panel data on U.S. prisons and convict-labor camps from 1886 to 1940, I calculate each county's exposure to prisons. I exploit quasi-random variation in county's exposure to capacities of pre-convict-labor

\footnotetext{
* Columbia University. Correspondence at: Columbia Business School, Uris Hall, 126; 3022 Broadway; New York, NY; 10027; mp3780@columbia.edu.

\# This paper is based on the first chapter of my Ph.D. dissertation at UCLA. I am grateful to Christian Dippel, Paola Giuliano, Daniel Posner, Peter Rossi, Nico Voigtländer, and Romain Wacziarg for their advice and guidance. I also thank Omer Ali, Maxim Ananyev, Elliott Ash, Sascha Becker, Kirill Borusyak, Gregory Clark, Dora Costa, Sebastián Edwards, Katherine Eriksson, James Fenske, Thomas Ferguson, Stefano Fiorin, Edward Glaeser, Walker Hanlon, Vasily Korovkin, Edward Leamer, Adriana Lleras-Muney, Alexey Makarin, Daniel Nagin, Suresh Naidu, Imil Nurutdinov, Brendan O'Flaherty, Sebastian Ottinger, Bruno Pellegrino, Ricardo Pérez-Truglia, Konstantin Platonov, Stephen Ross, Joseph Stiglitz, Yuan Tian, Daniel Treisman, Till von Wachter, Melanie Wasserman, Meng $\mathrm{Xu}$, conference participants at AEA, ALEA, All-California Labor Economics, All-UC Economic History Group, All-UC Economic History Graduate Student Workshop, APSA, Cliometric Society, EHS, INET YSI, UC Anderson GEM - BPP Haas Workshop, UEA, and seminar participants at CERGE-EI, CMU Heinz College, Columbia University, LSE Economic History, UC Irvine, UCLA, and UNSW for excellent suggestions. I am grateful to Professor Richard Hornbeck, who generously provided historical manufacturing data. I also acknowledge generous nancial support from the Economic History Association and the UCLA Ziman Center for Real Estate.
} 
prisons as an instrument. I find that competition from cheap prison-made goods led to higher unemployment, lower labor-force participation, and reduced wages (particularly for women) in counties that housed competing manufacturing industries. The introduction of convict labor accounts for 0.5 percentage-point slower annual growth in manufacturing wages during 18801900. At the same time, affected industries had to innovate away from the competition and thus had higher patenting rates. I also document that technological changes in affected industries were capital-biased.

JEL Codes: J23, J31, J47, N31, N32, N71, N72, O33, R12

Keywords: Convict Labor, Labor Competition, Patenting, Technology Adoption 
While labor coercion in agricultural and preindustrial economies is well-studied, few papers address the effects of coercive institutions in an industrial setting (Naidu and Yuchtman (2013)). The most common form of labor coercion in modern times is convict labor: it is still widespread, not only in developing countries but also among the world's most developed countries. ${ }^{1}$ This practice is potentially important to the economy because a large share of labor, working at significantly below the minimum wage, could impose externalities on the broader non-coerced segment of the labor market. In 2005, the U.S. convict-labor system employed nearly 1.4 million prisoners, of which 0.6 million worked in manufacturing (constituting $4.2 \%$ of total U.S. manufacturing employment). ${ }^{2}$ Prisoners work for such companies as Wal-Mart, AT\&T, Victoria's Secret, and Whole Foods, and their wages are substantially below the minimum wage, ranging from $\$ 0.20$ to $\$ 5.15$ per hour in state prisons. ${ }^{3}$

This paper provides empirical evidence on how convict labor affects local labor markets. Using a new dataset of U.S. prisons from 1886 to 1940, I calculate each county's exposure to competition with prison-made goods. I find that the 1870-1886 introduction of convict labor accounts for a 0.5 percentage-point slower annual growth rate in manufacturing wages from 1880 to 1900. At the same time, affected industries had to innovate away from the competition and thus had higher patenting rates and adopted new labor-saving technologies.

The economics of convict labor are straightforward. Prisoners employed in manufacturing production cannot be employed by any firm on the competitive market. Prison-made goods are relatively cheap because the cost of convict labor is lower than the reservation/minimum wages of free laborers. Thus convict labor decreases labor demand in a similar way to import competition shocks. While an active literature in economics has investigated local demand shocks due to import competition (among others Autor, Dorn and Hanson (2016)), no economics paper has yet addressed such shocks due to convict labor.

Previous work has not been able to study this issue due to lack of data and due to a lack of exogenous variation in convict labor. U.S. prisons tend to be built in economically depressed counties under the assumption that they will provide jobs (e.g., guards and nurses) in the local labor market (Chirakijja (2018)), so cross-sectional estimates comparing prison towns to others would have selection bias. Similarly, trends in recent convict-labor legislation may be correlated with trends in states' budgetary health, which is directly related to local labor market

\footnotetext{
${ }^{1}$ In addition to convict labor, other types of coerced labor such as military labor, peonage, indentured labor, debt bondage, and sharecropping still exist (van der Linden and García (2016)). For example, in Egypt, the army employs conscripted soldiers in factories to produce an array of products, from televisions and pasta to refrigerators and cars (Al Jazeera, (2012)). China and Russia employ up to 2 million and 0.5 million convicts, respectively (see Forbes (2013) and Research Foundation, Laogai (2006)).

${ }^{2}$ Sources: Census of State and Federal Adult Correctional Facilities, 2005, and FRED. Assuming the share of employed prisoners to be on the 2005 level, they constituted $10 \%$ of total U.S. manufacturing employment in 2017.

${ }^{3}$ For more information on wages and companies working with prisons, see Prisonpolicy.org and Daily Kos (2010). The situation is not unique to the United States. For example, U.K. prisons "lease out" inmates to local firms, allowing them to pay $6 \%$ of the minimum wage (The Guardian (2012)).
} 
conditions.

This paper addresses both the lack of data and lack of exogenous variation. The empirical context is U.S. counties for the years 1886 through 1940. These data come from a newly digitized archive of the Bureau of Labor's reports on convict labor used in all U.S. prisons and labor camps. Adapting an approach from recent works on import competition (Autor, Dorn and Hanson (2013) and Kovak (2013)), I construct county-level exposure to convict labor as the weighted average of industry-specific values of convict-made goods in all U.S. prisons, where the weights include the county's industry-labor share and the costs of trade between those prisons and the county. In the baseline analysis, I estimate the effect of convict-labor exposure on manufacturing wages and employment using firstdifference ordinary-least-squares (OLS) regressions. To address the concern that the location of prisons and the choice of industries by prisons might be endogenous, I employ an instrumental-variable (IV) estimation. Exogenous variation in the use of convict labor comes from the fact that prisons built before the 1870s (when state laws introduced convict labor) did not have the facilities and infrastructure for factory production. The introduction of convict labor was unanticipated, both by firms and by prison wardens, who were suddenly in charge of employing prisoners within their institutions. Pre-existing prison capacities are correlated with the value of goods produced in prisons after convict-labor laws were enacted. Therefore, my instrument for exposure to convict labor is the exposure to pre-existing prison capacities; i.e., I compare counties that were located closer to prisons built before convict-labor legislation to the ones located farther away from the pre-convict-labor-era prisons (hereafter, old prisons).

The validity of the instrument relies on the assumption that conditional on factors important to the location of the old prisons, it is uncorrelated with wardens' choices of industrial composition of convict labor, and possible strategic location of prisons constructed after convict-labor laws were enacted. ${ }^{4}$ To check exogeneity, I show that the exposure to old prison capacities is uncorrelated to pre-convict-labor changes in wage growth at the county and industry levels. The first-differences specification allows me to account for time- and county-invariant unobserved heterogeneity, and the pretreatment level and trends in dependent variables account for possible mean-reversal and trend-breaks.

I find that the 1870-1886 introduction of convict labor decreases manufacturing wages and employment. Comparing two counties, one at the 25th percentile and the other at the 75 th percentile of exposure to convict labor, the more exposed county would on average experience a 0.4 -percentage-point slower growth rate in manufacturing wages, a 0.3 -percentage-point slower growth rate in manufacturing employment share, and a 0.12-percentage-point slower growth rate in labor-force participation annually. ${ }^{5}$ I find no effect on manufacturing outcomes when using

\footnotetext{
${ }^{4}$ Old prison locations were determined primarily by population size and urban share of population.

${ }^{5}$ The size of the effects of the convict-labor shock is comparable to the size of the effects of the "China shock" (Autor, Dorn and Hanson (2013)): it is $63 \%$ in terms of manufacturing employment, $143 \%$ in
} 
placebo exposure to convict-labor output in farming. My results are robust to (1) changing the exposure to convict labor by using only trade costs (i.e., disregarding industry shares) or only industry weights (i.e., disregarding trade costs); (2) changing the measure of exposure to convict labor to be as in Autor, Dorn and Hanson (2013); (3) using alternative ways of constructing the baseline measure of convict-labor exposure (by weighting distance-to-prison instead of trade costs, by using alternative decay of iceberg costs, by using alternative industry weights, and by using the number of employed convicts instead of the value of prison-made goods); (4) using only counties that employed convict labor as "treated." 6

While prison labor was used in many industries, most prisons produced clothes and shoes. The apparel and shoemaking industries employed mostly women, who were more affected than men by coerced labor. I find that women's wages decreased 3.8 times more than those of men.

I find that convict-labor shocks facilitated technology adoption. Comparing two counties, one at the 25 th percentile and the other at the 75 th percentile of exposure to convict labor, the more exposed county would be expected to experience double the mean annual number of registered patents (8.4) in industries where prisoners were employed (with no effect on patents in industries where prisoners were not employed), and a 0.18-standard-deviation increase in the capital-labor ratio.

The latter result is partially driven by adoption of new technologies (decreasing the costs, increasing the quality of goods, or substituting labor with capital) and these technological changes were capital-biased. I provide three pieces of evidence on potential mechanisms. First, using firm-level survey data from the Weeks Report (Meyer (2004)), I show that firms in affected industries and localities were more likely to adopt improved labor-saving machinery, as competition in (low-skilled) labor became futile. Second, using county-industry-level data from Hornbeck and Rotemberg (2018), I show that firms in affected industries and locations invested in technologies associated with increased productivity of capital relative to technologies related to the productivity of labor. Moreover, the set of available technologies - in the words of Caselli and Coleman (2006), the "technological frontier" - of affected firms improved. Third, I demonstrate that the returns-to-capital relative to returns-to-labor ratio increased by 0.5 percentage points annually in affected counties (interquartile range). However, the increase in the capital-labor ratio is also driven by changes in industrial composition. Using firm-level data from Atack and Bateman (1999), I show that it is also partially explained by the exit of labor-intensive firms in the affected industries.

Finally, I employ a generalized difference-in-differences panel specification in levels with county and decade fixed effects, using IV for identification. The panel

terms of labor-force participation, and $52 \%$ in terms of manufacturing wages.

${ }^{6}$ By comparing counties with prisons to counties adjacent to them and to second-order adjacent counties, I find that the effects of convict labor are stronger in counties with prisons and that the effects decay with distance. My results are not driven entirely by the extensive margin: I find that the results hold within the sample of counties with prisons. 
spans from 1850 to 1950, allowing me to directly control for county-specific trends, and to use all available variation in convict-labor output, opening and closure of prisons, and changes in convict-labor legislation. However, this specification is subject to the same endogeneity concerns. To construct a cross-sectional and time-varying instrument, I use the fact that timing of convict-labor laws varied from state to state. As all convict-labor decisions were determined at the prison level, subsequent changes in convict-labor laws were exogenous to the choices of individual prison wardens. Assuming that wardens had no effect on the timing of convict-labor-related laws or the partisan composition of state legislatures, I use the interaction of convict-labor legislation and the capacities of old prisons as an instrument for a county's exposure to convict labor. The panel specification yields similar estimates.

This paper is the first in the literature to estimate the economic effects of convict labor. My results relate to three broad strands of the economic literature. First, the literature on coercive institutions, summarized by (among others) Acemoğlu and Wolitzky (2011), typically focuses on agricultural outcomes (e.g., Naidu (2010)) or on long-run effects. ${ }^{7}$ I contribute to the literature by estimating short-run effects of convict labor. ${ }^{8}$ This paper also speaks to the large literature related to U.S. labor markets (Fishback (1998), Goldin (2000), and Naidu and Yuchtman (2016)) — the historical setting allows me to document the effects of convict labor in a developed country during a period lasting almost 80 years.

Second, the effects of convict labor are similar to the impact of trade-induced low-skilled labor competition (Topalova (2010), Kovak (2013), and Autor, Dorn and Hanson (2013)). ${ }^{9}$ I find that local labor-market shocks can come from convict labor, and these shocks are economically significant: the literature and policymakers may not have appreciated this as a major source of labor-market shock. I find a significant effect of convict labor on both the county-industry level and the state-industry level. I emphasize that in the historical setting, because of high transportation costs, the identification comes not only from timing and industrialcomposition variation but also from the spatial variation in prison locations.

Third, my findings relate penitentiary policies to patterns of directed technological progress (Acemoğlu (2007), Acemoğlu and Finkelstein (2008), Lewis (2011), and Hanlon (2015)). In other setups of negative demand shocks, e.g., the China shock (Bloom, Draca and Van Reenen (2016) and Zhang (2018)), firms may try

\footnotetext{
${ }^{7}$ Dell (2010), Nunn and Wantchekon (2011), and Lowes and Montero (2017) examined long-run adverse impacts of forced labor on contemporary health and social capital. Others (Nunn (2008), Acemoğlu, García-Jimeno and Robinson (2012), and Buggle and Nafziger (2018)) have studied the economic consequences of coercive institutions on later institutional development.

${ }^{8}$ For example, Naidu and Yuchtman (2013) found that the repeal of Master and Servant Law in Great Britain in 1875 was followed by faster wage growth in counties with high levels of prosecutions per capita, and Nilsson (1994) and Markevich and Zhuravskaya (2018) looked at the immediate effects of abolishing slavery/serfdom on contemporaneous agricultural and industrial outcomes, and on nutrition.

${ }^{9} \mathrm{My}$ findings also relate to the literature on the effects of in/out migration on local labor-market outcomes (Card (1990, 2001), Borjas (2003, 2017), Ottaviano and Peri (2012), Hornbeck and Naidu (2014), and Clemens, Lewis and Postel (2018)), and the effects of technology shocks (Goldin and Katz (1998), Katz and Margo (2014), and Acemoğlu and Restrepo (2017)) on local labor-market competition.
} 
to find their way out through changes in technology. Here I show how competition with prison labor led to adoption of both new and existing technologies. I also show that direct technology change can happen not only due to changes in input-factor demand (Acemoğlu (2002)) but also due to local labor-market shocks.

The rest of this paper is organized as follows. Section I introduces the history of U.S. convict labor and describes the novel data. Section II provides records of convict labor's competition with free labor and shows motivating facts. Section III presents my identification strategy and estimation results. Section IV assesses the possible impact of the contemporary U.S. convict-labor system and concludes.

\section{Historical Background and Novel Data on U.S. Convict Labor}

\section{A. Emergence of the Convict-Labor System}

The American penitentiary system appeared in the late 18th century. The system promoted rehabilitation through education and manual labor. In addition prison labor was seen as a source of income to offset states' expenditures for corrections. Prisoners worked in quarries near prisons or crafted goods in solitary cells for sale (Lewis (1922), pp. 68-70). Nevertheless, prisons routinely hemorrhaged cash. ${ }^{10}$ Penitentiary historians are unanimous about the reasons behind this financial failure (e.g., McKelvey (1936)). First and foremost was the prisoners' lack of skill. Most were uneducated and lacked experience in manufacturing jobs. It took years to teach them a skill, and often by the time they learned it, they were already subject to release (Gildemeister (1978), p. 29). Thus, quarrying or masonry were the most popular occupations for convicts before the Civil War. The second reason was the small number of prisoners: prison maintenance costs were low, and states did not have strong incentives to employ prisoners.

However, prison populations soared after the Civil War. In Ohio, New Jersey, and Pennsylvania, they tripled from 1856 to 1886, virtually twice the rate of population growth in those states. ${ }^{11}$ More prisons were needed. ${ }^{12}$ In the wake of the Civil War, states had other budgetary problems, which made them more eager to find ways for their penitentiaries to fund themselves (Wilson (1933)).

The problem with prisoners' skills was solved when factory systems and mechanization were introduced. New types of industrialized machinery replaced many of the manual skills needed to produce particular goods, making low-skilled labor more employable in some industries. And while unionization could protect

\footnotetext{
${ }^{10}$ In 1818, in Auburn, New York, a new type of penitentiary appeared in which prisoners were gathered during the day in a workshop, where they worked together (Gildemeister (1978), p. 16). By 1870, only eight U.S. prisons (all in New York) operated with a modest net profit (Department of Labor (1900)).

${ }^{11}$ Prison data are from the prisons' annual reports; population growth is based on changes from 1860 to 1890 in the decennial population census.

${ }^{12}$ Due to slavery and specific cultural "honor" norms (Grosjean (2014)), by the end of the Civil War ex-Confederate states had only three prisons throughout their territory. One, in Atlanta, was destroyed during the city siege.
} 
such industries as coopers, hatters, molders, and shoemakers in the beginning, it couldn't stave off prison labor. Mechanization enabled prisons to teach convicts one particular task instead of the whole set of skills needed to manufacture certain goods. ${ }^{13}$

The decrease in skill requirements for prison labor and the increase in the number of potential convict laborers pushed states to enact convict-labor legislation. Convict labor actively spread after the creation of the National Prison Association in 1870 and had been introduced in almost all states by the end of the 1877-1881 presidential term of Rutherford B. Hayes, who was a big advocate for the convict-labor system (Wines (1871)). In 1870, about 3,500 of the nation's $32,901(10.6 \%)$ prisoners were working as convict-laborers (all in New York). By 1886, the number had risen exponentially: 45,277 of the nation's $64,349(70.4 \%)$ prisoners were now toiling under the convict-labor system (the blue and red lines in Figure 1). 15,100 (23.5\%) were engaged in prison duties, and 3,972 were sick or idle. For detailed information about the evolution of convict-labor legislation, see Appendix E.

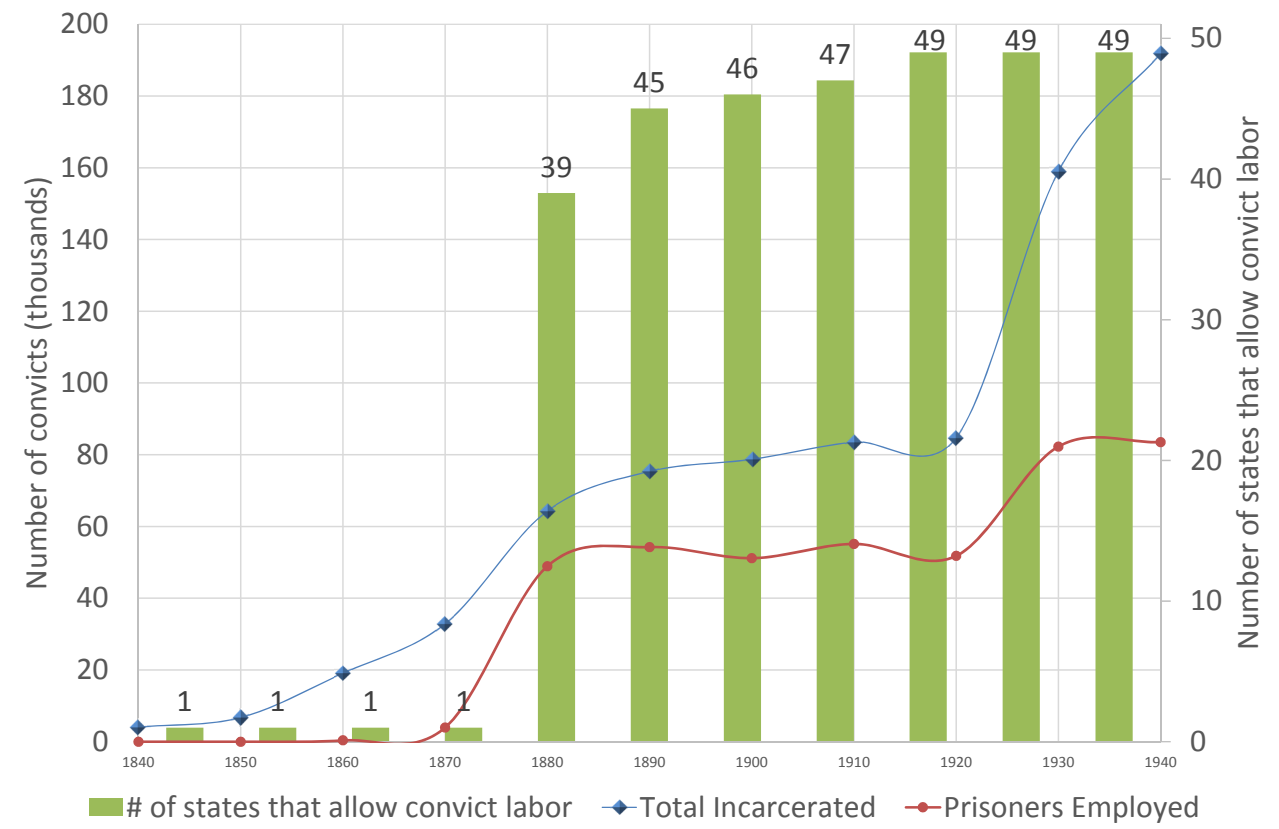

Figure 1. INCARCERATION AND USAGE OF PRISON LABOR, 1840-1940

Note: Prisoners employed in prison duties are not counted as engaged in productive labor. The numbers of employed prisoners for 1860 and 1870 are the upper bounds, as there are no data on how many inmates actually worked, only on the total prison population of the prisons that employed prisoners. Washington, D.C. is included.

${ }^{13}$ For case studies, see Weiss and Weiss (1961) pp. 9, 28, 56, and Gildemeister (1978), pp. 175-180. 


\section{B. Novel Data on U.S. Convict Labor}

The primary source of the data for this paper is a set of U.S. Department of Labor reports devoted to convict labor. As competition between convict labor and free labor was a widely discussed topic at the time, the Bureau of Labor decided to inspect all penitentiary facilities to determine the level of competition between goods produced under different convict-labor systems and goods produced by free laborers. Approximately every ten years, the Department of Labor issued special reports devoted to convict labor, containing meticulously collected information about employed prisoners and the output of U.S. correctional facilities.

I collected and digitized seven reports for the following years: 1886, 1895, 1905, $1914,1923,1932$, and $1940 .{ }^{14}$ Then, I matched all prisons and convict-labor camps across years by name and location. Overall, the dataset contains 464 different locations with correctional facilities or convict-labor camps.

The data were collected by Bureau of Labor employees who traveled directly to prisons and filled out the surveys according to the accounting books provided by prisons. ${ }^{15}$ The data include all prisons, houses of correction, and convict-labor camps, as well as juvenile reformatories and industrial schools. Local county jails are included only if they employed prisoners.

I assign two-digit SIC codes according to the 1987 SIC manual to every item produced in prison: the data do not contain industry codes, but they do include specific articles of produced goods (e.g., "cane-seating chairs" and "clothing, men and boys"). Then, I sum up the item values to generate industry-level output values. All dollar values throughout the paper are normalized to 1880 dollars.

All my outcomes are for the manufacturing sector, so in this paper I use only convict labor in manufacturing (SIC codes 20-39). In addition, road construction and other infrastructure projects may have had a positive effect on economic outcomes. This issue goes beyond the scope of this paper, but it merits future research.

Convict labor was widespread across the United States, and most prisoners were employed in the North. Figure 2 illustrates the distribution of U.S. prisons in 1923. The red dots represent the total value of goods produced in those prisons: the most productive prisons were concentrated in the Northeast and the Midwest. For completeness, Figure A1 shows locations of all prisons and labor camps in my dataset.

In addition to its geographic diversity, convict labor was also employed across almost all industries. However, it was used predominantly in manufacturing, primarily in the production of shoes and clothes. For example, Figure 3 shows the distribution of convict labor by industry in 1923. Almost 30\% of the total value of prison-made goods was produced in the apparel industry, and $15 \%$ was

\footnotetext{
${ }^{14}$ The Department of Labor stopped collecting the data after convict labor was abolished in 1941; it did not resume data collection after convict labor was reestablished, in 1979.

${ }^{15}$ All the data were collected in person except for the 1895 report, which was obtained through the mail: prison wardens filled out the surveys themselves and sent them to the Bureau of Labor.
} 


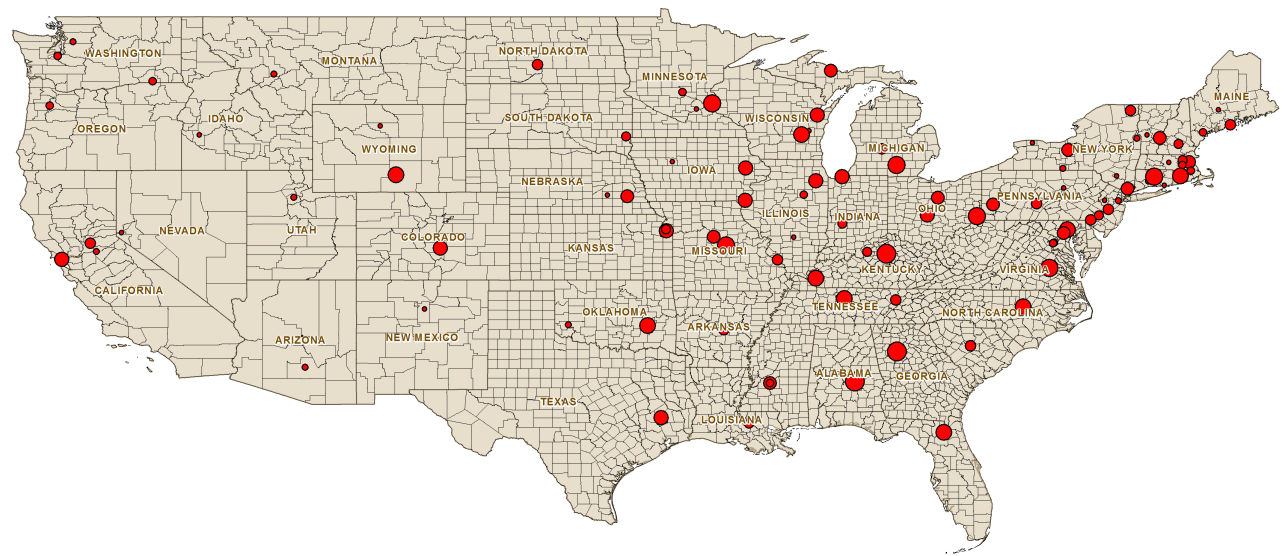

Figure 2. PRisons AND LABOR CAMPS IN 1923

Note: Computed using data from the Department of Labor (1925). Each dot is a prison in 1923. The red dots represent the total value of goods produced in prisons. Convicts employed in road construction ("chain gangs") are excluded.

produced in the textile mill industry.

For the identification purposes that I describe in Section III, I construct a dataset of prison capacities (i.e., beds) existing before convict labor was imposed (in 1870). The 1870 census contains the complete directory of prisons. Most of the prison-capacity data come from the North American Review (1866) and Wines (1871). For the rest of the prisons, the information is from official statelevel reports related to correctional facilities. I use the actual number of inmates to measure prison capacities if that number exceeds the number of beds. ${ }^{16}$

The rest of the data that appear in this paper were used previously by other researchers; I describe these data in great detail in Appendix B.

\section{Convict Labor in the United States: Motivating Facts}

\section{A. Factual Records on Competition Between Convict Labor and Free Labor}

One may think of convict labor as a labor-supply shock. However, this would be only partially true. Only convict leasing allowed firms to freely employ prisoners; the predominantly Southern convict-leasing system employed only $20 \%$ of prisoners at its prime, in 1886 (9,104 inmates), and a scant 3\% in 1914 (1,431 inmates), mostly in mining and quarrying.

\footnotetext{
${ }^{16}$ Data for the actual number of prisoners come from Table XIX of Volume I of the 1870 U.S. population census.
} 


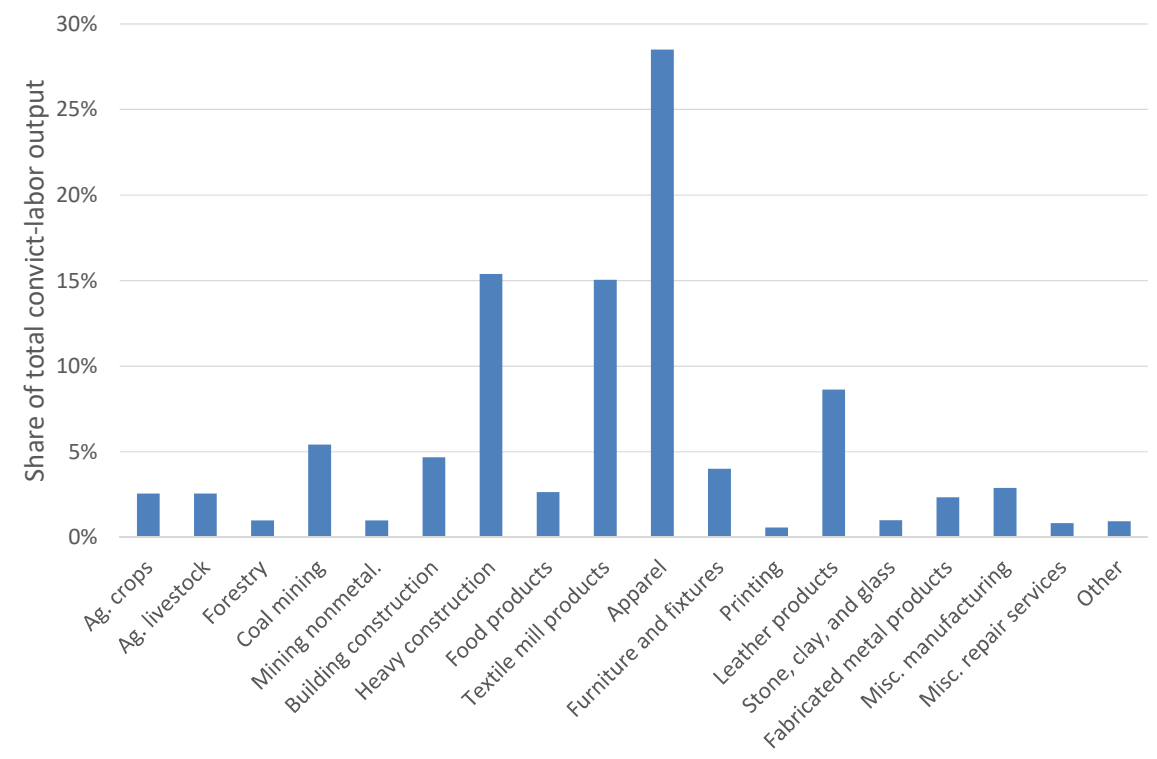

Figure 3. Convict labor by two-digit SIC code (1923)

Note: Data from the Department of Labor (1925).

Most prisoners were employed within the walls of their prisons, and regular firms could not hire convicts directly. ${ }^{17}$ Prisons started to employ prisoners in low-skill-intensive industries and sell final (mostly low-quality) goods on the open market. Prices of prison-made goods were very low: "Our minimum price of bungalow aprons is about one-third higher than the prison-made goods. We can compete with them only because they do not produce enough to supply the market and then only by selling as close as possible to their price on a small margin of profit." 18 In most cases, such unfair competition meant that firms using free labor had to "let them sell their products before we can begin [to sell the same product ourselves]," a twine manufacturer from Minnesota noted. ${ }^{19}$ Thus, a prison can be described as a "firm" producing goods on the open market with access to (limited by prison capacity) labor with a cost lower than cost of free labor and acting like competitive fringe.

Lower prices were possible mainly because prison labor was cheaper than free labor. Prisons either paid too little or nothing at all to the inmates. ${ }^{20}$ In Figure

\footnotetext{
${ }^{17}$ The exception, to some extent, was the contract system, which allowed one firm (or in rare cases a few firms) to employ prisoners within prison premises. However, those firms were often connected to the prison warden, either through collusion or because they were affiliated with his relatives, creating a barrier to entry for anyone but a few to hire cheap prison labor (McKelvey (1934); Gildemeister (1978)).

${ }^{18}$ Department of Labor (1925)), pp. 111-112.

${ }^{19}$ Ibid.

${ }^{20}$ In some states, prisoners were eligible for earlier release as a result of working records. In other states, prisons were obliged to pay lump-sum payments equal to the accumulated wages of the inmates.
} 
4, using data both on the costs of convict labor in state $s$ operating in industry $i$ and on the wages of free workers in those industries and states, I estimate the ratio of the unit-labor costs of convict labor to the wages of free laborers for all two-digit SIC codes where prisoners were employed. Among manufacturing industries, unit-labor costs varied from $8.5 \%$ in stone, clay, and glass to $41 \%$ in primary metal. On average, the cost of prison labor was $19 \%$ of the cost of free labor (black horizontal line).

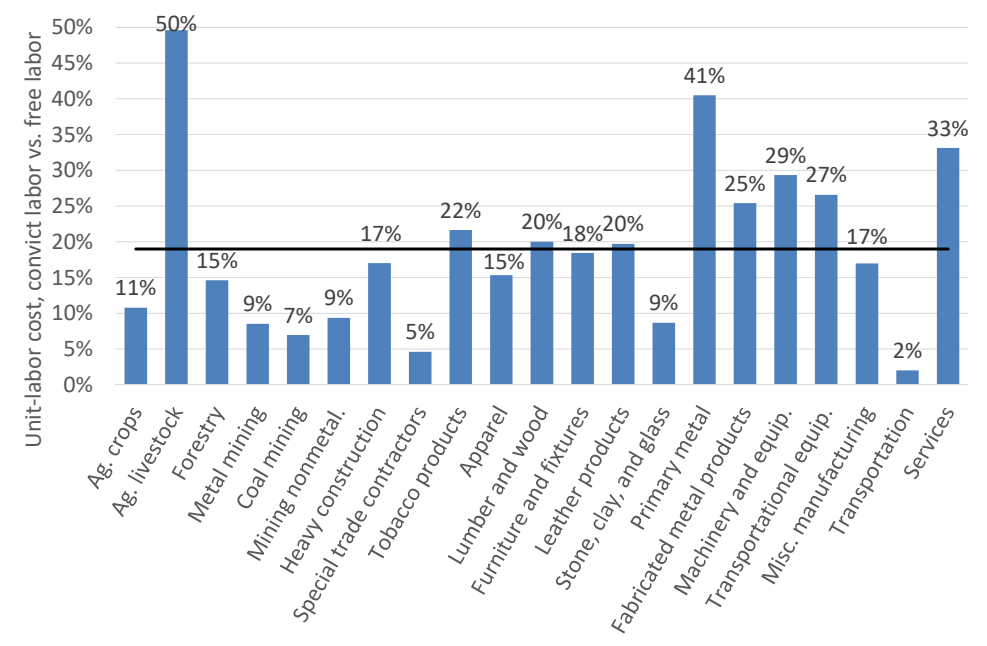

Figure 4. Ratio of cost of Convicts to Cost of Free laborers, 1886

Note: Computed by dividing weekly incarceration expenses per prisoner employed in industry $i$ in state $s$ by a weekly salary of a free worker in industry $i$ in state $s$.

Firms lost money and had to try to decrease their wages. Competition in final-goods markets for certain industries increased and adversely affected labor demand in those industries. Displaced free laborers went to work in other industries, pushing down the average wage in the local labor market. Thus the introduction of convict labor was an adverse labor-demand shock to local free workers. ${ }^{21}$

In 1886, employed prisoners constituted up to $2 \%$ of total U.S. manufacturing employment and produced $4.2 \%$ of total U.S. manufacturing output. While convict labor was used in almost all industries (for example, see Figure A2 for

However, in practice, prisoners were underpaid or received nothing at all (Department of Labor (1887, $1906,1925))$.

${ }^{21}$ I assume that incarceration rates had no effect on local labor supply. As convicts left their county of residence and were sent to one of the prisons in their states, they could decrease labor supply in counties without prisons relative to counties with a prison, and thus make me overestimate the effect of convict labor. However, the average number of people taken from the labor force was small. The earliest available data are from the 1920 census: on average, 62 people were incarcerated in each U.S. county ( $0.18 \%$ of the average county population). 
shares of convict-labor employment by industry in 1886), Panel A of Figure 5 shows that it was concentrated in several industries: it constituted $8.3 \%$ of total employment in leather products, $8.9 \%$ in fabricated metal products, and peaked at $22 \%$ in furniture. But even if it had a relatively small share in some industries (e.g., $4.8 \%$ in apparel), it could constitute a significant share of a state's industry. Panel B of Figure 5 shows the share of employed convicts in the corresponding state's prisons in the total number of employed workers in that state's apparel industry. In South Carolina, for example, there were more prisoners employed than free laborers ( $54.2 \%$ of total employment).
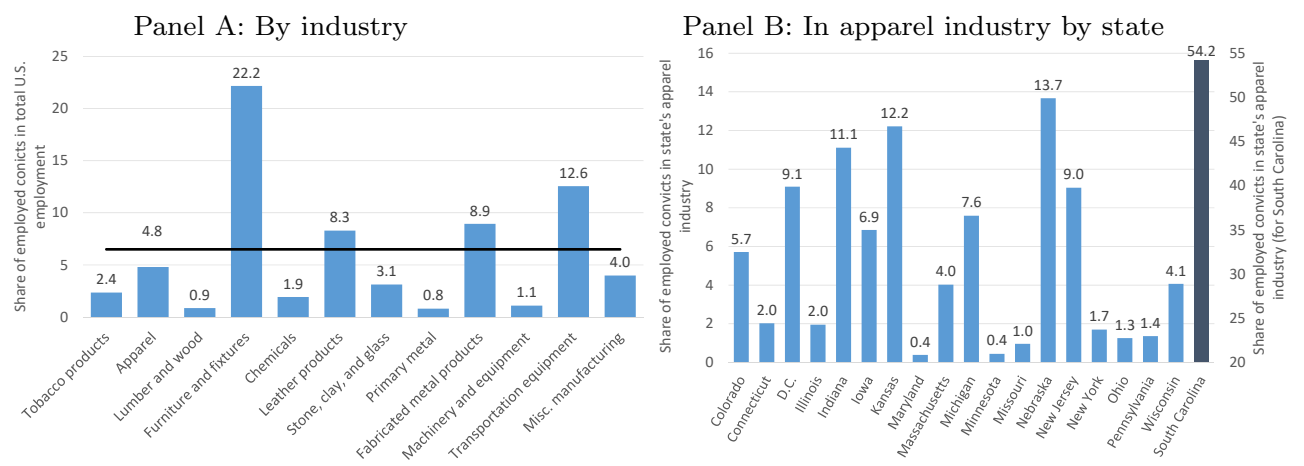

Figure 5. Shares of Employed CONVicts to total LABOR By SELECTED INDUSTRIES IN 1886

Note: The black horizontal line in Panel A represents the share of the total number of employed convicts in the total number of U.S. manufacturing workers (convicts and free) in selected industries (6.5\%). In Panel B, the bar for South Carolina is on the auxiliary Y-axis and is darker for the sake of readability.

\section{B. Preliminary Evidence of the Effects of Convict Labor on Free Labor}

\section{The Industry Matters}

Competition with prison-made goods was a big deal at that time, and the Bureau of Labor frequently investigated complaints about such malevolent competition. $^{22}$ I use one such case investigated by the Industrial Commission on Prison Labor (Department of Labor (1900)) to show that the convict-labor shock was industry-specific and deteriorated with distance.

Coopers in Chicago were producing two types of barrels, "slack" and "tight." Tight barrels required the highest mastery of the craft. It was not until the 1870s that technology and steam-powered machinery revolutionized the craft in response to major new demands in meat-packing, oil, and beer. Meat-packing demands shifted toward lower quality and higher quantity, with new processes

\footnotetext{
${ }^{22}$ In addition to low labor costs, convict labor was criticized for its overlong work hours, physical punishment of prisoners, and unfair tax exemptions for prisons.
} 
and rapid market expansion. In 1882, Joliet State Prison started to produce low-skill-intensive slack meat barrels (IL BLS (1886)). Since prisoners could be contracted at less than one-third the price of Chicago coopers, the operation (even conditional on lower productivity) became profitable. From 1885 to 1895, average annual wages for coopers dropped by $30 \%$, from $\$ 613$ to $\$ 432 .{ }^{23}$ At the same time, the salaries of coopers employed in the production of tight (beer) barrels (which didn't compete with prison labor) decreased by only $8.6 \%$ (Panel A of Figure 6).
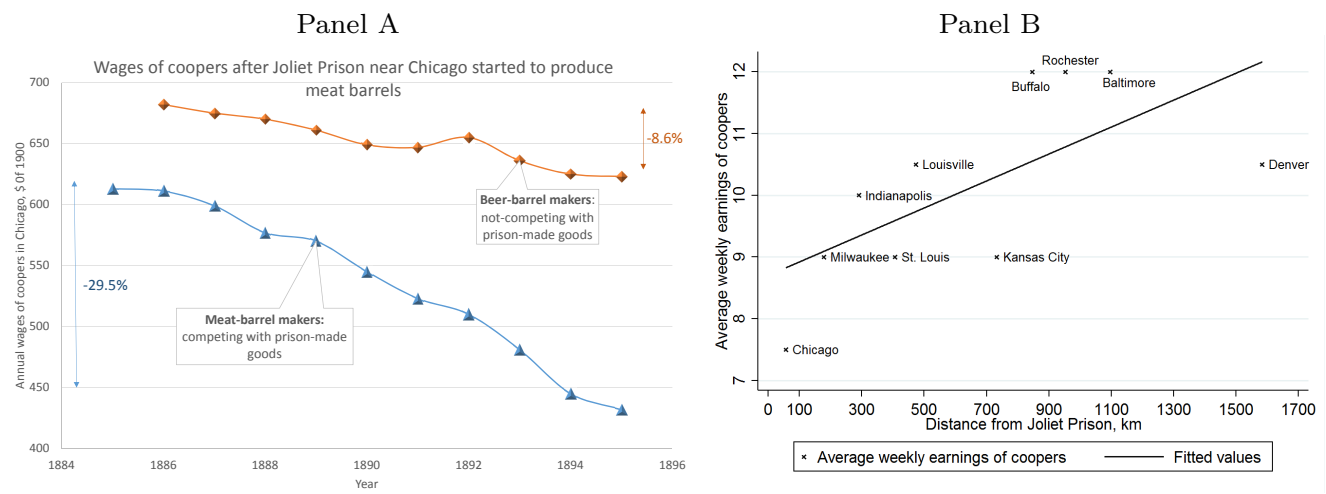

Figure 6. The case of Chicago's Coopers: Wages of Coopers Producing meat and Beer barrels

Note: Annual wages in 1895 dollars. Source: Department of Labor (1900), pp. 38-39.

To demonstrate that the effect of convict labor on wages was industry-specific, in Panels A and B of Figure 7 I plot the exposure of each county to convictmade goods in fabricated metal products and lumber and wood products and changes in log wages in corresponding industries. We can see significant negative correlation: counties more affected by convict-made goods in their industries experienced slower wage growth (faster wage decline). ${ }^{24}$

\section{The Distance from a Prison Matters}

Due to transportation costs, the adverse effect of convict labor on wages of coopers was smaller the farther they toiled from the prison that produced those competing barrels. The Illinois prison depressed wages as far as Milwaukee to the north and Kansas City to the west. In Panel B of Figure 6, I plot the wages of coopers in cities where prison-produced barrels were found by the investigators of the Industrial Commission on Prison Labor against the distance from those

\footnotetext{
${ }^{23}$ Of the 65 Chicago shops employing 686 coopers operating in 1880, 16 shops (235 coopers) had closed by 1885 , and prices for various types of meat packages fell $20 \%$ to $50 \%$.

${ }^{24}$ Figure A3, plots placebo exposure to prison-made goods in the metal (wood products) industry and changes in wages in the wood products (metal) industry, and finds no significant correlation. For completeness, I present a similar example, with two other industries that were exposed to convict labor (leather goods and primary metals), in Figure A4.
} 

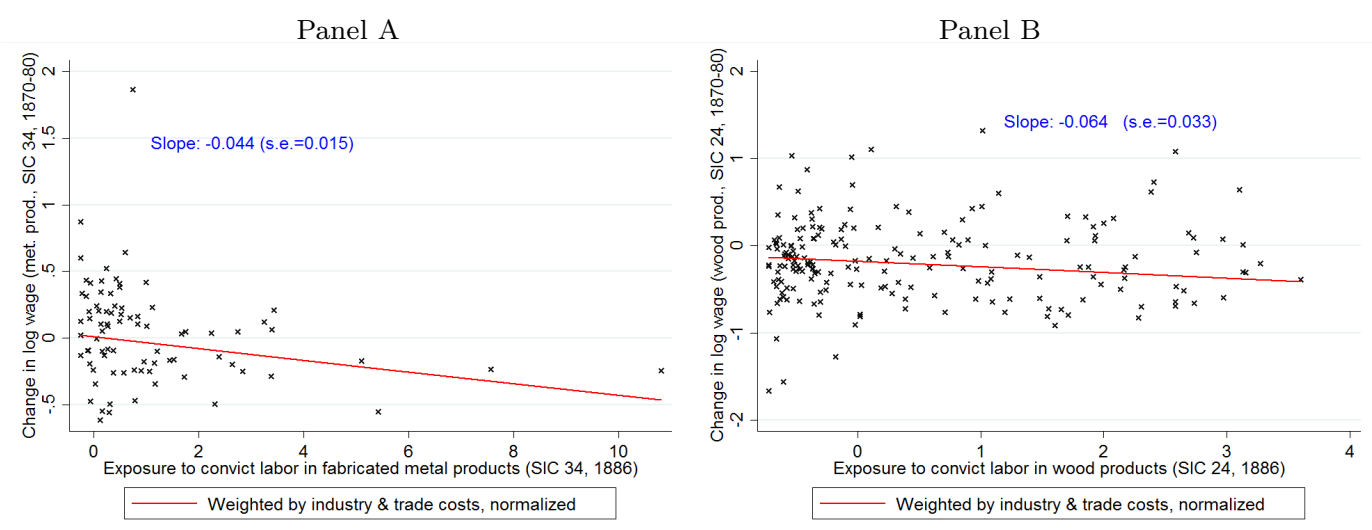

Figure 7. Convict LABor and Changes in MANUfaCturing WAGES IN SELECTED INDUSTRIES

Note: In Panel A (B), each cross is a county that had firms in the fabricated metal products (lumber and wood products (except furniture)) industry. In Panel A (B), exposure to convict labor uses only value of goods produced in the fabricated metal products (lumber and wood products) industry.

cities to the Joliet State Prison. This is consistent with Fogel (1964), Rhode and Strumpf (2003), and Donaldson and Hornbeck (2016), who argue that transportation costs were high at that time.

\section{Defining Convict-Labor Shock}

Convict-labor shock was not an industry-level shock that affected an industry in all regions uniformly, and it was not entirely local. In Figure 8, I plot changes in $\log$ manufacturing wages between 1870 and 1900 on the vertical axis, and the measure of exposure to convict labor on the horizontal axis.

The solid red line represents the measure of the convict-labor shock as the total value of prison-made goods in each industry weighted by the county's industry composition (pure Bartik measure). The slope is negative; however, as the previous figure illustrates, both distance and industry matter. Thus I measure the exposure of each county to prison-made goods by weighting the value of goods produced in each U.S. prison by the cost of trade with counties where those prisons are located. The dashed red line shows the slope for the measure where I weighted by costs-of-trade instead of by industry compositions. The slope of the line is steeper than for the measure with industry weights. Thus, the convict-labor shock was local, and counties located closer to prisons were more affected than those located farther away. Finally, I construct a measure by weighting by both industry and trade costs between a given county and all counties with prisons and plot the linear fit with the solid black line. Its slope is also negative, lying in between the other two measures, suggesting that both industry and distance 


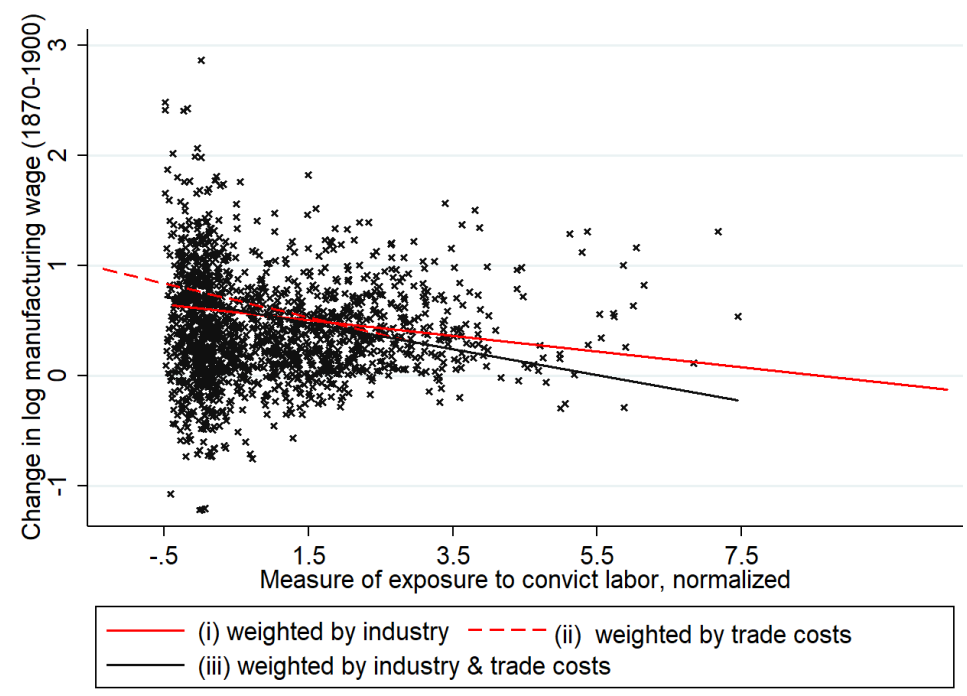

Figure 8. Convict Labor And Changes in MANufaCturing WAGES

Note: Each cross is a county plotted against exposure to prison-made goods in 1886 weighted by industry labor share and trade costs. Black line: measure weighted by industry labor share and trade costs. Red line: measure weighted by industry labor share only. Red dashed line: measure weighted by trade costs only.

(trade costs) were important for the convict-labor shock. ${ }^{25}$

\section{The Effect of Convict Labor on Wages and Firms}

\section{A. Convict Labor and Local Labor Outcomes}

\section{EMPIRICAL SPECIFICATION}

I estimate the effects of the introduction of convict labor in 1870-1886 on local labor markets using the following first-difference regression:

$$
\Delta y_{c, 1880 / 1900}=\alpha+\gamma \Delta C L_{c, 1870 / 1886}+\Pi \Delta X_{c, 1870 / 1880}+\varepsilon_{c},
$$

where the main dependent variable, $\Delta y_{c, 1880 / 1900}$, is the change in log manufacturing wages in county $c$ between 1880 and $1900{ }^{26}$ The main explanatory variable,

\footnotetext{
${ }^{25}$ This measure of a county's exposure to convict labor imposes an assumption that labor mobility across counties is low. If it is wrong, wages should adjust and I should not find any effect on wages or employment.

${ }^{26} \mathrm{My}$ choice of the years for the first differences is dictated by the nature of the historical data. Data for convict labor first appeared in 1886 and was collected because competition with prison-made goods already affected free labor. Thus, I use 1880-1900 instead of 1870-1900 as a time period for the dependent variable to ensure that the explanatory variable is not affected by reverse causality.
} 
$\Delta C L_{c, 1870 / 1886}$, is a change of exposure to convict labor from 1870 to 1886 : as convict labor was virtually nonexistent in 1870 , the change $\left(\Delta C L_{c, 1870 / 1886}\right)$ is actually a level of exposure to convict labor in $1886\left(C L_{c, 1886}\right)$. I define two measures of exposure to convict labor, which I later refer to as "continuous" $\left(C L_{c, t}^{\text {continuous }}\right)$ and "discrete" $\left(C L_{c, t}^{\text {discrete }}\right)$. In the former, I allow all counties to be treated by convict labor. First, I generate the total value of goods produced in prisons by county and industry. Then I weigh that value by the trade costs between those counties with prisons and a given county (in the spirit of Redding and Venables (2004) and Donaldson and Hornbeck (2016)) and by the county's industrial composition (following Topalova (2010) and Kovak (2013)):

$$
C L_{c, 1886}^{\text {continuous }}=\sum_{i \in I}\left(\lambda_{i, c} \times \sum_{k \in K} \frac{\ln (\text { Value of goods produced in prisons }}{i, k, 1886)}\right),
$$

where $i$ is an industry, $I$ is the set of industries (SIC codes 20-39), $k$ is a county with prison, and $K$ is the set of all counties with convict labor in 1886 . Trade $\operatorname{costs}_{c, k}$ are from Donaldson and Hornbeck (2016) and are measured using the calculated county-to-county lowest-cost freight transportation routes in 1870. $\lambda_{i, c}$ is the labor share of industry $i$ in county $c$ in 1870. I assume a linear decay of convict-labor treatment with the cost of trade $(\sigma=1){ }^{27}$

In the discrete measure, only counties that had prisons are considered as treated:

$$
C L_{c, 1886}^{\text {discrete }}=\sum_{i \in I}\left(\lambda_{i, c} \times \ln \left(\text { Value of goods produced in prisons }{ }_{i, c, 1886}\right)\right) .
$$

This measure assigns the value of zero to all nontreated counties (counties without convict labor). I use these two measures as the baseline measures.

$\Delta X_{c, 1870 / 1880}$ is a matrix of changes in control variables. ${ }^{28}$ To prevent posttreatment contamination, I use changes from the time before convict labor output was measured. I add controls for the changes in the average farm value to control for the opportunity cost of working in the agricultural sector, and for the changes in African American and foreign-born population as proxies for changes in job opportunities and crime rates. I also control for the county's longitude and latitude (to control for the clusterization of certain industries in certain locations) and its area (to address the fact that more western counties were larger) ${ }^{29}$ In

\footnotetext{
${ }^{27} \mathrm{My}$ results also hold if I use alternative industry weighing (Table C4 reports the results with 1870 value shares, and with 1880 (labor and value) industry weighting), the value instead of log value of prison-made goods (Table C7), or the alternative iceberg costs (Table C5 explores the sensitivity of the results to other values of $\sigma$ in, and Table C6 shows robustness to using distance (in $\mathrm{km}$ ) between county $c$ and prison $p$ instead of trade costs).

${ }^{28}$ Following Wooldridge (2015), I add the constant as a difference of the intercepts between periods; however, my results are robust to specification without the constant.

${ }^{29} \mathrm{My}$ results are also robust to inclusion of the number of slaves in 1860 , the number of lynchings, lit-
} 
cases where prison sites were situated in places with cheap land with a decreasing wage trend, or if prisons started to produce more goods in a location where wages tended to increase, I directly control for pretreatment changes in the dependent variable. ${ }^{30} \mathrm{I}$ also add a pretreatment level of the dependent variable to address potential mean-reversion. ${ }^{31}$ I also add controls for the changes in market access, and for the pretreatment level of market access, which can both be correlated with the growth rates of manufacturing wages and incarceration: areas experiencing a higher increase in market access may have higher wage-growth rates (Hornbeck and Rotemberg (2018)), and at the same time higher incarceration and crime rates (thus demanding more convict labor to finance the growing penitentiary system). This would cause me underestimate the effect of convict labor. ${ }^{32}$

\section{IDENTIFICATION}

This first-difference model and the set of controls help me to account for most of the plausible sources of endogeneity; however, there are two sources of endogeneity that I cannot control for.

One is the measurement error in the value of prison-made goods. In addition to the classical measurement error that would attenuate my results, I may have upward bias due to under-reporting. Wardens often did not write down in their books all the output that their prisoners produced, and through collusion with the contractor, they artificially decreased the value of goods produced (McKelvey (1934, 1936); Gildemeister (1978)). In many cases, prisons were employing all their prisoners, while on paper some of them were idle, ill/handicapped, or working less than a full day. In addition, no one controlled the working hours of prisoners; thus, potentially, inmates could make more goods than were reported. ${ }^{33}$ However, under-reporting will cause only scaling upward bias and will not affect the significance of point-estimates. Moreover, assuming that every warden reports only a quarter of the true value of prison-made goods, the evaluation of the overall effect of convict labor (e.g., a comparison of counties in the 25th and the

eracy, or the land-inequality (gini) index as proxies for institutional factors that may affect incarceration, and the number of (Protestant) churches as a proxy for the likelihood of employing convicts and being harsh on crime. These variables do not affect the results, and I exclude them from the baseline specification to keep it parsimonious. If (low-skilled) people migrated out due to competition with convicts from the affected counties, it should decrease labor supply and push wages up, making it more difficult for me to find a negative effect. I cannot control for migration in this specification due to the absence of migration data. Later, in Panel B of Table 3, where I study the effect of the federal anti-convict-labor legislation on local-labor-market outcomes, I directly control for migration in the 1930s, but it does not affect my results.

${ }^{30}$ It is equivalent to the specification in the stacked differences. However, I cannot use the latter, as the levels of exposure to convict labor between 1860 and 1870 are approximately equal to zero.

${ }^{31}$ I use the 1870 level $\left(y_{c, 1870}\right)$, because the 1880 level is already influenced by convict labor in 1880 and mechanically correlates with convict labor in 1886.

32 Alternatively, better market access can increase competition and have an adversely affect the wagegrowth rate (Xu (2018)), and can increase crime rates (as the opportunity cost of crime decreases). This would make me overestimate the effect of convict labor.

${ }^{33}$ Since prisoners were coerced to work, they often overworked (Gildemeister (1978), pp. 34-37 and fn. 21-22). Even officially, the maximum workday of a prisoner in 1886 was 11 hours (Department of Labor (1887)). 
75th percentile of exposure to convict labor) won't be affected. Hence, it will be a problem only if there is a differential probability in under-reporting.

My second endogeneity concern is related to the choice of industry by prisons and strategic location of prisons built after convict labor was allowed. In Figure A5, I demonstrate that convict labor was not concentrated in industries or counties that experienced higher growth in wages from 1860 to 1870 . Pre-convictlabor growth in wages also did not correlate with the probability of building a new prison in 1886 (p-value=0.432). However, Hiller (1915) and Gildemeister (1978) pointed out that wardens tend to employ prisoners in industries where unions were maintaining high wages. As I can't control on the unionization that can correlate with convict labor and local labor market outcomes, it can plague my estimates. This would cause a downward bias of my OLS estimates. Overall concerns about omitted-variable bias and measurement error in OLS estimates make the overall direction of bias ambiguous.

To deal with the endogeneity problem, I use an IV estimation. A plausibly exogenous cross-sectional variation comes from the state prisons that existed in 1870, before convict labor was allowed. ${ }^{34}$ Old prisons were built without any thought given to manufacturing goods for profit, and their locations can be considered exogenous, conditional on factors important for their placement. Historians (Lewis (1922) and McKelvey (1936)) and contemporaneous sources (North American Review (1866)) list several criteria that were used to determine prison locations before 1870: (1) proximity to large urban centers; (2) proximity to a railroad or a navigable river; and (3) proximity of materials suitable for the construction of a prison. The high cost to transport prisoners and materials clearly influenced placement of prisons. ${ }^{35}$ Thus, I control for population, urban share, latitude, and longitude in all specifications. ${ }^{36}$

The first stage of the two-stage-least-squares (2SLS) specification is:

$$
C L_{c, 1886}=\tilde{\alpha}+\tilde{\gamma} O P_{c, 1870}+\tilde{\Pi} \Delta X_{c, 1870 / 1880}+\epsilon_{c} .
$$

The second stage can be written as:

\footnotetext{
${ }^{34}$ Under laws allowing convict labor, here I assume laws allowing private contractors to employ prisoners (see Appendix E). E.g., Pennsylvania had allowed noncongregated convict labor since the Eastern Penitentiary in Philadelphia was established; however, legislation allowing creation of the factories and workshops within prison walls started to appear in the 1870s. from 1850 to the 1930

${ }^{35} \mathrm{An}$ example of such thinking by state legislators can be found in Wisconsin, Legislature (1850) (p. 132), where the location of Wisconsin's first prison is discussed. After some discussion, they chose to build it in the north-central woods, where they could source local timber and because nearby rail access to the Great Lakes would help reduce the cost to transport convicts. Similar discussion took place in 1857 in Illinois, when the location for the Joliet Penitentiary was chosen (Illinois State Penitentiary (1857), p. 450).

${ }^{36}$ Table B1 performs a balance test, by comparing counties with and without prisons in 1870, before convict labor was enacted. While the mean population and urban shares are higher for counties with prisons, they are not statistically different from counties without prisons, and statistically the two samples do not differ in any covariate.
} 


$$
\Delta y_{c, 1880 / 1900}=\alpha+\gamma \widehat{C L}_{c, 1886}+\Pi \Delta X_{c, 1870 / 1880}+\varepsilon_{c},
$$

where the instrument measures exposure of each county by the old prisons around

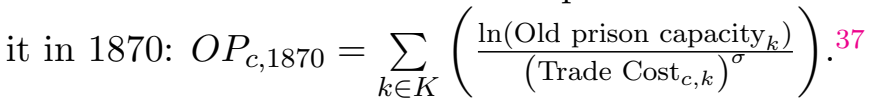

This instrument assumes that the number of convicts in old prisons is a good predictor for the number of convicts in 1886, and the value of goods produced. It also assumes that productivity of prisoners is similar across all manufacturing industries. In Figure 9, I visualize the fact that counties that had more prison capacity before convict labor was imposed also had higher values of prison-made goods in 1886. Panel A shows that several old prisons were closed by 1886 and quite a few new prisons were opened; however, there is strong positive correlation between old prisons' capacities and the total value of prison-made goods in counties that did not close old prisons ("county-compliers"). Panel B presents the first-stage residual plot: the relationship between the endogenous explanatory variable $\left(C L_{c, 1886}\right)$ and the instrument $\left(O P_{c, 1870}\right)$ is strong and linear.
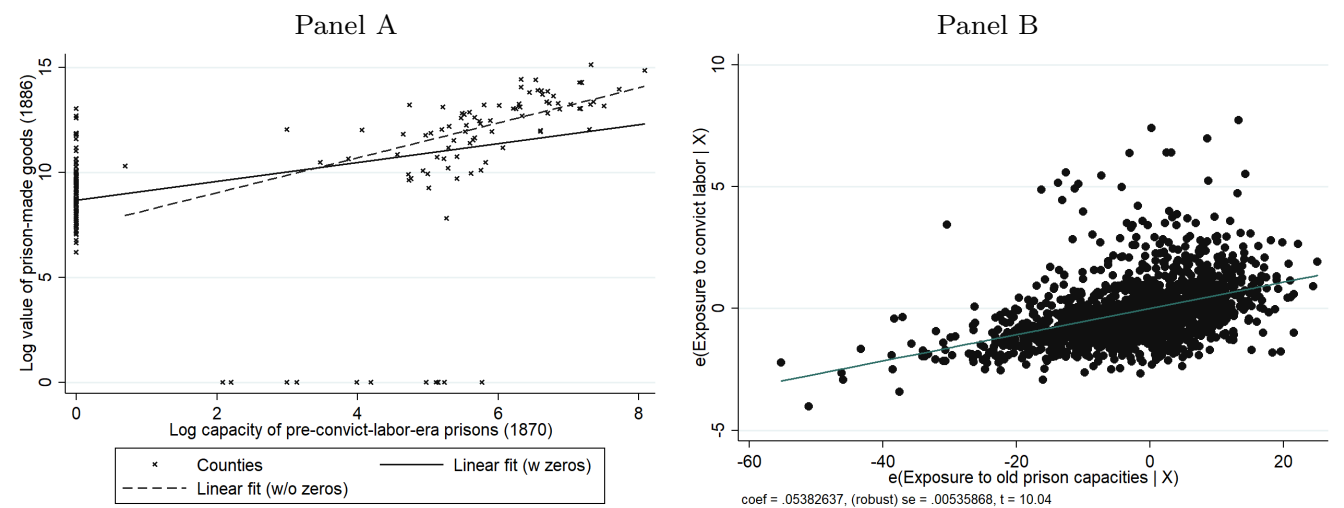

Figure 9. The first stage: Correlation Between the Value of Prison-made goods and the CAPACITIES OF OLD PRISONS, AND THE RESIDUAL PLOT

Note: Panel A contains only counties with prisons. Panel B contains an added-variable plot from the regression specification in Column II of Table 1. Results of the first stage are available in Table 1.

\footnotetext{
${ }^{37} \mathrm{I}$ also assume that $\sigma=1$; however, my results hold if I use $\sigma=0.5$ and 2 (Table C5) or if I use distance-to-prison instead of trade costs (Table C6). I use prison capacities in 1870 instead of using prison capacities in a year just before the state accepted convict-labor legislation in case a prison could expand its capacities in expectation of new convict-labor legislation (if they see that nearby states adopted them early). Nevertheless, my results hold if I use the latest prison capacities before the enactment of convictlabor legislation. I keep prisons in the state of New York even if New York had convict-labor legislation prior to 1870, because they were built due the same demographic considerations as the other old prisons (McKelvey (1936)). All results hold if I omit them. All results are available on request.
} 
The main identification assumption here is the absence of counterfactual trends that correlate with exposure to old prison capacities and labor-market outcomes. While it is not testable, Panel A of Figure 10 shows that exposure to old prison capacities does not correlate with pre-convict-labor growth in manufacturing wages, suggesting that the instrument does not correlate with the pretrends. Further, I address this concern by directly controlling for the pretrends in the dependent variables in the right-hand side of the equation. Because the instrument does not depend on the industrial composition, it eliminates the endogeneity related to the endogenous choice of industries by prisons. I test this assumption in Panel B of Figure 10, where I show an absence of correlation between exposure to old prisons and the value of goods produced in prisons by industry. I also assume that preexisting prisons are uncorrelated with the error term and do not directly affect wages in manufacturing. There are two major sources of the exclusion-restriction violation. First, suppose released prisoners stay in the locations of old prisons, it may increase future crime rates and hinder economic activity. Thus, I control for the changes in Black and foreign-born population to address possible changes in crime rates. In addition, penitentiary historians (e.g., McKelvey (1936)) also noted that most of the ex-prisoners were returning to their counties of residence after the release. Second, if prisons deteriorate human capital of the ex-prisoners, it may also affect future local-labor-market outcomes. However, the number of prisoners in 1870 was too small to affect labor markets, and including changes in literacy rates as control helps me to address this concern.
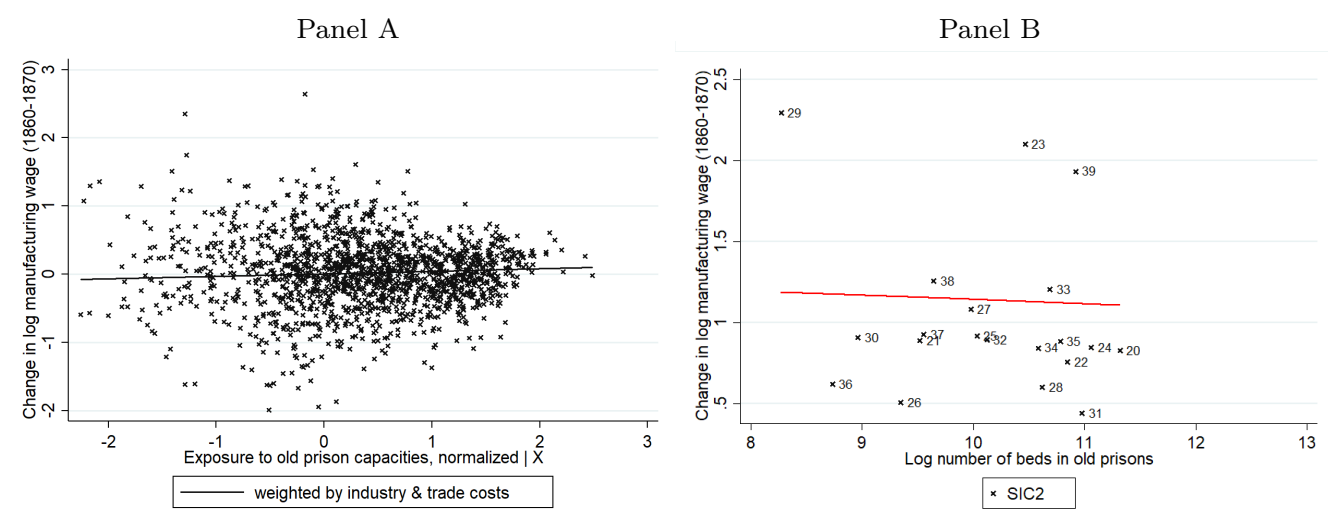

Figure 10. Old PRisons AND the industrial COMPOSITION OF CONVICT LABOR

Note: In Panel A, each cross is a county. In Panel B, each cross is a two-digit SIC code. In panel B, I control for factors that were important for the choice of prison location: population, market access, and latitude and longitude. 


\section{Results}

The results for the continuous specification are presented in Panel A of Table 1. Columns I and II show OLS and 2SLS estimates of the regression of convict labor on changes in log manufacturing wages in 1880-1900. I add controls only for changes in log manufacturing output (to control for vulnerability of the local manufacturing sector) and for population and urban share (as the main determinants of the location of old prisons). Both estimates are significant, and the IV estimate is, approximately, $45 \%$ larger than the OLS one, while the first-stage F-statistics of the excluded instrument is around 83.7. The difference between the county-level convict-labor change in counties at the 25 th and 75 th percentiles is 2 standard deviations. Evaluated using the Column II estimate, a county at the 25th percentile experienced 9.6-percentage-point smaller wage increase (or larger wage decline) than a county at the 75 th percentile over 20 years, or 0.48 percentage points annually.

Columns III to VIII control for various potential confounding factors to check the robustness of the result. Nevertheless, including these controls weakening the first stage but does not change the significance or magnitude of the effect of convict labor. ${ }^{38}$

In Appendix C.C2, I demonstrate that my results also hold if I use a specification with only industry weights, with only trade-cost weights, or with a measure similar to the one in Autor, Dorn and Hanson (2013). As a placebo, in Table C16, I show that convict-labor output in farming had no effects on manufacturing outcomes.

The discrete specification in Panel B yields similar results. This specification also alleviates the concern that distances to prisons (and thus trade costs) correlate with manufacturing outcomes. While all OLS and 2SLS estimates remain significant, all magnitudes experience a slight decrease (compared to the corresponding columns in Panel A). The most plausible explanation for this effect is that the effect of competition with prison-made goods exceeded the boundary of a county, and thus in the discrete specification, I count partially treated counties (close to counties with prisons) as control counties. Thus the differences in wages between them are smaller, and I underestimate the effect of convict labor. ${ }^{39}$

Here, I use the value of goods produced by prisons instead of the number of

\footnotetext{
${ }^{38}$ Market access is accounted for in the explanatory variable and, indirectly, in the instrument, as it uses trade costs between the county and location of all prisons. Despite the fact that specification in Column VIII is very restrictive, the first stage is strong enough. The Anderson-Rubin test's p-value is 0.07. Partial $R^{2}$ is equal to 0.09, in comparison to 0.19 in Column VI. Both are high enough to show that the instrument has explanatory power but not high enough to be afraid that it is similar to the explanatory variable and it suffers from the same endogeneity concerns.

${ }^{39}$ In Appendix B, I discuss the robustness of my results to sample trimming based on a two-stage procedure, where I first find important covariates through LASSO, and then estimate the propensity score and drop $15 \%$ of counties without prisons (control) that are least similar to counties with prisons (treated). In addition, Table C19 shows the robustness of my results to a matching estimation comparing (on observables) counties with prisons to similar counties without prisons. While these results also corroborate my main findings, they are subject to the same issues as the discrete specification, as "control" counties are also partially treated by the nationwide convict-labor shock.
} 
employed prisoners, because the former is prone to a smaller measurement error than the latter. Census enumerators noted that prisons kept good statistics for the value of prison-made goods; however, they often could not provide accurate numbers of prisoners employed on different tasks. However, for completeness, Table C3 contains results for the specification with the number of employed convicts instead of the value of goods produced: all results hold. ${ }^{40}$

Finally, in case convict labor affected states deferentially because of the differences in convict-labor legislation, I allow each state to be on a different intercept. Table $\mathrm{C} 12$ shows that my results are robust even to this very restrictive specification, using an identifying variation from within-state exposure to old prison capacities.

\section{Standard ERrors}

Convict labor was subject to state-level legislation, so I cluster standard errors by state. The number of clusters (41 states) is slightly below the "rule of 42" (Angrist and Pischke (2008)), and I report wild-bootstrapped (Cameron, Gelbach and Miller (2008)) p-values in Table C13. ${ }^{41}$

The continuous measure of exposure to convict labor (equation 2) prompts an additional discussion about clustering standard errors. First, for example, as counties in Maryland can be affected by prisons in Virginia (not subject to Maryland's convict-labor legislation), I also use robust standard errors without clustering by states. Second, I use spatial HAC errors to correct for spatial autocorrelation (Conley $(1999,2010)$ ). Both resulting standard errors are always smaller or similar to those clustered by state, and I choose to report clustered-bystate standard errors as the most conservative (see Appendix C.C4). My results also hold if I use exposure by prisons of that county's state only (Table C8). In such a specification, clustering by state is unambiguously preferable. Nevertheless, this specification is missing a lot of variation in the explanatory variable.

\section{Evidence from the Panel Data}

Here, I use the panel nature of my data to visualize the decay of the convictlabor effect with distance, and to demonstrate robustness of my results.

First, I use an event-study design to show that counties located closer to prisons were more severely affected than those that were farther away. I run a regression of the $\log$ value of goods produced in 1886 in a county $c$ on log wages in manufacturing, controlling only for state and decade fixed effects, and log manufacturing output (see equation C7). The resulting coefficients are presented in Figure 11. The blue line presents a result for counties that had convict labor. The OLS

\footnotetext{
${ }^{40}$ I have the number of employed convicts by industry only for $1886,1923,1932$, and 1940 . Thus, I prefer to use value of goods for the baseline specification to be consistent with the results in Appendix E.

${ }^{41}$ Hansen (2007) finds that Stata's cluster command is reasonably good at correcting for serial correlation in panels, even in a 10 -cluster scenario.
} 
TABle 1-Convict LABOR And MANufaCturing WAGES: Introduction of CONVICT LABOR (1870-1886)

\begin{tabular}{|c|c|c|c|c|c|c|c|c|}
\hline Panel A & $\overline{\mathrm{I}}$ & II & III & IV & $\overline{\mathrm{V}}$ & VI & VII & VIII \\
\hline \multirow[t]{2}{*}{ Outcome (1880-1900): } & \multicolumn{8}{|c|}{$\Delta$ log wage in manufacturing } \\
\hline & OLS & 2 SLS & OLS & 2 SLS & OLS & 2 SLS & OLS & 2 SLS \\
\hline $\begin{array}{l}\text { Exposure to convict labor } \\
\text { (continuous, 1886) }\end{array}$ & $\begin{array}{l}-0.033 \\
(0.008)\end{array}$ & $\begin{array}{l}-0.048 \\
(0.015)\end{array}$ & $\begin{array}{l}-0.016 \\
(0.005)\end{array}$ & $\begin{array}{l}-0.036 \\
(0.018)\end{array}$ & $\begin{array}{l}-0.015 \\
(0.005)\end{array}$ & $\begin{array}{l}-0.033 \\
(0.018)\end{array}$ & $\begin{array}{l}-0.012 \\
(0.005)\end{array}$ & $\begin{array}{l}-0.039 \\
(0.023)\end{array}$ \\
\hline Additional controls & & & $\mathrm{X}$ & $\mathrm{X}$ & $\mathrm{X}$ & $\mathrm{X}$ & $\mathrm{X}$ & $\mathrm{X}$ \\
\hline log wage in manuf., 1870 & & & $\mathrm{X}$ & $\mathrm{X}$ & $\mathrm{X}$ & $\mathrm{X}$ & $\mathrm{X}$ & $\mathrm{X}$ \\
\hline$\Delta$ log wage in manuf., (1860-1870) & & & & & $\mathrm{X}$ & $\mathrm{X}$ & $\mathrm{X}$ & $\mathrm{X}$ \\
\hline MA (1870) \& $\Delta$ MA (1870-1890) & & & & & & & $\mathrm{X}$ & $\mathrm{X}$ \\
\hline First-stage instrument's coefficient & & $\begin{array}{c}0.058 \\
(0.006)\end{array}$ & & $\begin{array}{c}0.054 \\
(0.005)\end{array}$ & & $\begin{array}{c}0.054 \\
(0.005)\end{array}$ & & $\begin{array}{c}0.128 \\
(0.031)\end{array}$ \\
\hline R-squared & 0.09 & 0.08 & 0.23 & 0.22 & 0.23 & 0.23 & 0.23 & 0.22 \\
\hline F-stat excl. inst. & & 83.7 & & 102.2 & & 100.9 & & 17.2 \\
\hline Observations & 1,603 & 1,603 & 1,603 & 1,603 & 1,603 & 1,603 & 1,603 & 1,603 \\
\hline$\overline{\text { Panel B }}$ & I & II & III & IV & $\mathrm{V}$ & VI & VII & VIII \\
\hline \multirow[t]{2}{*}{ Outcome (1880-1900): } & \multicolumn{8}{|c|}{$\Delta$ log wage in manufacturing } \\
\hline & OLS & 2 SLS & OLS & 2 SLS & OLS & $2 \mathrm{SLS}$ & OLS & 2 SLS \\
\hline $\begin{array}{l}\text { Exposure to convict labor } \\
\text { (discrete, 1886) }\end{array}$ & $\begin{array}{l}-0.014 \\
(0.002)\end{array}$ & $\begin{array}{l}-0.021 \\
(0.006)\end{array}$ & $\begin{array}{l}-0.005 \\
(0.002)\end{array}$ & $\begin{array}{l}-0.020 \\
(0.009)\end{array}$ & $\begin{array}{l}-0.005 \\
(0.002)\end{array}$ & $\begin{array}{l}-0.019 \\
(0.009)\end{array}$ & $\begin{array}{l}-0.004 \\
(0.002)\end{array}$ & $\begin{array}{l}-0.007 \\
(0.004)\end{array}$ \\
\hline Additional controls & & & $\mathrm{X}$ & $\mathrm{X}$ & $\mathrm{X}$ & $\mathrm{X}$ & $\mathrm{X}$ & $\mathrm{X}$ \\
\hline log wage in manuf., 1870 & & & $\mathrm{X}$ & $\mathrm{X}$ & $\mathrm{X}$ & $\mathrm{X}$ & $\mathrm{X}$ & $\mathrm{X}$ \\
\hline$\Delta$ log wage in manuf., (1860-1870) & & & & & $\mathrm{X}$ & $\mathrm{X}$ & $\mathrm{X}$ & $\mathrm{X}$ \\
\hline MA (1870) \& $\triangle \mathrm{MA}(1870-1890)$ & & & & & & & $\mathrm{X}$ & $\mathrm{X}$ \\
\hline First-stage instrument's coefficient & & $\begin{array}{c}0.133 \\
(0.019)\end{array}$ & & $\begin{array}{c}0.096 \\
(0.015)\end{array}$ & & $\begin{array}{c}0.095 \\
(0.016)\end{array}$ & & $\begin{array}{c}0.739 \\
(0.078)\end{array}$ \\
\hline R-squared & 0.09 & 0.08 & 0.22 & 0.20 & 0.23 & 0.21 & 0.23 & 0.23 \\
\hline F-stat excl. inst. & & 47.0 & & 38.7 & & 37.3 & & 90.3 \\
\hline Observations & 1,603 & 1,603 & 1,603 & 1,603 & 1,603 & 1,603 & 1,603 & 1,603 \\
\hline
\end{tabular}

Note: Exposure to convict labor is normalized. All columns contain a constant and the following control variables (in changes, 1870-1880): log manufacturing output, log total population, and urban share. Additional controls include changes in share of Black population, share of foreign-born population, log value of farms, and log county's area, latitude, and longitude. Robust clustered-by-state standard errors are in parentheses. Here, I use population weights; however, my results hold if I don't use weights or if I weight by market access. Reduced-form results are shown in Table C1.

coefficient becomes negative and significant as soon as convict-labor laws were enacted, and the effect persisted.

Then I repeat the same regression, but I treat counties adjacent to counties with convict labor. The resulting coefficients are smaller in magnitude than those for counties with a prison (dashed green line). Thus, the effect was smaller in nearby counties. Finally, I show that estimates become even smaller when I use counties adjacent to counties that are adjacent to counties with convict labor (dashed gray line). At the same time, treated counties did not experience any demographic/urban shock that could explain differential effect of convict labor on wages. In Figure C2, I show the absence of a significant effect (and no difference between adjacent counties) of convict labor on population, urbanization, and the share of Black population. 
Figure 11 suggests that the elasticity of the effect of convict labor on log manufacturing wages in 1880 in counties with prisons is equal to 0.02. I find similar results by using firm-level data spanning from 1850 to 1880 from Atack and Bateman (1999) in Appendix C.C8: the elasticity of the effect of convict labor on wages of firms in the same county and industry is equal to 0.014 (Column IV of Table C18).

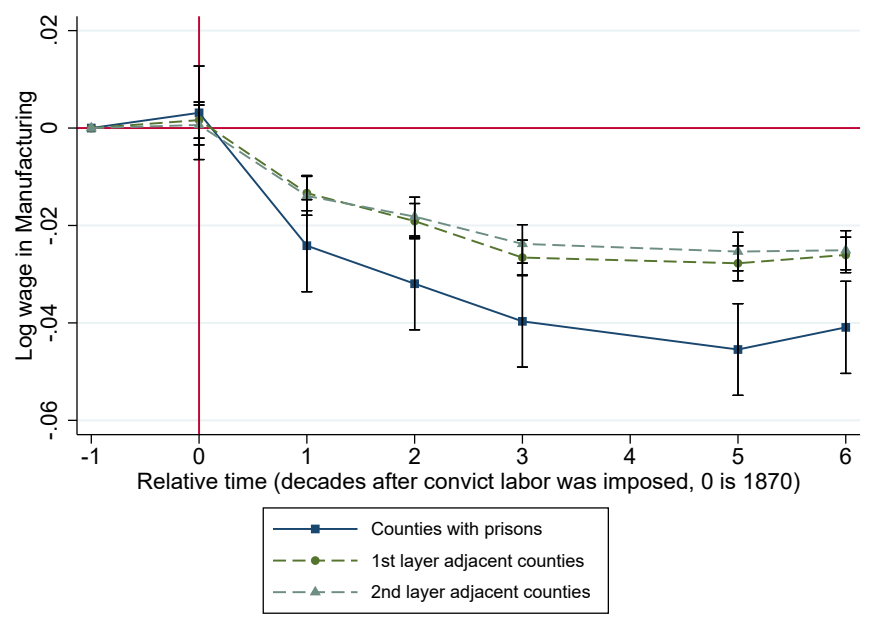

Figure 11. Convict Labor and Manufacturing WAges: Event Study

Note: Each square is the coefficient of the event-study regression of the log wages in manufacturing on the time-invariant log value of convict-labor output in 1886 in a county, interacted with decade dummies. Relative time (in decades) is plotted on the horizontal axis, such as 1880 is counted as 1 — the first decade when convict labor was imposed. Wage data for 1910 is not available. I use state and decade fixed effects, and log manufacturing output in a county as controls. The dark blue line corresponds to a regression where I treat counties that had convict labor in it as treated. The dashed green line treats counties that are adjacent to counties that had prisons. The dashed gray line assumes that counties that are adjacent to counties that are adjacent to prisons as treated. My results hold if I double-count counties that are adjacent to more than one county with a prison. 95\% confidence intervals are depicted.

Second, I further explore the county-decade panel nature of the data in Appendix E. The first benefit of this approach is that I can use not only the exogenous introduction of convict labor but also changes in the intensity of competition with prison-made goods, and the opening/closure of prisons. Second, panel also allows me to use the 1936 federal legislation restricting convict labor to estimate the exogenous shock of the decrease in competition with prison-made goods. Third, the panel dataset allows me to account for time- and county-invariant unobserved heterogeneity and county-specific time trends. Fourth, in comparison with the specification in first-differences, here I use levels to estimate the elasticity of the effect of convict labor on wages.

However, this specification also requires additional identification assumptions when I employ an IV estimation. I use state-level variation in the timing of pas- 
sage of convict-labor laws interacted with the capacity of prisons that existed before convict-labor laws were enacted to construct an instrument for the prevalence of convict labor. Prison production was determined by a prison's warden, and the state legislature can be considered exogenous. Thus, conditional on factors important to the location of the old prisons, the interaction of convict-labor legislation and capacities of old prisons is likely uncorrelated with wardens' activity, choice of prison industries, and possible strategic location of prisons constructed after convict-labor systems were enacted.

Results of this specification support my hypothesis: a county at the 25 th percentile experienced a $1.26 \%$ larger annual manufacturing wage decrease (or a $2 \%$ larger decline in mean log annual wages in manufacturing) than a county at the 75 th percentile. $^{42}$

Because forms of convict labor differed in the North and the South, I analyze subsamples. The overwhelming majority of convicts were employed in manufacturing within Northern prisons; the relatively few convicts in the South were mostly employed in road construction or mining. ${ }^{43}$ Columns $\mathrm{V}-\mathrm{X}$ of Table E2 show that the results are mainly driven by the Northeastern and Midwestern states. For the Southern states, all coefficients remain significant, while the magnitudes of all effects are smaller.

\section{An Alternative Mechanism for the Effect of Convict Labor on WAGes: STRIKEBREAKING}

While convict labor adversely affects manufacturing wages through labor demand, an alternative explanation is possible: it made strikes less efficient. Naidu and Yuchtman (2016) demonstrate that "U.S. government supported employers in limiting strikes' efficacy." I suggest that the institution of convict labor was one of such anti-strike institutions. Using the data from the Weeks Report (1886) (Meyer (2004)), I examine the association between convict labor and strikes to shed light on how convict labor affected manufacturing wages through channels other than reduction of labor demand. Here, I do not make a causal claim, as strikes were endogenous to various factors and the sample of firms is not representative. Nevertheless, these results are informative: Column I of Table C17 shows a strong negative correlation between convict labor in 1886 and the incidence of a strike after 1880. An indicator variable for a firm that experienced competition with prison-made goods in state $s$ in industry $i$ is associated with a 15-percentage-point smaller probability of a strike. In addition, those strikes become less efficient: a convict-labor dummy is associated with a 11-percentagepoint larger probability of workers losing a strike (Column II). This result suggests that convicts were used as strikebreakers, thus making strikes less successful. ${ }^{44}$

\footnotetext{
${ }^{42}$ Based on an IV estimate with the continuous measure of convict labor from Column II of Table E2.

${ }^{43}$ Because the North and the South differed in terms of both local institutions and industrial composition, they adopted different systems of convict labor (Wilson (1933) and McKelvey (1936)).

${ }^{44}$ There is also a positive correlation between the probability of a strike in the years before convictlabor laws were passed and convict labor in 1886 in Column III; however, it is marginally insignificant
} 


\section{Other Local-Labor-Market Outcomes}

In Columns I to IV of Table 2, I report results for continuous and discrete specifications for changes in manufacturing employment share in 1880-1900. Evaluated using the Column II estimate, a county at the 25 th percentile experienced a 5.7percentage-point larger drop in manufacturing employment share than a county at the 75th percentile. Columns V to VIII show the effect of convict labor on changes in labor-force participation. Again using the estimate from Column VI, a county at the 25 th percentile experienced a 2.4-percentage-point larger drop in labor-force participation than a county at the 75 th percentile. ${ }^{45}$

TABle 2 - CONVICT LABOR AND LABOR-MARKet OUTCOMES:

INTRODUCTION OF CONVICT LABOR (1870-1886)

\begin{tabular}{|c|c|c|c|c|c|c|c|c|}
\hline \multirow[t]{3}{*}{$\begin{array}{l}\text { Outcome (1880-1900) } \\
\end{array}$} & \multicolumn{4}{|c|}{ 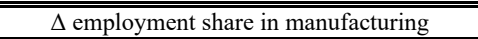 } & \multicolumn{4}{|c|}{$\Delta$ $\Delta$ labor-force participation } \\
\hline & $\mathrm{I}$ & II & III & IV & $\mathrm{V}$ & VI & VII & VIII \\
\hline & OLS & 2 SLS & OLS & $2 \mathrm{SLS}$ & OLS & 2 SLS & OLS & 2 SLS \\
\hline $\begin{array}{l}\text { Exposure to convict labor } \\
\text { (continuous, 1886) }\end{array}$ & $\begin{array}{l}-0.002 \\
(0.002)\end{array}$ & $\begin{array}{l}-0.03 \\
(0.01)\end{array}$ & & & $\begin{array}{l}-0.001 \\
(0.002)\end{array}$ & $\begin{array}{l}-0.011 \\
(0.005)\end{array}$ & & \\
\hline $\begin{array}{l}\text { Exposure to convict labor } \\
\text { (discrete, 1886) }\end{array}$ & & & $\begin{array}{l}-0.003 \\
(0.001)\end{array}$ & $\begin{array}{l}-0.01 \\
(0.00)\end{array}$ & & & $\begin{array}{l}-0.002 \\
(0.001)\end{array}$ & $\begin{array}{l}-0.002 \\
(0.001)\end{array}$ \\
\hline $\begin{array}{l}\text { First-stage instrument's } \\
\text { coefficient }\end{array}$ & & $\begin{array}{c}0.133 \\
(0.019)\end{array}$ & & $\begin{array}{c}0.096 \\
(0.015)\end{array}$ & & $\begin{array}{c}0.095 \\
(0.016)\end{array}$ & & $\begin{array}{c}0.739 \\
(0.078)\end{array}$ \\
\hline R-squared & 0.09 & -0.02 & 0.09 & 0.09 & 0.05 & 0.02 & 0.05 & 0.05 \\
\hline F-stat excl. inst. & & 33.33 & & 73.50 & & 18.15 & & 90.71 \\
\hline Observations & 1,603 & 1,603 & 1,603 & 1,603 & 1,603 & 1,603 & 1,603 & 1,603 \\
\hline
\end{tabular}

Note: Exposure to convict labor is normalized. All columns contain a constant and the following control variables (in changes, 1870-1880): log manufacturing output, log total population, urban share, share of Black population, share of foreign-born population, log value of farms, level and change of log market access (1870), and log county's area, latitude, and longitude. All columns have a corresponding lagged outcome variable (level and changes) as a control. Robust, clustered-by-state standard errors are in parentheses.

The Department of Labor (1925) explicitly argued that in many cases free laborers worked fewer months per year than they were officially employed. Hence, my estimates for manufacturing employment may underestimate the effect of convict labor because I can’t distinguish partially and fully employed people.

(p-value $=0.15)$. The resulting coefficient is a not-well-estimated zero, thus, I can't reject the points raised in Hiller (1915) and Gildemeister (1978), who wrote that at least some wardens used convict labor in industries that had stronger unions. More likely, some wardens did so, but not all of them.

${ }^{45} \mathrm{~A}$ possible extension would be to check effects of convict labor separately for low-skilled workers and high-skilled workers, thus contributing to the literature related to human capital and technological change (e.g., Goldin and Katz (2012)). Magnitudes of the effect should be even larger for low-skilled workers, while high-skilled workers should experience an increase in labor demand when firms would shift to higher-quality goods in an attempt to compete less with prison labor. However, to my knowledge, wage and employment data by skill are not available for that time period. Although, I find that the adverse effect of convict labor is more pronounced for the wages of (low-skilled) child workers than it is for average wages. The results are available on request. 
Using the Weeks Report data, in Column IV of Table C17 I show that workers in affected firms had more slack time throughout the year: a convict-labor dummy is associated with three fewer work weeks per year.

I do not find evidence that convict labor caused unemployment and decreased the labor-force participation rate in the panel specification (Table E3). One plausible explanation is that convict labor may have affected employment only between the time it was introduced and abolished (see Section III.B).

\section{Benchmarking the Effect of Convict Labor}

To gauge the economic magnitude of these effects, I compare the estimated reduction in wages and employment with the observed changes from 1880 to 1900. Here I assume that exposure to prison-made goods affected the absolute level, and not just a relative level, of manufacturing employment, wages, and labor-force participation across U.S. counties. Given the magnitude of convictlabor output (for each manufacturing worker with an average annual wage of $\$ 242$ at least $\$ 18$ per worker of prison-made goods were produced in 1886), it seems plausible that competition with prison-made goods had an absolute impact on U.S. manufacturing.

My specifications use a normalized explanatory variable; however, for the purpose of evaluating the effect of the introduction of convict labor, I use estimates from a non-normalized explanatory variable. From 1870 to 1886, the log of value of prison-made goods grew by $421.8{ }^{46}$ Applying this value to the non-normalized estimate for the continuous specification in Column VIII of Table $1(-0.00024)$, I calculate that 20 years of exposure to convict labor decreased growth in manufacturing wages by 10 percentage points, or 0.5 percentage points per year. Wages in manufacturing were growing at that time 2 percentage points annually on average; thus, in the absence of convict labor, manufacturing wage growth would be $24.8 \%$ higher.

Similarly, I calculate what the labor-force participation and manufacturing employment shares would be without exposure to convict labor. From 1880 to 1900 labor-force participation grew by 2.1 percentage points; however, using the coefficient from Column IV (-0.018), I find that exposure to convict labor caused a differential decrease in labor-force participation of 0.2 percentage points. The manufacturing employment share grew by 3.0 percentage points, and using the coefficient from Column VI $(-0.049)$, I calculate that exposure to convict labor decreased growth in the manufacturing employment share by 0.6 percentage points. Thus without convict labor, the labor-force participation and manufacturing employment shares would be $20.3 \%$ and $16.9 \%$ larger, respectively. ${ }^{47}$

\footnotetext{
${ }^{46}$ To make growth in the value of prison-made goods comparable to my measure, I compute it as $\sum_{k \in K} \sum_{i \in I}\left(\ln \left(\right.\right.$ value of goods produces $\left.\left._{i, k}\right)\right) /($ mean trade costs $\times$ \#industries $)$. For comparison, the mean value of the explanatory variable is 450.8 .

${ }^{47}$ Another way to indicate the significance of the introduction of convict labor is to compare its effects to those of the China shock (Autor et al. (2013)). Comparing two counties, one at the 25th percentile
} 


\section{B. Heterogeneous Effects of Convict Labor on Female-Labor-Market Outcomes}

\section{Convict Labor in Female-Labor-Intensive Industries}

Firms affected by competition with prison labor were trying to decrease wages to keep up with prison-made goods, and thus the well-being of low-skilled laborers deteriorated. The competition was most intense for unskilled women. The number of female-labor-intensive industries was limited, and prisons were heavily involved in all of them (see Figure 3). The following quote (Department of Labor (1925), pp. 112-113) describes how the demand for low-skilled laborers was affected by this competition:

"We have been forced to go into higher line. One of the worst elements in the situation is the difficulty in training girls. When we had a large output of lower grade goods we put new hands on them. They could turn out the dresses rapidly, make better money and have enough showing in quality to hold their interest until they were expert enough to do the fancier garments. Now we cannot afford to produce enough of this class of merchandise for training purposes. Instead, men are being trained to do it in prisons. They can never use this training after their discharge as this kind of work is wholly monopolized by women. A new girl put on the higher grade stuff in the factory can not make more than one garment a day and then it is not well done and she is under severe nervous strain. The girls become discouraged and quit and we have it all over again. We have girls crying around here all the time because they can not handle the only work we have for them. ... We have closed one plant with 40 machines, employing 50 girls, where we produced only the cheap goods. It was closed two years ago and we do not expect to operate it again. Prison labor has shot this industry to pieces."

The garment and shoemaking industries were hammered the hardest by prisonmade goods. The share of the value of prison-made products in these industries was around $45 \%$ in 1886 and reached $75 \%$ by 1932 . Two reasons distinguish why those industries were overcome by convict labor: the relative simplicity of the production process and the relative weakness of women's labor rights. Male laborers and their unions fought fiercely against employment of convicts in their industries (Gildemeister (1978)), but women could not fight back against prison labor in the same way. Thus over time prisons shifted their production toward less protected female-labor-intensive industries. And later, as the state-use system came into vogue (again, due to anti-convict-labor campaigns), prisons could sell

and the other at the 75th percentile of exposure to convict labor, the more exposed county suffered $63 \%$ of the size of the China shock in terms of manufacturing employment, $143 \%$ in terms of labor-force participation, and $52 \%$ in terms of log mean manufacturing wages. (For wages, I use the estimate from Column II of Table E2 to be comparable with Autor et al. (2013) in terms of the dependent variable). 
their goods only to state or federal agencies (e.g., the Army), which had a large demand for clothes.

Labor demand decreased in the apparel and shoemaking industries, but whereas men could move to another industry, women had fewer alternatives. ${ }^{48}$ I expect that wages and labor-force participation decreased more for women than for men, because there were few industries were women could find a job, and in most of them they competed with prison-made goods.

\section{The Effect of Convict Labor on Female-Labor-Market Outcomes}

Data by gender are available only for 1890 and 1900 (from Haines (2004)). Hence, I use changes in log manufacturing wages from 1890 to $1900 .{ }^{49}$ It is hard to argue for the absence of pretrends or mean-reversal of the dependent variable due to data limitations. Thus, I provide OLS results with strong suggestive correlation; however, as the IV coefficients in the previous section were larger than OLS, OLS should yield more conservative estimates.

As data on female wages are also available from the 1940 and 1950 U.S. population censi, I use another plausible exogenous shock of convict labor. Enactment of federal anti-convict-labor legislation decreased the volume of prison-made goods, which allows me to estimate the effect of the demise of convict labor on rebounding female and male wages. In 1936, two federal laws (the Ashurst-Sumners and the Walsh-Healey Public Contracts Acts) were enacted to prohibit any interstate trade with prison-made goods and to prohibit any contracts with private contractors. While convict labor was abolished only in 1941, by President Roosevelt's Circular 3591, most of the prisons in 1940 produced significantly fewer goods for sale than in 1932. Thus, I use the fall in convict-labor output between 1932 and $1940\left(\Delta C L_{c, 1932 / 1940}\right)$ due to the anti-convict-labor legislature in 1936 on the changes in wages and labor-force participation between 1940 and 1950 - they should bounce back after distortion is removed (e.g., Blanchard and Katz (1992) and Naidu and Yuchtman (2013)). ${ }^{50}$

Results for the continuous and discrete specifications are presented in Table 3. Each column contain results of two separate regressions: one with the outcome for women, and the other (shaded in gray) for men. The table also contains p-

\footnotetext{
${ }^{48}$ In many cases, the situation was exacerbated on account of minimum-wage laws pertaining for women (Department of Labor (1925), p. 110): "Under our [Illinois] minimum wage laws we must pay a beginner $\$ 9$ per week. She earns about $\$ 4$ the first week. Instead of the $\$ 1$ we figure for labor cost, her work cost us $\$ 1.50$. It takes four weeks before she earns what she is paid and she never makes up the difference because she goes onto piece rates and is paid for what she does. The prison has no labor laws and under their contracts, the amount the contractor pays is reduced in proportion if the output does not measure up to the contract terms." State-level minimum-wage laws related to women, children, and Blacks started to appeared in the early 20th century, long before the first federal minimum-wage laws (Thies (1990)). Their effects on labor-force participation, and on women-men and Black-White wage gaps, is an important topic for future study.

${ }^{49}$ Dependent variables for manufacturing employment and labor-force participation are constructed the same way as in Table 1. As they were constructed using IPUMS, data for 1890 are not available.

${ }^{50}$ In this specification, the data allow me to control for the migration. However, migration does not affect my results.
} 
values of the test for whether the differences between point-estimates for men and women are statistically significant.

TABle 3 - Heterogeneous EFFECTS OF CONVICT LABOR ON FEMALE AND MALE LABOR-MARKET OUTCOMES

\begin{tabular}{|c|c|c|c|c|c|c|c|}
\hline \multirow[t]{2}{*}{ 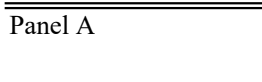 } & & \multicolumn{6}{|c|}{ Introduction of convict labor (1870-1886) } \\
\hline & & $\mathrm{I}$ & II & III & IV & $\mathrm{V}$ & $\mathrm{VI}$ \\
\hline Outcome: & & \multicolumn{2}{|c|}{$\begin{array}{l}\Delta \text { log wage in } \\
\text { manufacturing }\end{array}$} & \multicolumn{2}{|c|}{$\begin{array}{l}\Delta \text { labor-force } \\
\text { participation }\end{array}$} & \multicolumn{2}{|c|}{$\begin{array}{l}\Delta \text { employment share in } \\
\text { manufacturing }\end{array}$} \\
\hline \multirow[t]{2}{*}{$\begin{array}{l}\text { Exp. to convict labor } \\
\text { (continuous, 1886) }\end{array}$} & Female & $\begin{array}{l}-0.257 \\
(0.097)\end{array}$ & & $\begin{array}{l}-0.027 \\
(0.007)\end{array}$ & & $\begin{array}{l}-0.072 \\
(0.018)\end{array}$ & \\
\hline & Male & $\begin{array}{l}-0.159 \\
(0.032)\end{array}$ & & $\begin{array}{l}-0.042 \\
(0.009)\end{array}$ & & $\begin{array}{l}-0.069 \\
(0.012)\end{array}$ & \\
\hline \multirow[t]{2}{*}{$\begin{array}{l}\text { Exp. to convict labor } \\
\text { (discrete, 1886) }\end{array}$} & Female & & $\begin{array}{l}-0.050 \\
(0.018)\end{array}$ & & $\begin{array}{l}-0.005 \\
(0.001)\end{array}$ & & $\begin{array}{l}-0.014 \\
(0.003)\end{array}$ \\
\hline & Male & & $\begin{array}{l}-0.031 \\
(0.004)\end{array}$ & & $\begin{array}{l}-0.008 \\
(0.002)\end{array}$ & & $\begin{array}{l}-0.014 \\
(0.001)\end{array}$ \\
\hline$\gamma_{\text {Male }}-\gamma_{\text {Female }}=0, p$-value & & 0.00 & 0.06 & 0.02 & 0.00 & 0.07 & 0.83 \\
\hline \multirow[t]{2}{*}{ Panel B } & & \multicolumn{6}{|c|}{ ב AS and WH public contracts acts (1936) } \\
\hline & & $\mathrm{I}$ & II & III & IV & $\mathrm{V}$ & $\mathrm{VI}$ \\
\hline \multirow[t]{2}{*}{$\begin{array}{l}\Delta \text { exp. to convict labor } \\
\text { (continuous, 1932/40) }\end{array}$} & Female & $\begin{array}{c}0.088 \\
(0.021)\end{array}$ & & $\begin{array}{c}0.018 \\
(0.004)\end{array}$ & & $\begin{array}{l}-0.008 \\
(0.005)\end{array}$ & \\
\hline & Male & $\begin{array}{c}0.044 \\
(0.019)\end{array}$ & & $\begin{array}{c}0.021 \\
(0.005)\end{array}$ & & $\begin{array}{l}-0.001 \\
(0.004)\end{array}$ & \\
\hline \multirow[t]{2}{*}{$\begin{array}{l}\Delta \text { exp. to convict labor } \\
\text { (discrete, 1932/40) }\end{array}$} & Female & & $\begin{array}{c}0.010 \\
(0.006)\end{array}$ & & $\begin{array}{l}-0.001 \\
(0.001)\end{array}$ & & $\begin{array}{l}-0.003 \\
(0.002)\end{array}$ \\
\hline & Male & & $\begin{array}{c}0.010 \\
(0.005)\end{array}$ & & $\begin{array}{l}-0.001 \\
(0.002)\end{array}$ & & $\begin{array}{c}0.000 \\
(0.001)\end{array}$ \\
\hline$\gamma_{\text {Male }}-\gamma_{\text {Female }}=0, p$-value & & 0.53 & 0.41 & 0.4 & 0.51 & 0.45 & 0.20 \\
\hline
\end{tabular}

Note: Both values of exposure to convict labor are normalized. Each row contains the results from two different regressions: one for outcomes for women, and one for outcomes for men. Coefficients in Panel $\mathrm{B}$ are multiplied by -1 to show the reduction in convict-labor output. All columns contain OLS in first differences. All columns contain a constant. The following variables are used as controls (in changes): $\log$ of total population, urban share, share of Black population, share of women, share of foreign-born population, log of manufacturing output, log value of farms, log of market access (the change and the base level of 1870), and log county's area, latitude, and longitude. Robust, clustered-by-state standard errors are in parentheses.

In Panel A, I study the shock of the introduction of convict labor. The estimate for women in Column I implies that a county facing a one-standard-deviation larger increase in exposure to convict labor experienced an 11.9-percentage-point smaller female-manufacturing-wage increase relative to other counties. The estimate for the manufacturing wages of men in Column I is 3.8 times smaller in magnitude than the one for women, and the difference is statistically significant at the $99 \%$ level. Columns III and IV show an adverse effect on labor-force participation of both men and women. One standard deviation in convict-labor output decreased labor-force participation by 0.5 percentage points for women, and by 0.9 percentage points for men, and the difference of the effect between genders 
is statistically significant: labor-force participation decreased more for men than for women. This may partially explain the fact that women's wages experienced slower growth than men's wages: the labor supply of men adjusted and pushed wages upward. I find similar results for changes in the manufacturing employment share in Column V.

In Panel B, I show the growth of wages and labor-force shares after the enactment of anti-convict-labor legislation in 1936. Estimates for the wage effect are comparable in magnitude; however, the effect of the anti-convict-labor legislation is quite large. The difference between the county-level convict-labor change in counties at the 25 th and 75 th percentiles was 0.70 standard deviations. Thus, a county at the 75 th percentile experienced a 6.2-(3.1)-percentage-point larger female (male) wage increase than a county at the 25 th percentile. However, malefemale estimates in both columns do not differ statistically from each other. The effect on labor-force participation is only significant for the continuous measure: as transportation costs had decreased substantively by the 1930s, the discrete measure is less informative, as the convict-labor shock became a nationwide, rather than a local phenomenon. I find no evidence of an increase in the manufacturing employment share after convict labor was abolished (Columns V and VI).

Thus, competition with prison-made goods had a larger effect on women's wages, at least during the height of the convict-labor era. Moreover, as convicts remained employed in the clothing industry under the state-use system, women's wages did not fully adjust; thus, in Panel B, I don't find a statistically significant difference in wage estimates. ${ }^{51}$ Finally, in Table C20, I show that the effect of convict labor was driven mostly by Northern states.

\section{Convict Labor and Technology Adoption}

\section{Factual Records}

As competition with prison-made goods was tough, and despite the decrease in wages, firms could not employ free laborers for (near) zero wages. ${ }^{52}$ Some firms had to close, partially or entirely; some survived.

However, prisons produced mostly low-quality goods, so high-end markets were less affected. Thus, firms could "innovate away" from competition with prisonmade goods. The first option was to switch to production of high-quality goods ("We are trying to meet the situation by producing a better garment that will command a higher price," and "We have found it impossible to compete in price

\footnotetext{
${ }^{51}$ The output of prison-made goods increased in the clothing industry under the state-use system from 1932 to 1940 . This increase was most likely driven by the increase in military contracts, as WWII had already started.

${ }^{52}$ In addition, states did not tax prisons and often bought new equipment for the prison using taxpayer money. Prisons were exempt from paying federal, state, county, and municipal taxes — " a prison plant pays freight, and it may pay insurance, but its books show no payment for interest, depreciation, or carrying charges. These costs exist, nevertheless, and become a burden to the taxpayers" (Sharkey and Patterson (1933)).
} 
with prison-made stoves. Our only method is to produce a higher grade article"), or buy higher-quality materials that require less labor input ("When poorer material or less trimming is used, more work is done"). The second option was to improve their technology by making it less labor-intensive to create the same type of good more cheaply ( "We have put in every modern machinery and process that we know of to produce our goods at a minimum cost") or with better quality ("We have to be constantly producing new styles and each new style makes additional expense"). ${ }^{53}$

Here, I show that counties more affected by competition with prison-made goods have higher patenting in affected industries. They also have a higher capital-labor ratio, as well as a higher ratio of return-to-capital to return-to-labor. However, the increase in capital-labor ratio is driven not only by the technology adoption but also by the changes in industrial composition (through the death of laborintensive firms). In addition, firms in affected industries and locations shifted to more capital-intensive technologies and improved their technological frontier (Caselli and Coleman (2006)).

\section{Patenting}

I start by replicating the baseline specification from Section A.1, to evaluate the effect of the introduction of convict labor on patenting. ${ }^{54}$ The dependent variable here is the difference between the number of registered patents in the decades of 1890-1900 and 1870-1880. ${ }^{55}$

My results are presented in Table $4 .{ }^{56}$ Columns I to IV estimate the effect of convict labor on patenting in affected industries. Columns I and II contain OLS and IV coefficients for a continuous measure of convict labor: both are positive and significant. Using the coefficient from Column II and comparing a county at the 25th percentile of exposure to convict labor and a county at the 75th percentile, the more exposed county would have seen 84 more patents issued in competing industries in a decade (with a mean of 85 patents in 1890), or a 0.58 standard-deviation increase in the dependent variable. The discrete measure of convict labor (Columns III and IV) yield similar results. These results speak to Hanlon (2015), who found that the number of patents increased in certain industries related to processing of Indian cotton as a reaction to the decrease in supply of U.S. cotton during the Civil War. ${ }^{57}$ My results are also in line with

\footnotetext{
${ }^{53}$ Department of Labor (1925), pp. 111-113.

${ }^{54}$ In addition to the set of controls from Table 1, I also control for the changes in capital and number of manufacturing firms, and for changes in farm output, as some patents are related to agricultural implements. All robustness checks that I perform in Section A.1 also hold for this section. These results are available on request.

${ }^{55}$ Historical patent data are from Petralia, Balland and Rigby (2016). The dependent variable measures differences between the number of patents registered in 1890 to 1900 versus in 1870 to 1880 . I use differences between the number of patents accumulated in ten years because some counties have very few patents registered annually. Thus, I also use the number of patents instead of log; however, my results hold if I use change in logs of patents.

${ }^{56}$ Table $\mathrm{C} 2$ contains the reduced-form results.

${ }^{57}$ Previous studies (Newell, Jaffe and Stavins (1999), Popp (2002), and Aghion et al. (2016)) used
} 
TABle 4-CONVICT LABOR AND PATENTING: InTRODUCTION OF CONVICT LABOR

\begin{tabular}{|c|c|c|c|c|c|c|c|c|}
\hline \multirow[t]{3}{*}{ Outcome (1880-1900) } & \multicolumn{4}{|c|}{$\Delta$ patents in competing industries } & \multicolumn{4}{|c|}{$\Delta$ patents in noncompeting industries } \\
\hline & $\mathrm{I}$ & II & III & IV & $\mathrm{V}$ & VI & VII & VIII \\
\hline & OLS & 2SLS & OLS & $2 \mathrm{SLS}$ & OLS & 2SLS & OLS & 2SLS \\
\hline $\begin{array}{l}\text { Exposure to convict labor } \\
\text { (continuous, 1886) }\end{array}$ & $\begin{array}{c}37.81 \\
(15.24)\end{array}$ & $\begin{array}{c}80.28 \\
(32.68)\end{array}$ & & & $\begin{array}{l}-15.18 \\
(11.67)\end{array}$ & $\begin{array}{c}-8.40 \\
(23.280)\end{array}$ & & \\
\hline $\begin{array}{l}\text { Exposure to convict labor } \\
\text { (discrete, 1886) }\end{array}$ & & & $\begin{array}{c}32.39 \\
(11.92)\end{array}$ & $\begin{array}{c}82.70 \\
(33.56)\end{array}$ & & & $\begin{array}{c}-4.64 \\
(12.26)\end{array}$ & $\begin{array}{c}-8.93 \\
(21.20)\end{array}$ \\
\hline $\begin{array}{l}\text { First-stage instrument's } \\
\text { coefficient }\end{array}$ & & $\begin{array}{c}0.05 \\
(0.004)\end{array}$ & & $\begin{array}{c}0.05 \\
(0.008)\end{array}$ & & $\begin{array}{c}0.05 \\
(0.004)\end{array}$ & & $\begin{array}{c}0.06 \\
(0.008)\end{array}$ \\
\hline R-squared & 0.950 & 0.95 & 0.950 & 0.95 & 0.911 & 0.91 & 0.910 & 0.91 \\
\hline F-stat excl. inst. & & 160.8 & & 33.0 & & 165.6 & & 47.7 \\
\hline Observations & 1,603 & 1,603 & 1,603 & 1,603 & 1,603 & 1,603 & 1,603 & 1,603 \\
\hline
\end{tabular}

Note: Both values of exposure to convict labor are normalized. All columns contain a constant. The following variables are used as controls (in changes): log of total population, urban share, share of Black population, share of foreign-born population, log of manufacturing output, log of value of farm products, log of market access (the change and 1870 base level), and log county's area, latitude, and longitude. All columns have a corresponding lagged outcome variable (level and changes) as a control. Robust, clustered-by-state standard errors are in parentheses.

findings in Zhang (2018), who demonstrated that U.S. firms reacted similarly to the competition with Chinese import. ${ }^{58}$

Columns V to VIII contain a falsification test: I show no effect of convict labor on patents in industries that did not compete with prisons, supporting the hypothesis that patenting was a reaction to competition with prison-made goods. I find similar results for the effects of convict labor on patenting in the panel specification in Appendix F.

\section{Technology Adoption}

Table 5 supports evidence of capital-biased changes in industrial composition. Columns I to IV show that exposure to convict labor increased the average capitallabor ratio. Comparing a county at the 25th percentile of exposure to convict labor versus a county at the 75 th percentile and using the estimate from Column II, the more exposed county would have experienced an increase in capital-labor ratio equal to $18 \%$ of its standard deviation. These results are in line with the historical records quoted above, suggesting that convict labor mostly affected firms that were producing low-quality goods, which could be replaced by low-skilled laborers with the help of necessary machinery, while firms producing higher-grade goods were less likely to suffer (for example, the Amish shops in Holmes and

energy price shocks as a driver of energy-saving technological progress. My findings, however, span a longer time period than previous studies, and my identification comes from competition with prison labor rather than input-factor price shocks.

${ }^{58}$ Here, I contribute to the discussion about whether demand shocks caused by import competition affect firms' patenting and R\&D decisions (Autor et al. (2016) and Bloom, Draca and Van Reenen $(2016))$. 
Stevens (2014)). ${ }^{59}$

TABle 5-Convict LABor And TEChNOLOGY Adoption: Introduction of CONVICT LABor

\begin{tabular}{lcccccccc}
\hline \hline Outcome (1880-1900) & \multicolumn{3}{c}{$\Delta$ capital-labor ratio } & \multicolumn{4}{c}{$\Delta(\mathrm{r} / \mathrm{w})$} \\
\cline { 2 - 8 } & I & II & III & IV & V & VI & VII & VIII \\
\cline { 2 - 8 } & OLS & 2SLS & OLS & 2SLS & OLS & 2SLS & OLS & 2SLS \\
\cline { 2 - 8 } $\begin{array}{l}\text { Exposure to convict labor } \\
\text { (continuous, 1886) }\end{array}$ & 28.89 & 100.52 & & & 0.004 & 0.046 & & \\
Exposure to convict labor & $(13.412)$ & $(52.898)$ & & & $(0.009)$ & $(0.022)$ & & \\
(discrete, 1886) & & & 31.43 & 38.07 & & & 0.004 & 0.016 \\
First-stage instrument's & & & $(12.09)$ & $(20.00)$ & & & $(0.003)$ & $(0.007)$ \\
coefficient & & & & 0.08 & & 0.07 & & 0.21 \\
R-squared & $(0.009)$ & & $(0.028)$ & & $(0.009)$ & & $(0.028)$ \\
F-stat excl. inst. & 0.041 & 0.03 & 0.052 & 0.05 & 0.209 & 0.18 & 0.210 & 0.19 \\
Observations & & 66.5 & & 47.0 & & 61.4 & & 58.9 \\
\hline \hline
\end{tabular}

Note: Both values of exposure to convict labor are normalized. All columns contain a constant. The following variables are used as controls (in changes): log of total population, urban share, share of Black population, share of foreign-born population, log of manufacturing output, log of value of farm products, log of market access (the change and 1870 base level), and log county's area, latitude, and longitude. All columns have a corresponding lagged outcome variable (level and changes) as a control. Robust, clustered-by-state standard errors are in parentheses.

The increase in aggregate capital-labor ratio may indicate not only directed technological change because of patenting and innovation aimed to increase quality of the products or their costs but also a switch from labor-intensive technologies to capital-intensive ones because firms could not compete with prisons in terms of labor costs. To test this hypothesis, in the vein of Acemoğlu (2002) and Acemoğlu and Autor (2011) (who studied the returns-to-skills/college premium), I show in Columns V to VIII that counties more exposed to competition with prison-made goods experienced an increase in returns-to-capital relative to returns-to-labor $(r / w)$. Using the IV coefficient and comparing a county at the 25 th percentile of exposure to convict labor versus a county at the 75 th percentile, the more exposed one would have experienced a 0.48 -percentage-point increase in returns-to-capital to returns-to-labor ratio annually.

Another piece of evidence suggesting that the aggregate increase in capitallabor ratio was driven by switching to technologies that allow them to save on labor comes from the Weeks Report. Column V of Table C17 shows that firms in affected states and industries experienced a 16.4-percentage-point increase in probability of adopting new machinery (n.b., that this sample consists of firms that survived convict labor). Moreover, that machinery was intended to save on labor costs. Using the question of whether the "firm indicates adoption of

\footnotetext{
${ }^{59}$ This result also speaks to Hornbeck and Naidu (2014), who found that counties that experienced higher out-migration of Black population after the Great Mississippi Flood of 1927 increased their capital intensity relative to counties less affected by the flood, and to Clemens, Lewis and Postel (2018), who found that Mexican Bracero exclusion induced adoption of less labor-intensive technologies in more affected states.
} 
a substantial amount of labor-saving machinery" in Column VI of Table C17, I find that, among those firms that adopted new machinery, the exposure to convict labor is associated with a 70-percentage-point increase in the probability of adopting labor-efficient machinery. Thus, at least partially, the increase in capital-labor ratio can be explained by innovation and technology adoption intended to decrease the costs of production, to increase the quality of goods, or to substitute labor with machinery.

My findings suggest that convict labor boosted technology adoption by forcing firms to invent or adopt new technologies that could make them more competitive. However, the increase in average capital-labor ratio can also be explained by the decrease in the share of labor-intensive firms due to competition. I unveil this mechanism using firm-level data from Atack and Bateman (1999). Table C21 shows that a $10 \%$ increase in convict-labor output is associated with a small $0.1 \%$ decrease in the share of firms in that industry. In addition, I find that convict-labor output is positively associated with an average capital per firm and capital-labor ratio in affected industries. These findings suggest that capital labor increased not only because firms in affected industries shifted to better machinery to compete with prison labor but also because more labor-intensive firms died out, thus changing the industrial composition in their states and counties. ${ }^{60}$

Thus, convict labor mostly affected firms that were producing low-quality goods, which could be replaced by low-skilled laborers with the help of necessary machinery, while firms producing higher-grade goods were less likely to suffer. Highly labor-intensive firms in affected industries did not survive. Moreover, because surviving firms had to switch their production line to better-quality goods that competed less with prison products, they became more capital-intensive, or they substituted their low-skilled laborers with capital. At the same time, some firms (especially in unaffected industries) could benefit from lower wages and increase labor relative to capital. However, as I find a positive effect of convict labor on aggregate county-level capital-labor ratio, its effect is smaller than the capitallabor increase due to technology adoption and the death of labor-intensive firms, and the true positive effect on technology adoption is probably underestimated.

\section{The Shifting Technological Frontier}

The increase in patenting and the shift to more capital-intensive technologies was capital-biased. Using methodology developed in Caselli and Coleman (2006), I assume that there is a trade-off between technologies favoring productivity of capital and productivity of labor, and that the same output can be achieved by choosing various combinations of both values. The output is maximized if the chosen productivity of labor and capital are on the technological frontier - the "budget constraint" for firms' productivity choice set.

\footnotetext{
${ }^{60} \mathrm{My}$ findings are consistent with Holmes and Stevens (2014) and Zhang (2018), who found that, in the context of the China shock, firms that relied on low-skilled, labor-intensive production suffered more than those that did not, and that small firms were more likely to exit.
} 
Firms located in counties affected by competition (in the same industry) with prison-made goods invested in technologies associated with the increase in productivity of capital, and they disinvested in the technologies that improve productivity of labor. At the same time, firms located far from the competition with prison-made goods experienced few changes. I provide an example in Figure 12.
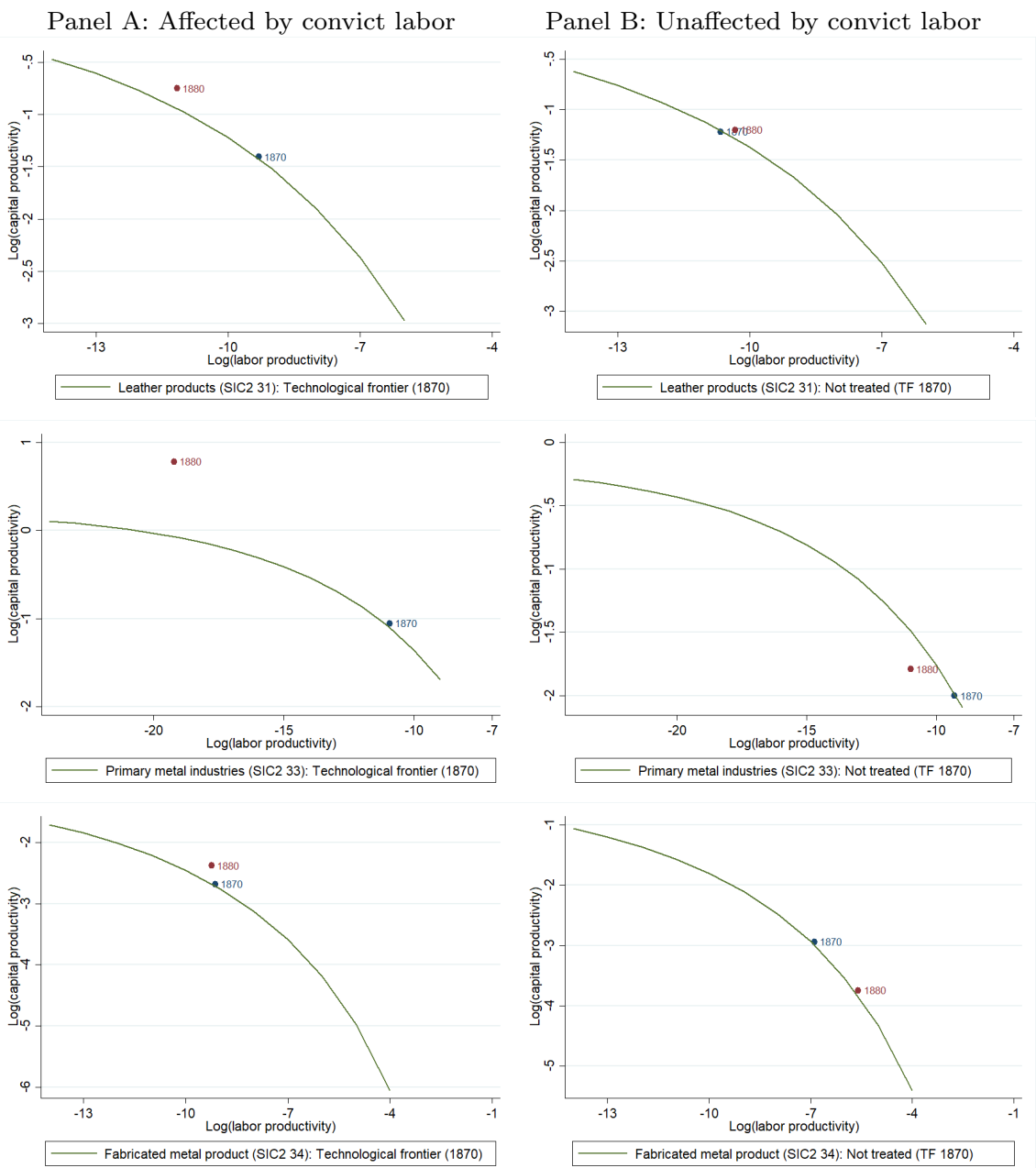

Figure 12. Technological frontier in Selected industries: Affected vs. unaffected firms

On the left side, I depict the technological frontier for metallurgy firms in 1870 located in areas that were subject to high competition with prison-made goods in 1886. On the horizontal axis, I depict the log of productivity of labor, and I plot the $\log$ of capital productivity on the vertical axis. Clearly, after convict labor laws were enacted, affected firms shifted to more capital-intensive technologies. 
Moreover, the technological frontier of affected firms moved slightly upward. On the right side, I show firms in the metallurgy industry that were not affected by the competition. Their capital and labor productivity did not change much from 1870 to $1880 .^{61}$

Overall, the technology-adoption hypothesis is confirmed: counties more exposed to competition from prison-made goods either adopted existing technologies or contributed to new technologies, resulting in substitution of labor with capital. Convict labor boosted technology adoption by forcing firms to invent or adopt new technologies that could make them more competitive.

\section{Discussion of the Contemporary U.S. Convict-Labor System and Concluding Remarks}

Convict labor has always been a controversial topic riven with acrimony. New England settlers wanted to remedy the supposed moral failings of criminals by forcing them to perform hard labor, and today its proponents argue that in-prison labor creates skills needed for after-release employment and saves the state money. While convict labor may reduce budgetary burdens on state and federal governments (Lynch and Sabol (2000)), and may help (or not) rehabilitate prisoners and their future employment opportunities (Maguire, Flanagan and Thornberry (1988), and MacKenzie et al. (1995)), the externalities of convict labor have never been thoroughly studied.

In this paper, I show that coercive institutions that appeared in the United States after the Civil War affected the economic welfare of free laborers. I document that convict labor decreased wages in manufacturing, especially for women. At the same time, it hastened technology adoption and capital investments that allowed firms competing with prisons to thrive.

Though troubling, the private use of convict labor was allowed again in 1979 . Convict labor benefits specific interest groups and institutions in the federal and state prison systems, as well as private prison companies. Federal Prison Industries, a U.S. government corporation operating under the federal Bureau of Prisons (BOP) (with a prison population of approximately 192,000) pays inmates roughly $\$ 0.90$ an hour to produce a wide range of everyday products, from mattresses and spectacles to road signs and body armor, for other government agencies, earning $\$ 500$ million in sales in fiscal $2016 .^{62}$ Meanwhile, state prison systems and private prisons often contract out prison labor to private manufacturing (e.g., inmates in North Carolina made lingerie for Victoria's Secret in the 1990s, and until 2016, prisoners in Colorado made goat cheese and raised tilapia for Whole Foods). ${ }^{63}$ The current expansion of private prisons is heavily debated in the pub-

\footnotetext{
${ }^{61} \mathrm{~A}$ more detailed description of Caselli and Coleman's (2006) model and its implementation in my setting appears in Appendix D. Figure D1 provides results for other industries.

62 The Economist (2017); BOP (2017).

${ }^{63}$ The Washington Post (2015); NPR (2015).
} 
lic space. ${ }^{64}$ The morning after Donald Trump was elected president, the share price of private-prison operator CoreCivic (Corrections Corporation of America) jumped 34\%, while GEO Group stocks rose by $18 \% .{ }^{65}$ Even though the BOP had been planning to stop renewing contracts with private prisons, the Trump administration has extended contracts with several private-prison companies. ${ }^{66}$

The number of convicts has soared from approximately 160,000 in 1932 to more than 2.3 million today, and the effect of contemporary convict labor on the U.S. economy is likely large. No detailed data are released on the amount and industrial composition of convict labor, but according to the U.S. Census of State and Federal Adult Correctional Facilities, approximately 1.4 million prisoners were employed in 2,500 U.S. prisons in 2005. ${ }^{67}$ From 2000 to 2005, the number of prisoners employed in manufacturing almost doubled, from approximately 308,000 to approximately 594,000. ${ }^{68}$ Today, those prisoners still receive lower-than-minimum wage and impose externalities on free labor.

However, the effects of contemporary convict labor are different from the historical effects because transportation costs have decreased over time and competition with prison-made goods may spread farther from the prison. ${ }^{69}$ Thus, the overall effect of convict labor on contemporary manufacturing wages could be smaller around the prison but larger overall. ${ }^{70}$

While I observe neither the industry where prisoners are employed nor the value of goods produced, I attempt to elicit the magnitude of the effect of competition with prison-made goods on wages in manufacturing by using a back-of-theenvelope calculation. To do it, I choose the estimate from the most appropriate specification for the contemporaneous cases - with a Bartik measure of exposure to convict labor (without trade cost) and number of employed prisoners (instead of value of goods produced). ${ }^{71}$ I assume that the relationship between convict labor and wages remains the same. Thus, this $92 \%$ increase in the number of employed prisoners led to a $\left[-0.2 \times \ln \left(\frac{594,000}{308,000}\right) \times \frac{1}{2} \approx\right] 0.07$-percentage-point decrease in

\footnotetext{
${ }^{64}$ The trend also exists in other countries. In Russia the government began allowing state-owned companies to house and employ prisoners for almost zero wages in 2017 (The Moscow Times (2016)).

${ }^{65}$ See Quartz (2016).

${ }^{66}$ See U.S. Department of Justice (2016) and CNN (2017).

${ }^{67}$ See Figure G1 for a map of contemporary prisons. Some of their prisoners are assigned to halfway houses and are allowed to work outside the prison premises.

${ }^{68}$ Source: U.S. Census of State and Federal Adult Correctional Facilities (1990, 2000, 2005).

${ }^{69}$ In addition, labor mobility has increased over time, shrinking the effects of prison proximity. However, Autor, Dorn and Hanson (2013) argue that U.S. low-skilled labor mobility remains low.

${ }^{70}$ Contemporaneous prisons are located in economically disadvantaged areas (Mattera and Khan (2001)) under the assumption that they will provide jobs. The most thorough study on this account, by Chirakijja (2018), finds positive effect of opening a prison on local labor outcomes. However, convict labor may worsen nationwide labor market-outcomes, thus overshadowing any possible positive effects from new prisons' construction. By providing evidence of adverse externalities that prison labor imposes on free labor, I address the discussion of mandatory work programs in contemporary prisons (Zatz (2008, 2009) and Polinsky (2017)).

${ }^{71}$ I also use estimates from a non-normalized explanatory variable. Estimating the effect of convict labor on changes in manufacturing employment yields a point-estimate of -0.2 (se $=0.118$ ): a $10 \%$ increase in exposure to convict labor decreases manufacturing employment by 2 percentage points in 20 years, or 1 percentage point in 10 years.
} 
manufacturing employment in 2000s, and an 0.02-percentage-point decrease in 1990s. Even if my estimate is an upper bound of the effect and the actual effect is smaller, the contemporary policy of placing prisons in economically depressed regions may be fallacious. While the 1870-1886 convict-labor shock was similar in magnitude to the China shock in 2000 and 2007, the effect of contemporaneous convict labor is relatively small, constituting $6.4 \%$ of its effect in the $2000 \mathrm{~s}$ and $3.1 \%$ in the $1990 \mathrm{~s}^{72}$ Hence, exposure to prison labor competition explains $3.5 \%$ of the manufacturing employment decline between 1990 and 2000, and $5 \%$ of the decline between 2000 and 2007, compared to $33 \%$ and $55 \%$ explained by the China shock. Finally, the fact that the number of employed prisoners between 2000 and 2005 increased by $92 \%$ while the prison population increased only by $12 \%$ suggests that some firms may be trying to use cheap U.S. prison labor to compete with Chinese imports. ${ }^{73}$

Decreased costs of international trade and trade liberalization have made import competition a more important determinant of the decline in manufacturing employment; however, prison labor (while not comparable with, e.g., the Chinese labor force) still affects labor markets. Moreover, the United States has accused China of using convict labor to produce export goods (Hairong and Sautman (2012)), while its own convict labor takes jobs from U.S. free laborers. ${ }^{74}$ I assert that the government should at least consider imposing redistributive welfare to low-skilled (local) workers to alleviate the effect of competition with convict labor.

My analysis highlights the fact that many aspects of economic life and many groups of people can be affected directly and indirectly by competition from prison-made goods. Thus, when we evaluate the overall effect of the penitentiary system, we should carefully assess the negative externalities created by convict labor.

\section{REFERENCES}

Acemoğlu, Daron. 2002. "Directed technical change." The Review of Economic Studies, 69(4): 781809.

Acemoğlu, Daron. 2007. "Equilibrium bias of technology." Econometrica, 75(5): 1371-1409.

Acemoğlu, Daron, and Alexander Wolitzky. 2011. "The economics of labor coercion." Econometrica, 79(2): 555-600.

Acemoğlu, Daron, and Amy Finkelstein. 2008. "Input and technology choices in regulated industries: Evidence from the health care sector." Journal of Political Economy, 116(5): 837-880.

Acemoğlu, Daron, and David Autor. 2011. "Skills, tasks and technologies: Implications for employment and earnings." Handbook of labor economics, 4: 1043-1171.

Acemoğlu, Daron, and Pascual Restrepo. 2017. "Robots and Jobs: Evidence from US Labor Markets." National Bureau of Economic Research.

Acemoğlu, Daron, Camilo García-Jimeno, and James A Robinson. 2012. "Finding Eldorado: Slavery and long-run development in Colombia." Journal of Comparative Economics, 40(4): 534-564.

Aghion, Philippe, Antoine Dechezleprêtre, David Hemous, Ralf Martin, and John Van Reenen. 2016. "Carbon taxes, path dependency, and directed technical change: Evidence from the auto industry." Journal of Political Economy, 124(1): 1-51.

${ }^{72}$ Here, I use estimates from Section III.B. of Autor, Dorn and Hanson (2013).

${ }^{73}$ Source: U.S. Department of Justice (2000) and U.S. Department of Justice (2000).

${ }^{74}$ E.g., The New York Times (2012). 
Angrist, Joshua D, and Jörn-Steffen Pischke. 2008. Mostly harmless econometrics: An empiricist's companion. Princeton university press.

Atack, Jeremy, and Fred Bateman. 1999. "Nineteenth-Century US Industrial Development through the Eyes of the Census of Manufactures a New Resource for Historical Research." Historical Methods: A Journal of Quantitative and Interdisciplinary History, 32(4): 177-188.

Autor, David H, David Dorn, and Gordon H Hanson. 2013. "The China syndrome: Local labor market effects of import competition in the United States." The American Economic Review, 103(6): 2121-2168.

Autor, David H, David Dorn, and Gordon H Hanson. 2016. "The China Shock: Learning from Labor-Market Adjustment to Large Changes in Trade." Annual Review of Economics, 8: 205-240.

Autor, David H, David Dorn, Gordon H Hanson, Gary Pisano, and Pian Shu. 2016. "Foreign competition and domestic innovation: Evidence from US patents." NBER.

Blanchard, Olivier Jean, and Lawrence F Katz. 1992. "Regional Evolutions." Brookings Papers on Economic Activity, 1992(1): 1-75.

Bloom, Nicholas, Mirko Draca, and John Van Reenen. 2016. "Trade induced technical change? The impact of Chinese imports on innovation, IT and productivity." The Review of Economic Studies, 83(1): 87-117.

Borjas, George J. 2003. "The labor demand curve is downward sloping: Reexamining the impact of immigration on the labor market." The quarterly journal of economics, 118(4): 1335-1374.

Borjas, George J. 2017. "The wage impact of the Marielitos: A reappraisal." ILR Review, 70(5): 10771110.

Buggle, Johannes C, and Steven Nafziger. 2018. "The Slow Road from Serfdom: Labor Coercion and Long-Run Development in the Former Russian Empire." Unpublished manuscript.

Cameron, A Colin, Jonah B Gelbach, and Douglas L Miller. 2008. "Bootstrap-based improvements for inference with clustered errors." The Review of Economics and Statistics, 90(3): 414-427.

Cameron, A Colin, Jonah B Gelbach, and Douglas L Miller. 2011. "Robust inference with multiway clustering." Journal of Business 83 Economic Statistics, 29(2): 238-249.

Card, David. 1990. "The impact of the Mariel boatlift on the Miami labor market." ILR Review, 43(2): 245-257.

Card, David. 2001. "Immigrant inflows, native outflows, and the local labor market impacts of higher immigration." Journal of Labor Economics, 19(1): 22-64.

Caselli, Francesco, and Wilbur John II Coleman. 2006. "The world technology frontier." American Economic Review, 96(3): 499-522.

Chernozhukov, Victor, Denis Chetverikov, Mert Demirer, Esther Duflo, Christian Hansen, Whitney Newey, and James Robins. 2016. "Double machine learning for treatment and causal parameters." arXiv preprint arXiv:1608.00060.

Chirakijja, Janjala. 2018. "The Local Economic Impacts of Prisons."

Clemens, Michael A, Ethan G Lewis, and Hannah M Postel. 2018. "Immigration restrictions as active labor market policy: Evidence from the mexican bracero exclusion." American Economic Review, 108(6): 1468-87.

Conley, Timothy G. 1999. "GMM estimation with cross sectional dependence." Journal of econometrics, 92(1): 1-45.

Conley, Timothy G. 2010. "Spatial econometrics." In Microeconometrics. 303-313. Springer.

Dell, Melissa. 2010. "The persistent effects of Peru's mining mita." Econometrica, 78(6): 1863-1903.

Department of Labor. 1887. Second Annual Report of the Commissioner of Labor: Convict Labor. Washington: Government Printing Office.

Department of Labor. 1896. "Convict Labor." Bulletin of the Department of Labor, 5: 470-505.

Department of Labor. 1900. Report of the Industrial Commission on Prison Labor. Prepared in conformity with act of Congress approved June 18, 1898. Volume III, Washington: United States Government Printing Office.

Department of Labor. 1906. Tventieth Annual Report of the Commissioner of Labor: Convict Labor. Washington: Government Printing Office.

Department of Labor. 1914. "Federal and State Laws Relating to Convict Labor." 63d Congress, 2nd Session, 494.

Department of Labor. 1925. Convict Labor in 1923. Washington: Government Printing Office.

Department of Labor. 1933. Prison Labor in the United States 1932. Washington: United States Government Printing Office.

Department of Labor. 1941. Prison Labor in the United States 1940. Washington: United States Government Printing Office.

Donaldson, Dave, and Richard Hornbeck. 2016. "Railroads and American Economic Growth: A "Market Access" Approach." The Quarterly Journal of Economics, 799-858. 
Dube, Arindrajit, T William Lester, and Michael Reich. 2016. "Minimum wage shocks, employment flows, and labor market frictions." Journal of Labor Economics, 34(3): 663-704.

Fishback, Price V. 1998. "Operations of" Unfettered" Labor Markets: Exit and Voice in American Labor Markets at the Turn of the Century." Journal of Economic Literature, 36(2): 722-765.

Fishback, Price V, Michael R Haines, and Shawn Kantor. 2007. "Births, deaths, and New Deal relief during the Great Depression." The review of economics and statistics, 89(1): 1-14.

Fogel, Robert William. 1964. Railroads and American economic growth: essays in econometric history. Vol. 296, Johns Hopkins Press Baltimore.

Gildemeister, Glen A. 1978. "Prison labor and convict competition with free workers in industrializing America, 1840-1890."

Goldin, Claudia. 2000. "Labor markets in the twentieth century."

Goldin, Claudia, and Lawrence F Katz. 1998. "The origins of technology-skill complementarity." The Quarterly journal of economics, 113(3): 693-732.

Goldin, Claudia, and Lawrence F Katz. 2012. "The race between education and technology: The evolution of US educational wage differentials, 1890 to 2005." National Bureau of Economic Research.

Grosjean, Pauline. 2014. "A history of violence: The culture of honor and homicide in the US south." Journal of the European Economic Association, 12(5): 1285-1316.

Haines, Michael R. 2004. "The Inter-university Consortium for Political and Social Research. Historical, Demographic, Economic, and Social Data: The United States, 1790-2000 [Computer file]. ICPSR02896-v2. Hamilton, NY: Colgate University." Ann Arbor: MI: Inter-university Consortium for Political and Social Research [producers].

Hairong, Yan, and Barry Sautman. 2012. "Chasing ghosts: rumours and representations of the export of Chinese convict labour to developing countries." The China Quarterly, 210: 398-418.

Hanlon, W Walker. 2015. "Necessity is the mother of invention: Input supplies and Directed Technical Change." Econometrica, 83(1): 67-100.

Hansen, Christian B. 2007. "Asymptotic properties of a robust variance matrix estimator for panel data when T is large." Journal of Econometrics, 141(2): 597-620.

Hiller, Ernest T. 1915. "Labor unionism and convict labor." Journal of the American Institute of Criminal Law and Criminology, 5(6): 851-879.

Holmes, Thomas J, and John J Stevens. 2014. "An alternative theory of the plant size distribution, with geography and intra-and international trade." Journal of Political Economy, 122(2): 369-421.

Hornbeck, Richard. 2010. "Barbed wire: Property rights and agricultural development." The Quarterly Journal of Economics, 125(2): 767-810.

Hornbeck, Richard, and Martin Rotemberg. 2018. "Engines of Productivity Growth: Railroads, Reallocation, and the Rise of American Manufacturing."

Hornbeck, Richard, and Suresh Naidu. 2014. "When the levee breaks: black migration and economic development in the American South." American Economic Review, 104(3): 963-90.

IL BLS. 1886. Biennial Report. Illinois, Bureau of Labor Statisticsy.

Illinois State Penitentiary. 1857. Annual Report of the Inspectors of the Penitentiary. Illinois, Reports to the General Assembly.

Katz, Lawrence F, and Robert A Margo. 2014. "Technical change and the relative demand for skilled labor: The united states in historical perspective." In Human capital in history: The American record. 15-57. University of Chicago Press.

Kline, Patrick, and Enrico Moretti. 2014. "Local Economic Development, Agglomeration Economies, and the Big Push: 100 Years of Evidence from the Tennessee Valley Authority." The Quarterly Journal of Economics, 129(1): 275-331.

Kovak, Brian K. 2013. "Regional effects of trade reform: What is the correct measure of liberalization?" American Economic Review, 103(5): 1960-76.

Lewis, Ethan. 2011. "Immigration, skill mix, and capital skill complementarity." The Quarterly Journal of Economics, 126(2): 1029-1069.

Lewis, Orlando F. 1922. The development of American prisons and prison customs, 1776-1845: With special reference to early institutions in the state of New York. Prison Association of New York.

Lowes, Sara, and Eduardo Montero. 2017. "Blood Rubber: The Effects of Labor Coercion on Institutions and Culture in the DRC." Working paper, Harvard.

Lynch, James P, and William J Sabol. 2000. "Prison use and social control." Criminal justice, 3: 7-44.

MacKenzie, Doris Layton, Robert Brame, David McDowall, and Claire Souryal. 1995. "Boot camp prisons and recidivism in eight states." Criminology, 33(3): 327-358.

Maguire, Kathleen E, Timothy J Flanagan, and Terence P Thornberry. 1988. "Prison labor and recidivism." Journal of Quantitative Criminology, 4(1): 3-18.

Markevich, Andrei, and Ekaterina Zhuravskaya. 2018. "The Economic Effects of the Abolition of Serfdom: Evidence from the Russian Empire." American Economic Review, 108(4-5): 1074-1117. 
Mattera, P, and M Khan. 2001. "Jail breaks: Economic development subsidies given to private prisons. Washington, DC: Good Jobs First."

McKelvey, Blake. 1934. "The Prison Labor Problem: 1875-1900." Journal of Criminal Law and Criminology (1931-1951), 25(2): 254-270.

McKelvey, Blake. 1936. American prisons: A study in American social history prior to 1915. University of Chicago Press.

Meyer, Peter B. 2004. The Weeks Report database, 4th edition. Available online: http://econterms.net/weeksreport/weeksdoc.htm.

Naidu, Suresh. 2010. "Recruitment restrictions and labor markets: Evidence from the postbellum U.S. South." Journal of Labor Economics, 28(2): 413-445.

Naidu, Suresh, and Noam Yuchtman. 2013. "Coercive Contract Enforcement: Law and the Labor Market in Nineteenth Century Industrial Britain." American Economic Review, 103(1): 107-44.

Naidu, Suresh, and Noam Yuchtman. 2016. "Labor Market Institutions in the Gilded Age of American Economic History." National Bureau of Economic Research.

Newell, Richard G, Adam B Jaffe, and Robert N Stavins. 1999. "The induced innovation hypothesis and energy-saving technological change." The Quarterly Journal of Economics, 114(3): 941-975.

Nilsson, Eric A. 1994. "Empirical evidence that the social relations of production matter: the case of the ante-bellum US South." Cambridge Journal of Economics, 18(3): 259-277.

North American Review. 1866. American Prisons. VOL. CIII, Cambridge.

Nunn, Nathan. 2008. "The long-term effects of Africa's slave trades." The Quarterly Journal of Economics, 123(1): 139-176.

Nunn, Nathan, and Leonard Wantchekon. 2011. "The Slave Trade and the Origins of Mistrust in Africa." The American Economic Review, 101: 3221-3252.

Ottaviano, Gianmarco IP, and Giovanni Peri. 2012. "Rethinking the effect of immigration on wages." Journal of the European economic association, 10(1): 152-197.

Petralia, Sergio, Pierre-Alexandre Balland, and David L Rigby. 2016. "Unveiling the geography of historical patents in the United States from 1836 to 1975." Scientific data, 3: 160074.

Polinsky, A Mitchell. 2017. "Prison Work Programs in a Model of Deterrence." American Law and Economics Review, 19(2): 391-422.

Popp, David. 2002. "Induced innovation and energy prices." The American Economic Review, 92(1): 160-180.

Redding, Stephen, and Anthony J Venables. 2004. "Economic geography and international inequality." Journal of international Economics, 62(1): 53-82.

Research Foundation, Laogai. 2006. "Laogai Handbook: 2005-2006."

Rhode, Paul W., and Koleman S. Strumpf. 2003. "Assessing the importance of Tiebout sorting: Local heterogeneity from 1850 to 1990." The American Economic Review, 93(5): 1648-1677.

Ruggles, Steven, Katie Genadek, Ronald Goeken, Josiah Grover, and Matthew Sobek. 2015. "Integrated Public Use Microdata Series: Version 6.0." Minneapolis: University of Minnesota.

Sellin, Johan Thorsten. 1976. "Slavery and the penal system."

Sharkey, Charles F., and George D. Patterson. 1933. Laws Related to Prison Labor in the United States as of July 1, 1933. Washington: United States Government Printing Office.

Shichor, David. 1995. Punishment for profit. Sage Publications.

Thies, Clifford F. 1990. "The first minimum wage laws." Cato J., 10: 715.

Topalova, Petia. 2010. "Factor immobility and regional impacts of trade liberalization: Evidence on poverty from India." American Economic Journal: Applied Economics, 2(4): 1-41.

van der Linden, Marcel, and M Rodríguez García. 2016. "On Coerced Labor: Work and Compulsion after Chattel Slavery." Studies in Global Social History.

Weiss, Harry Bischoff, and Grace M Weiss. 1961. The Early Hatters of New Jersey. New Jersey Agricultural Society.

Wilson, Walter. 1933. Forced labor in the United States. International Publishers New York.

Wines, E.C. 1871. Transactions of the National Congress of Penitentiary and Reformatory Discipline held at Cincinati, Ohio, October 12-18, 1870. Albany: The Argus company, printers.

Wisconsin, Legislature. 1850. Report of the Committee on State Affairs in relation to State Prison. Legis. Doc. 50.

Wooldridge, Jeffrey M. 2015. Introductory econometrics: A modern approach. Nelson Education.

Xu, Meng. 2018. "Regional Competition and Economic Growth: Winners and Losers from Market Integration."

Zatz, Noah D. 2008. "Working at the boundaries of markets: Prison labor and the economic dimension of employment relationships." Vand. L. Rev., 61: 857.

Zatz, Noah D. 2009. "Prison labor and the paradox of paid nonmarket work." In Economic Sociology of Work. 369-398. Emerald Group Publishing Limited.

Zhang, Linyi. 2018. "Escaping Chinese Import Competition? Evidence from U.S. Firm Innovation." 
Online Appendix

to

"Economic Consequences of the U.S.

Convict Labor System" 


\section{AdDITIONAL BACKGROUND INFORMATION}

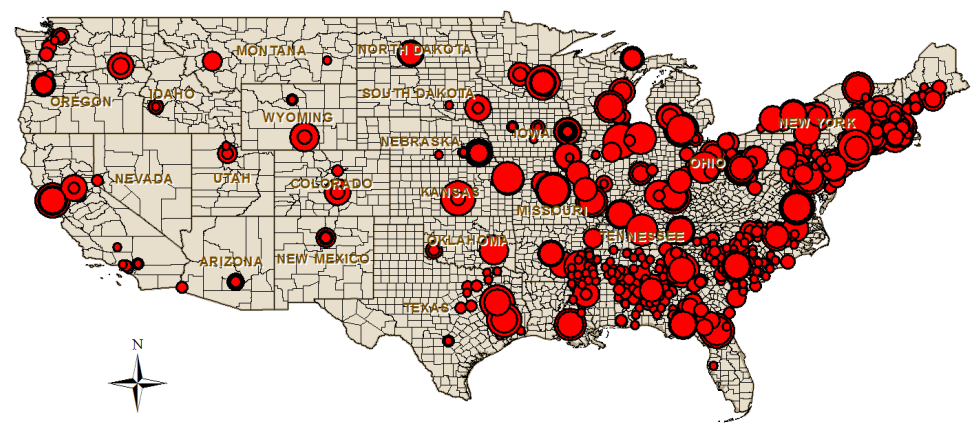

Figure A1. Prisons and Convict-labor Camps from the novel Dataset (1886-1940)

Note: Computed using data from the Department of Labor (1887, 1896, 1906, 1914, 1925, 1933, 1941). Each dot is a prison. The red dots represent the total value of goods produced in prisons.

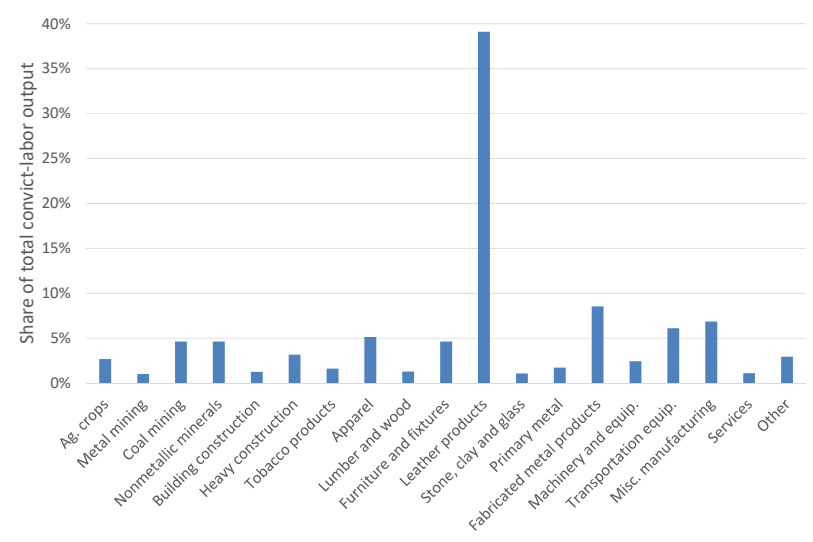

Figure A2. Convict Labor By two-digit SIC Code (1886)

Note: Computed using data from the Department of Labor (1887). 
Panel A

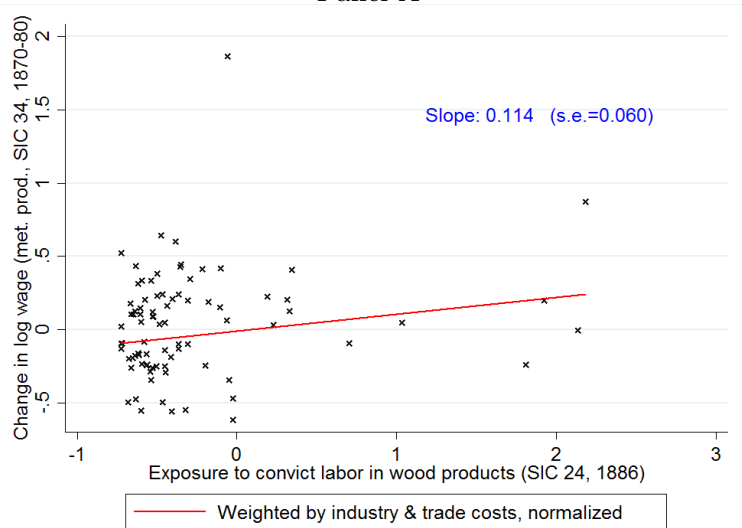

Panel B

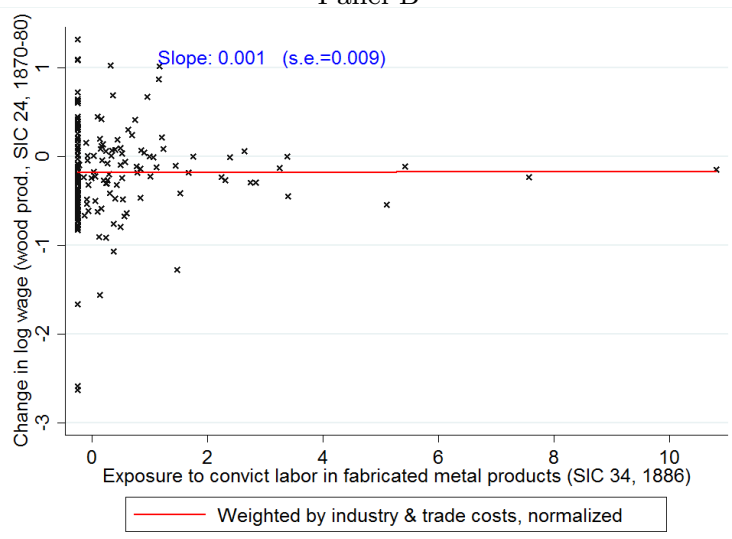

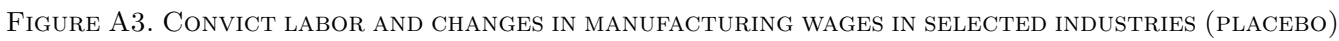

Note: In Panel A(B), each cross is a county that had firms in the fabricated metal products (lumber and wood products (except furniture)) industry. In Panel B(A), exposure to prison-made goods is computed as a Bartik measure weighted by industry labor share and trade costs but uses only goods produced in the fabricated metal products (lumber and wood products (except furniture)) industry. I use changes in wages from 1870 to 1880 , as the county-industry data are not available starting from 1890 . 
Panel A

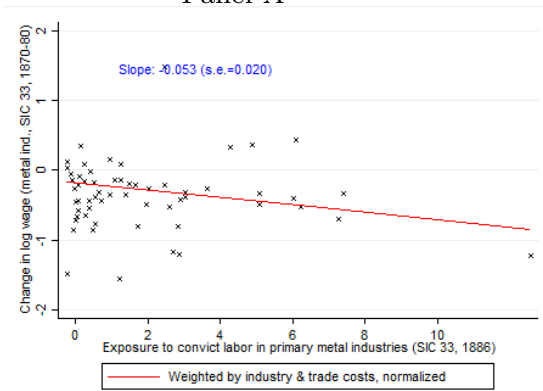

Panel C

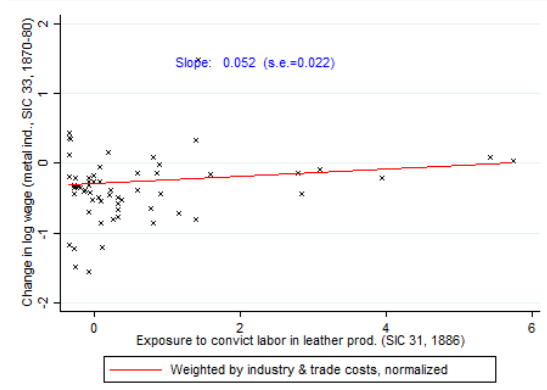

Panel B

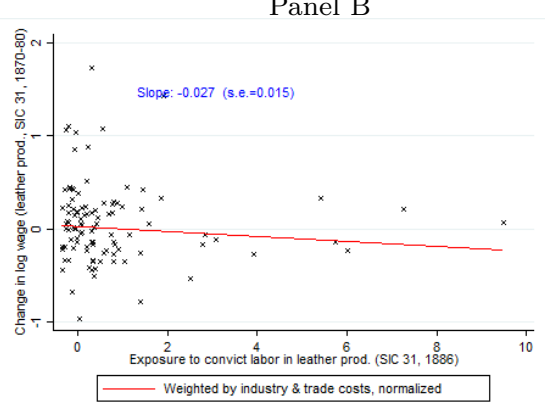

Panel D

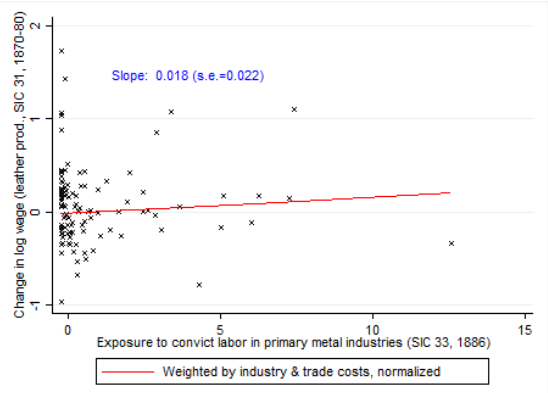

Figure A4. Convict Labor and Changes in manufacturing Wages in the Leather goods AND PRIMARY METAL INDUSTRIES

Note: In Panels A and C (B and D), each cross is a county that had firms in the primary metal products (leather products) industry. In Panels A and D (B and C), exposure to prison-made goods is computed as a Bartik measure weighted by industry labor share and trade costs but that uses only goods produced in the primary metal products (leather products) industry. I use changes in wages from 1870 to 1880 , as the county-industry data are not available starting from 1890. 
Panel A

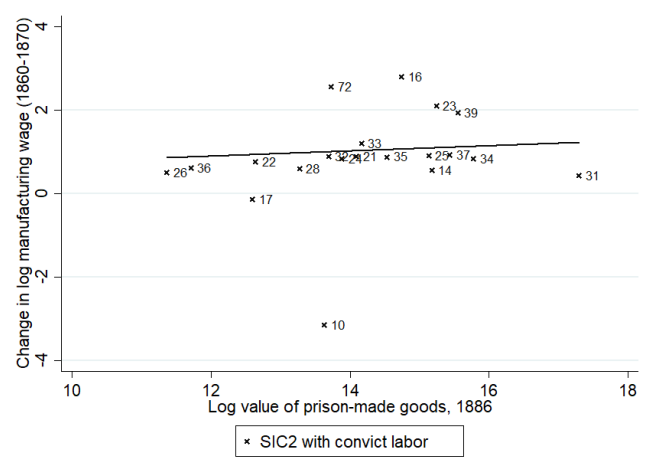

Panel B

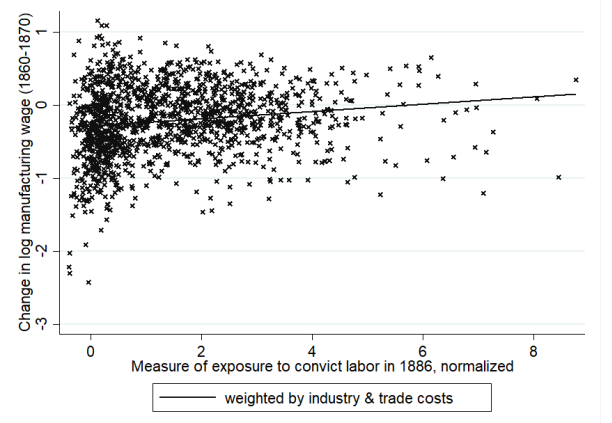

Figure A5. Convict Labor And Changes in manufacturing Wages

Note: In Panel A, each cross is a two-digit SIC code. In Panel A, exposure to prison-made goods computed as total value of prison-made goods produced in that industry. In Panel $\mathrm{B}$, each cross is a county. In Panel B, exposure to prison-made goods computed as Bartik measure weighted by industry labor share and trade costs. Counties that did not experience convict labor shock because they do not have industries in which convicts were employed are excluded for the sake of better data representation. 


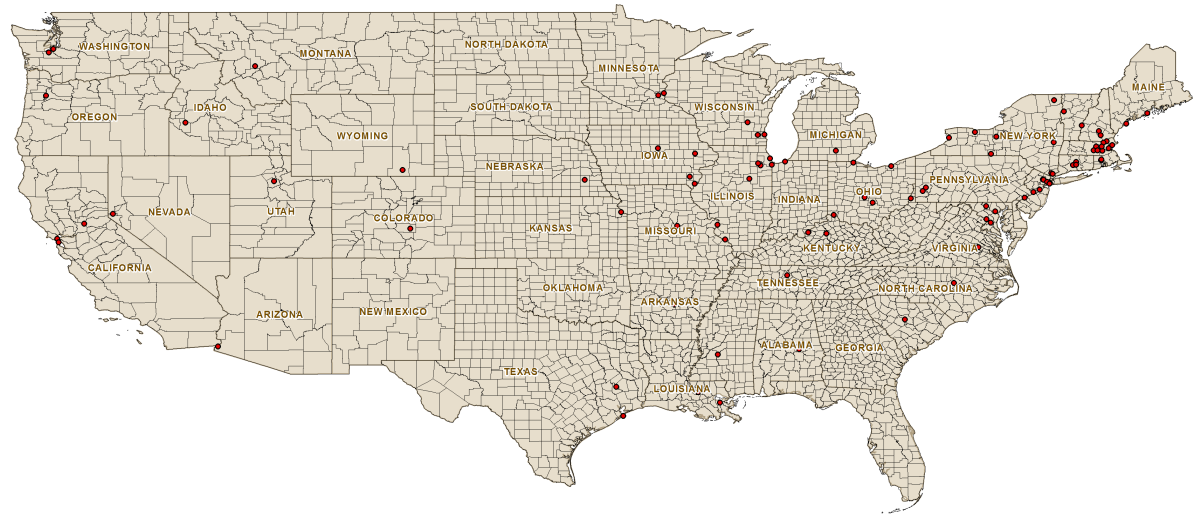

Figure A6. Prisons in 1870

Note: Red dots represent locations of state prisons and penitentiaries that existed before their states adopted convict-labor legislation. Source: Locations are from North American Review (1866) and Wines (1871), and coordinates are found using R. 


\section{Data Appendix}

All individual and county-level data for controls are taken from U.S. censi (Haines (2004); Ruggles et al. (2015)). All legislation related to convict labor is available in Department of Labor $(1887,1941)$ and Sharkey and Patterson (1933). GPS coordinates of some prisons are difficult to determine, since most of them no longer exist; instead, I use coordinates of the town where it was located. In the few cases where several prisons are located in the same town, I aggregate to the GPS coordinates of the town. I follow the approach developed in Hornbeck (2010) to deal with changes in counties' borders when I construct a panel dataset.

I work with county level data for the years 1850 to 1950. The data for the years 1850 to 1950 were obtained from Historical, Demographic, Economic, and Social Data: The United States, 1790-2000, ICPSR 2896 (Haines (2004)). Some variables are built from individual-level data from IPUMS from a 1\% extract from the 1850, 1860, 1870, 1880, 1900, 1910, 1920, 1930, 1940, and 1950 censi, respectively (Ruggles et al. (2015)). In addition, I use data on county topography and demographics from "Data Set for Births, Deaths, and New Deal Relief During the Great Depression," a paper by Fishback, Haines and Kantor (2007) generously made available on Price Fishback's website.

I drop underpopulated counties with a population of less than 1,000 in any decade in my sample for the panel specification, and drop counties with a population of less than 1,000 in 1890 for the cross-sectional specification in first differences.

The quality of some of the key variables is not ideal. Substantial measurement error is likely to be present. Specifically, the key dependent variables are as follows:

- Average annual wage in manufacturing. Direct data on workers' wages are unavailable at the county level. As an expedient, I proxy for the average wage in manufacturing by dividing the total annual wage bill in manufacturing by the estimated number of workers in the industry. Wages by gender are computed using the number of employed workers by gender. Source: ICPSR 2896 for county-level data; Atack and Bateman (1999) for firm-level data; Hornbeck and Rotemberg (2018) for 1860, and 1880 county-industrylevel data; from Table XI of the "Compendium of the Ninth Census" for the 1870 county-industry-level data. ${ }^{75}$ Wages (by gender) for 1940 and 1950 are computed as aggregated county-level wages of manufacturing workers. Source: IPUMS.

- Employment share in manufacturing. Share of people employed in manufacturing out of total number of employed people. Source: IPUMS.

\footnotetext{
${ }^{75}$ This is unlikely to provide a perfect measure of the marginal product of labor, as it fails to account for differences in the number of hours worked and the quality of workers. Moreover, in some counties, the wage bill is missing. For agriculture, the county wage bill is not available, so there is no good way to compute an average agricultural wage.
} 
- Labor-force participation rate. Share of employed people out of total number of people in the labor force. Source: IPUMS.

- Number of patents in affected industries. Number of patents in industries where prisoners were employed (agriculture, food, textiles; agriculture, husbandry, food; furniture, house fixtures; apparel and textile; coating; earth working and wells; electrical lighting; gas; heating; material processing and handling; metal working; miscellaneous (electric, mechanical, chemical, others); pipes and joints; receptacles; transportation). Source: Petralia, Balland and Rigby (2016).

- Number of patents in nonaffected industries. Number of patents in industries where prisoners were not employed (communications; computer hardware and software; computer peripherals; drugs; electrical devices; information storage; measuring and testing; miscellaneous drugs and medicine; motors, engines, and parts; nuclear and X-rays; optics; organic compounds; power systems; resins; semiconductor devices; surgery and medical instrument) Source: Petralia, Balland and Rigby (2016).

- Capital-labor ratio. I divide the total capital by the number of employed workers in the industry $\left(\frac{K}{L}\right)$. Source: ICPSR 2896 for county-level data; Atack and Bateman (1999) for firm-level data.

- Returns-to-capital to returns-to-labor ratio. I divide returns-to-capital $(r)$ by returns-to-labor (wage $w)\left(\frac{r}{w}\right)$. As I don't observe $r$, I compute it from the manufacturing outcome $(Y)$, wage share $(w L)$, and capital $(K): r=$ $\frac{Y-w L}{K}$. Source: ICPSR 2896.

Here, I provide the list of control variables:

- Total population of each county. Source: ICPSR 2896.

- Urban population in each county divided by the total population of each county. For 1850 to 1920, it was calculated as population residing in places of 2,500 or more persons. For 1930, 1940, and 1950, calculated directly as the total urban population. Source: ICPSR 2896.

- Share of population of African-Americans. Defined as the share of Black people over the total population. Source: ICPSR 2896.

- Share of foreign-born population. Defined as the share of foreign-born population over the total population. Source: ICPSR 2896.

- Share of women. Defined as the share of women over the total population. Source: ICPSR 2896.

- Manufacturing total employment. For 1850 to 1940, it was defined as the average number of manufacturing wage earners, and for 1950 it was defined as manufacturing production workers. Source: ICPSR 2896. 
- Value of manufacturing output. Source: ICPSR 2896.

- Share of migrants. Defined as the share of migrants at 1940 computed out of the total population using question: "State or country of residence 5 years ago." Source: IPUMS.

- Value of farm products. For 1900, it was defined as the value of miscellaneous crops with acreage reported in 1899 plus the value of miscellaneous crops without acreage reported in 1899. For 1910 to 1930, it was defined as the value of all crops. For 1940, it was defined as the value of all farm products sold, traded, or used. For 1950, it was defined as the value of all farm products sold. Data are missing for 1850 and 1860. Source: ICPSR 2896.

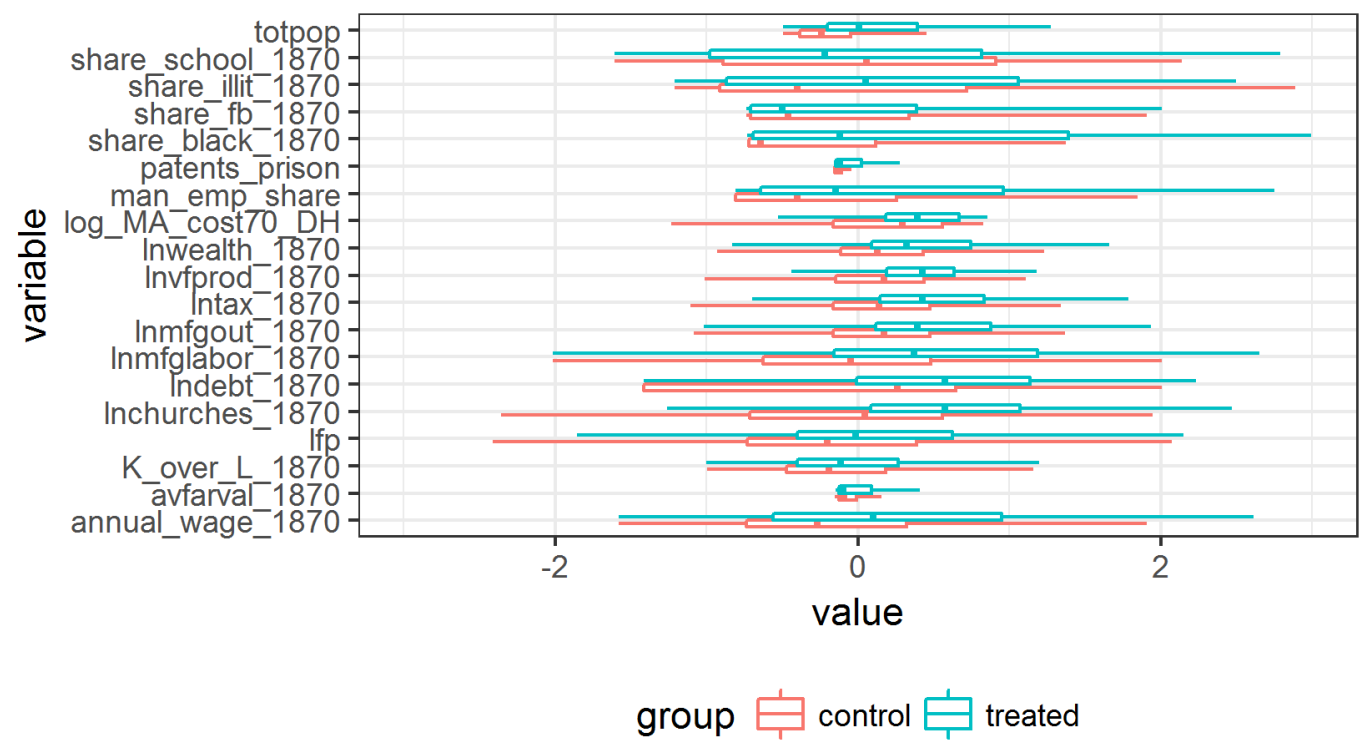

Figure B1. Balance table

Note: Data are for 1870. $99 \%$ and $95 \%$ confidence intervals are depicted. The red color represents counties with prisons that employed prisoners in 1886. The blue color represents counties that did not have prisons that employed prisoners in 1886.

While counties with prisons are not statistically different in terms of covariates from the counties without prisons (see Table B1), as a robustness check, I choose to trim the sample by omitting "worst possible" control counties (e.g., as in Kline and Moretti (2014)). To do so, I employ propensity score matching on covariates for the pretreatment year of 1870 . As there could be other important unobservables not mentioned by the historians, it could render the propensity score 
estimation incorrect if I do not include them. Thus following an idea mentioned in Chernozhukov et al. (2016), I use all possible covariates from the cross-section of 1870 county-level data and run LASSO. Then I use the most important covariates to estimate the propensity score. Finally, I drop all counties whose propensity score is below an arbitrary threshold (15\%).

The trimmed sample has a slightly better balancing properties (Table B2). However, trimming the sample does not change my results. Results with the trimmed sample are available upon request.

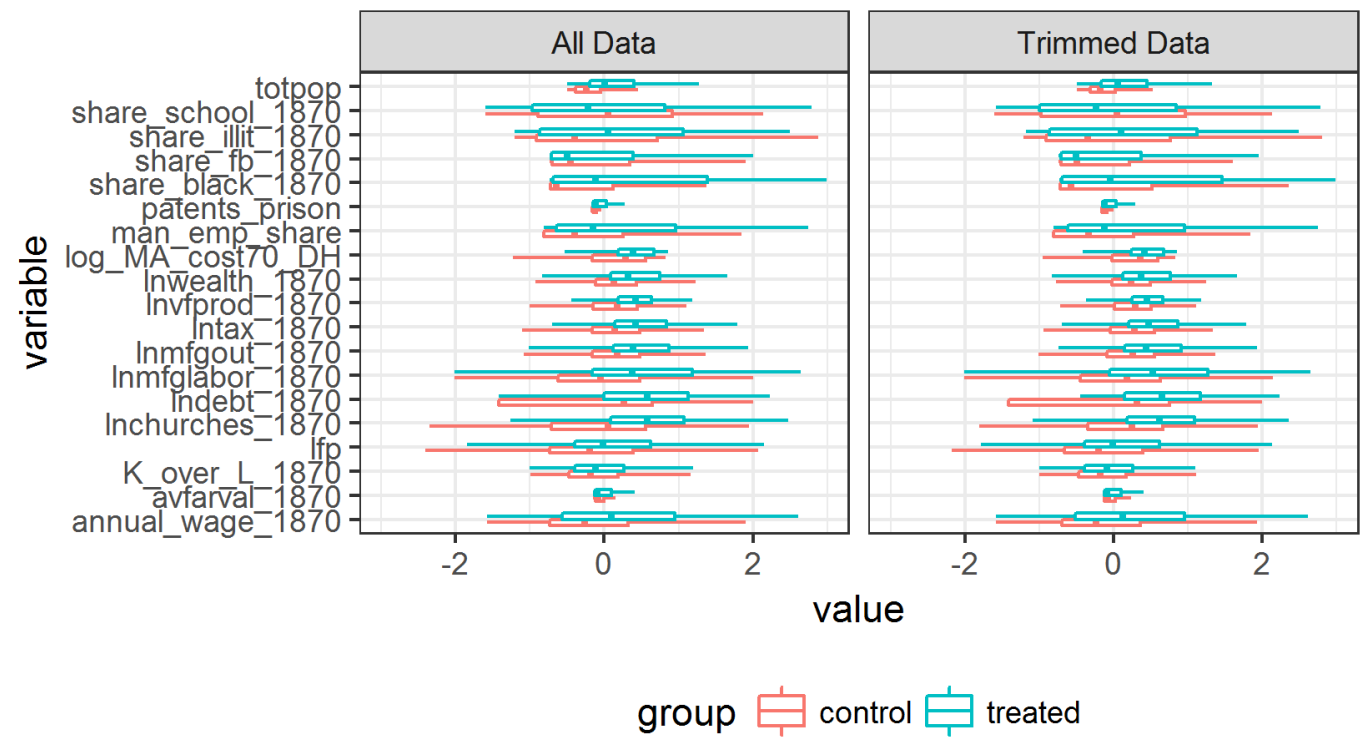

Figure B2. Balance table in full And trimmed SAmples

Note: Data are for 1870. $99 \%$ and 95\% confidence intervals are depicted. The red color represents counties with prisons that employed prisoners in 1886. The blue color represents counties that did not have prisons that employed prisoners in 1886. Trimmed data represent a sample of counties that omit a $15 \%$ of control counties with the lowest propensity score (counties least likely to have a prison that employed prisoners). 


\section{Introduction of Convict Labor: Additional Results}

\section{C1. Reduced-Form Results}

TABLE C1-REDUCED-FORM RESUlTS: LOCAL LABOR-MARKET OUTCOMES AND old PRISONS

\begin{tabular}{lccc}
\hline \hline & \multicolumn{3}{c}{ Introduction of Convict Labor (1870-1886) } \\
\cline { 2 - 4 } Outcome: & I & II & III \\
\cline { 2 - 4 } Old Prison Capacities & $\Delta$ log Wage in & $\Delta$ Labor-Force & $\Delta$ Employment Share \\
& Manufacturing & Participation & in Manufacturing \\
\cline { 2 - 4 } & $-0.005^{*}$ & $-0.004^{* *}$ & $-0.001^{* *}$ \\
& $(0.003)$ & $(0.001)$ & $(0.001)$ \\
R-squared & & & \\
Observations & 0.234 & 0.098 & 0.053 \\
\hline \hline
\end{tabular}

Note: All columns contain a constant and the following control variables (in changes, 1870--1880): $\log$ manufacturing output, log total population, urban share, share of Black population, share of foreignborn population, log value of farms, log county's area, latitude, and longitude. Robust clustered by state standard errors are in parentheses. ${ }^{* * *} \mathrm{p}<0.01,{ }^{* *} \mathrm{p}<0.05,{ }^{*} \mathrm{p}<0.1$

TABle C2-Reduced-Form Results: Firms AND old PRISONS

\begin{tabular}{lcccc}
\hline \hline & \multicolumn{3}{c}{ Introduction of Convict Labor (1870-1886) } \\
\cline { 2 - 5 } & \multicolumn{1}{c}{ II } & III & IV & $\mathrm{V}$ \\
\cline { 2 - 5 } Outcome (1880-1900): & $\begin{array}{c}\Delta \text { Patents in } \\
\text { Competing Industries }\end{array}$ & $\begin{array}{c}\Delta \text { Patents in } \\
\text { Noncompeting } \\
\text { Industries }\end{array}$ & $\Delta$ Capital-Labor Ratio & $\Delta(\mathrm{r} / \mathrm{w})$ \\
\cline { 2 - 5 } Old Prison Capacities & $3.920^{* *}$ & -0.418 & $8.819^{*}$ & $0.0036^{* *}$ \\
& $(1.585)$ & $(1.179)$ & $(4.449)$ & $(0.000)$ \\
R-squared & 0.950 & 0.911 & 0.046 & 0.215 \\
Observations & 1,602 & 1,602 & 1,608 & 1,603 \\
\hline \hline
\end{tabular}

Note: All columns contain a constant and the following control variables (in changes, 1870--1880): $\log$ manufacturing output, log total population, urban share, share of Black population, share of foreignborn population, log value of farms, log county's area, latitude, and longitude. Robust, clustered-by-state standard errors are in parentheses. ${ }^{* * *} \mathrm{p}<0.01,{ }^{* *} \mathrm{p}<0.05,{ }^{*} \mathrm{p}<0.1$ 


\section{C2. Alternative Measures of the Explanatory Variable}

\section{Number of Employed Convicts}

Here I show robustness of my results to a specification with the number of employed convicts instead of the value of prison-made goods. Table C5 contains the results, and the explanatory variables are as follows:

$$
\begin{gathered}
C L_{c, 1886}^{\text {continuous }}=\sum_{i \in I}\left(\lambda_{i, c} \times \sum_{k \in K} \frac{\ln \left(\# \text { of employed } \text { convicts }_{i, k, 1886}\right)}{\left(\text { Trade } \operatorname{costs}_{c, k}\right)}\right), \text { and } \\
C L_{c, 1886}^{\text {discrete }}=\sum_{i \in I}\left(\lambda_{i, c} \times \ln \left(\# \text { of employed } \text { convicts }_{i, c, 1886}\right)\right) .
\end{gathered}
$$

Table C3-Convict labor and local labor markets: Specifications with number of employed

\begin{tabular}{|c|c|c|c|c|c|c|}
\hline \multirow[t]{2}{*}{ 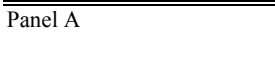 } & \multicolumn{6}{|c|}{$\begin{array}{l}\text { Introduction of Convict Labor (1870-1886) } \\
\end{array}$} \\
\hline & I & II & III & IV & $\mathrm{V}$ & VI \\
\hline \multirow[t]{2}{*}{ Outcome (1880-1900): } & \multicolumn{2}{|c|}{$\begin{array}{l}\Delta \text { log Wage in } \\
\text { Manufacturing }\end{array}$} & \multicolumn{2}{|c|}{$\begin{array}{l}\Delta \text { Labor-Force } \\
\text { Participation }\end{array}$} & \multicolumn{2}{|c|}{$\begin{array}{l}\Delta \text { Employment Share } \\
\text { in Manufacturing }\end{array}$} \\
\hline & OLS & 2SLS & OLS & $2 \mathrm{SLS}$ & OLS & $2 \mathrm{SLS}$ \\
\hline Convict Labor (continuous) & $\begin{array}{c}-0.015^{* *} \\
(0.007)\end{array}$ & $\begin{array}{l}-0.051^{*} \\
(0.028)\end{array}$ & $\begin{array}{l}-0.002 \\
(0.003)\end{array}$ & $\begin{array}{c}-0.04 * * \\
(0.01)\end{array}$ & $\begin{array}{l}-0.002 \\
(0.003)\end{array}$ & $\begin{array}{c}-0.0148^{* *} \\
(0.00730)\end{array}$ \\
\hline First-stage instrument's coef. & & $\begin{array}{c}0.097 * * * \\
(0.023)\end{array}$ & & $\begin{array}{c}0.103 * * * \\
(0.018)\end{array}$ & & $\begin{array}{c}0.101 * * * \\
(0.024)\end{array}$ \\
\hline -squar & 0.259 & 0.25 & 0.091 & -0.02 & 0.050 & 0.03 \\
\hline F-stat & & 17.76 & & 31.69 & & 18.43 \\
\hline Observatic & 1,603 & 1,603 & 1,603 & 1,603 & 1,603 & 1,603 \\
\hline \multirow[t]{2}{*}{ Panel B } & \multicolumn{6}{|c|}{ "Introduction of Convict Labor (1870-1886) } \\
\hline & $\mathrm{I}$ & II & III & IV & $\mathrm{V}$ & VI \\
\hline \multirow[t]{2}{*}{ Outcome (1880-1900): } & \multicolumn{2}{|c|}{$\Delta$ log Wage in } & \multicolumn{2}{|c|}{$\Delta$ Labor-Force } & \multicolumn{2}{|c|}{$\Delta$ Employment Share } \\
\hline & OLS & 2SLS & OLS & 2SLS & OLS & 2 2SLS \\
\hline Convict Labor (discrete) & $\begin{array}{l}-0.000 \\
(0.000)\end{array}$ & $\begin{array}{l}-0.027^{*} \\
(0.016)\end{array}$ & $\begin{array}{l}-0.000 \\
(0.000)\end{array}$ & $\begin{array}{l}-0.02^{*} \\
(0.01)\end{array}$ & $\begin{array}{c}0.000 \\
(0.000)\end{array}$ & $\begin{array}{c}-0.00898^{* *} \\
(0.00442)\end{array}$ \\
\hline First-stage instrument's coef. & & $\begin{array}{c}0.183^{* * * *} \\
(0.066)\end{array}$ & & $\begin{array}{l}0.213^{* *} \\
(0.089)\end{array}$ & & $\begin{array}{c}0.167 * * * \\
(0.056)\end{array}$ \\
\hline R-squar & 0.257 & 0.16 & 0.090 & -0.33 & 0.049 & -0.11 \\
\hline F-stat. of excl. & & 7.69 & & 5.68 & & 8.82 \\
\hline Observations & 1,603 & 1,603 & 1,603 & 1,603 & 1,603 & 1,603 \\
\hline
\end{tabular}
CONVICTS

Note: Exposure to convict labor is normalized. All columns contain a constant. The following variables are used as controls (in changes): ln of total population, urban share, share of Black population, share of foreign-born population, ln of manufacturing output, ln of value of farm products, and log of market access (the change and the base level of 1870). All columns have corresponding lagged outcome variable (level) as a control. Robust, clustered-by-state standard errors are in parentheses. ${ }^{* * *} \mathrm{p}<0.01,{ }^{* *} \mathrm{p}<$ $0.05, * \mathrm{p}<0.1$ 


\section{Alternative Weighting $(\lambda)$}

Table C4-Convict Labor and local labor markets: Specifications with alternative weighting

\begin{tabular}{|c|c|c|c|c|c|c|c|c|c|c|c|c|}
\hline \multirow{4}{*}{ Outcome (1880-1900): } & \multicolumn{12}{|c|}{ 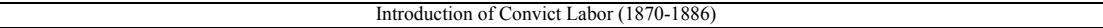 } \\
\hline & I & II & III & IV & $\mathrm{V}$ & VI & VII & VIII & IX & $\mathrm{X}$ & $\mathrm{XI}$ & XII \\
\hline & \multicolumn{12}{|c|}{$\Delta \log$ Wage in Manufacturing } \\
\hline & OLS & 2 SLS & OLS & $2 \mathrm{SLS}$ & OLS & $2 \mathrm{SLS}$ & OLS & $2 \mathrm{SLS}$ & OLS & $2 \mathrm{SLS}$ & OLS & $2 \mathrm{SLS}$ \\
\hline Weights & \multicolumn{4}{|c|}{1880 , labor share } & \multicolumn{4}{|c|}{1870 , value share } & \multicolumn{4}{|c|}{1880 , value share } \\
\hline Convict Labor (Continuous) & $\begin{array}{l}-0.006 \\
(0.004)\end{array}$ & $\begin{array}{l}-0.030^{*} \\
(0.017)\end{array}$ & & & $\begin{array}{l}-0.009 \\
(0.006)\end{array}$ & $\begin{array}{l}-0.048^{*} \\
(0.028)\end{array}$ & & & $\begin{array}{c}-0.004 \\
(0.004)\end{array}$ & $\begin{array}{l}-0.035 \\
(0.022)\end{array}$ & & \\
\hline Convict Labor (Discrete) & & & $\begin{array}{c}-0.004 \\
(0.002)\end{array}$ & $\begin{array}{l}-0.007^{*} \\
(0.004)\end{array}$ & & & $\begin{array}{l}-0.004 * \\
(0.002)\end{array}$ & $\begin{array}{l}-0.007 * \\
(0.004)\end{array}$ & & & $\begin{array}{l}-0.004 \\
(0.002)\end{array}$ & $\begin{array}{l}-0.007 * \\
(0.004)\end{array}$ \\
\hline Observations & 1,603 & 1,603 & 1,602 & 1,602 & 1,603 & 1,603 & 1,603 & 1,603 & 1,603 & 1,603 & 1,603 & 1,603 \\
\hline F-stat. of excl. inst. & & 17.33 & & 58.28 & & 8.70 & & 90.29 & & 4.98 & & 60.03 \\
\hline \multirow[t]{2}{*}{ Outcome (1880-1900): } & \multicolumn{12}{|c|}{ 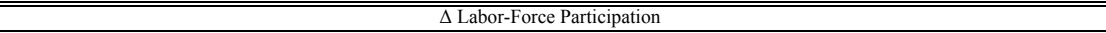 } \\
\hline & OLS & 2 SLS & OLS & 2 SLS & OLS & 2 SLS & OLS & 2SLS & OLS & $2 \mathrm{SLS}$ & OLS & $2 \mathrm{SLS}$ \\
\hline Weights & \multicolumn{4}{|c|}{1880 , labor share } & \multicolumn{4}{|c|}{1870 , value share } & \multicolumn{4}{|c|}{1880 , value share } \\
\hline Convict Labor (Continuous) & $\begin{array}{l}-0.002 \\
(0.001)\end{array}$ & $\begin{array}{c}-0.008^{* *} \\
(0.004)\end{array}$ & & & $\begin{array}{l}-0.001 \\
(0.002)\end{array}$ & $\begin{array}{l}-0.012^{*} \\
(0.006)\end{array}$ & & & $\begin{array}{l}-0.001 \\
(0.001)\end{array}$ & $\begin{array}{l}-0.010^{*} \\
(0.006)\end{array}$ & & \\
\hline Convict Labor (Discrete) & & & $\begin{array}{l}-0.001 \\
(0.001)\end{array}$ & $\begin{array}{c}-0.002 * * \\
(0.001)\end{array}$ & & & $\begin{array}{c}-0.002 * * \\
(0.001)\end{array}$ & $\begin{array}{c}-0.002 * * \\
(0.001)\end{array}$ & & & $\begin{array}{l}-0.001 \\
(0.001)\end{array}$ & $\begin{array}{c}-0.002 * * \\
(0.001)\end{array}$ \\
\hline Observations & 1,603 & 1,603 & 1,602 & 1,602 & 1,603 & 1,603 & 1,603 & 1,603 & 1,603 & 1,603 & 1,603 & 1,603 \\
\hline F-stat. of excl. inst. & & 22.81 & & 56.51 & & 11.04 & & 90.71 & & 6.01 & & 58.37 \\
\hline \multirow[t]{2}{*}{$\overline{\text { Outcome (1880-1900): }}$} & \multicolumn{12}{|c|}{$\begin{array}{l}\text { Employment Share in Manufacturing } \\
\text {. }\end{array}$} \\
\hline & OLS & 2 SLS & OLS & 2 SLS & OLS & 2 SLS & OLS & 2 SLS & OLS & 2 SLS & OLS & $2 \mathrm{SLS}$ \\
\hline Weights & \multicolumn{4}{|c|}{1880 , labor share } & \multicolumn{4}{|c|}{1870 , value share } & \multicolumn{4}{|c|}{1880 , value share } \\
\hline Convict Labor (Continuous) & $\begin{array}{c}0.001 \\
(0.002)\end{array}$ & $\begin{array}{c}-0.026^{* * *} \\
(0.010)\end{array}$ & & & $\begin{array}{l}-0.001 \\
(0.002)\end{array}$ & $\begin{array}{c}-0.035^{* *} \\
(0.016)\end{array}$ & & & $\begin{array}{c}0.002 \\
(0.002)\end{array}$ & $\begin{array}{l}-0.032^{*} \\
(0.019)\end{array}$ & & \\
\hline Convict Labor (Discrete) & & & $\begin{array}{l}-0.001 \\
(0.001)\end{array}$ & $\begin{array}{c}-0.005^{* * *} \\
(0.002)\end{array}$ & & & $\begin{array}{l}-0.003 * \\
(0.001)\end{array}$ & $\begin{array}{c}-0.005^{* * *} \\
(0.002)\end{array}$ & & & $\begin{array}{l}-0.001 \\
(0.001)\end{array}$ & $\begin{array}{c}-0.006 * * * \\
(0.002)\end{array}$ \\
\hline $\begin{array}{l}\text { Observations } \\
\text { F-stat of excl inst }\end{array}$ & 1,603 & 1,603 & 1,602 & 1,602 & 1,603 & 1,603 & 1,603 & 1,603 & 1,603 & 1,603 & 1,603 & 1,603 \\
\hline F-stat. of excl. inst. & & 21.22 & & 54.63 & & 17.57 & & 73.50 & & 6.25 & & 55.49 \\
\hline
\end{tabular}

Note: In Columns I to IV, $\lambda_{i, c}$ is a labor share of industry $i$ in county $c$ in 1880 . In Columns $\mathrm{V}$ to VIII, $\lambda_{i, c}$ is a value share of industry $i \$$ in county $c$ in 1870. In Columns IX to XII, $\lambda_{i, c}$ is a value share of industry $i$ in county $c$ in 1880. Exposure to convict labor is normalized. All columns contain a constant and the following control variables (in changes, 1870-1880): $\log$ manufacturing output, $\log$ total population, urban share, share of Black population, share of foreign-born population, log value of farms, log county's area, latitude, and longitude. Robust, clustered-by-state standard errors are in parentheses. *** $\mathrm{p}<0.01,{ }^{* *} \mathrm{p}<0.05,{ }^{*} \mathrm{p}<0.1$ 


\section{Alternative Iceberg Costs}

Here I show the robustness of my results to alternative iceberg costs. First, I allow for different $\sigma$. Table C5 shows the results for a continuous specification with $\sigma=0.5$ and $\sigma=2$ :

$$
\begin{aligned}
& C L_{c, 1886}^{\text {continuous }}=\sum_{i \in I}\left(\lambda_{i, c} \times \sum_{k \in K} \frac{\ln \left(\text { Value of goods produced } \text { pres,1886 }_{i, k}\right)}{\sqrt{\left(\text { Trade } \operatorname{costs}_{c, k}\right)}}\right) \text {, and }
\end{aligned}
$$

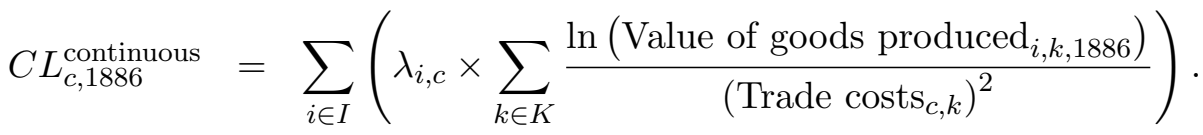

Table C5-Convict labor and local labor markets: Alternative $\sigma$

\begin{tabular}{|c|c|c|c|c|c|c|}
\hline \multirow[t]{2}{*}{ 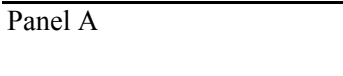 } & \multicolumn{6}{|c|}{$\begin{array}{l}\text { Introduction of Convict Labor (1870-1886) } \\
\end{array}$} \\
\hline & $\mathrm{I}$ & II & III & IV & $\mathrm{V}$ & $\mathrm{VI}$ \\
\hline \multirow[t]{2}{*}{ Outcome (1880-1900): } & \multicolumn{2}{|c|}{$\begin{array}{l}\Delta \text { log Wage in } \\
\text { Manufacturing }\end{array}$} & \multicolumn{2}{|c|}{$\begin{array}{l}\Delta \text { Labor-Force } \\
\text { Participation }\end{array}$} & \multicolumn{2}{|c|}{$\begin{array}{l}\Delta \text { Employment Share } \\
\text { in Manufacturing }\end{array}$} \\
\hline & OLS & 2 SLS & OLS & 2 SLS & OLS & 2 SLS \\
\hline $\begin{array}{l}\text { Convict Labor (Continuous) } \\
(\delta=0.5)\end{array}$ & $\begin{array}{c}-0.014 * * \\
(0.006)\end{array}$ & $\begin{array}{l}-0.0623^{*} \\
(0.0368)\end{array}$ & $\begin{array}{l}-0.002 \\
(0.002)\end{array}$ & $\begin{array}{c}-0.0400^{* *} \\
(0.0173)\end{array}$ & $\begin{array}{l}-0.000 \\
(0.002)\end{array}$ & $\begin{array}{l}-0.0166^{*} \\
(0.00848)\end{array}$ \\
\hline Observations & 1,607 & 1,603 & 1,607 & 1,603 & 1,607 & 1,603 \\
\hline F-stat. of excl. inst. & & 8.95 & & 21.48 & & 10.56 \\
\hline Panel B & \multicolumn{6}{|c|}{ 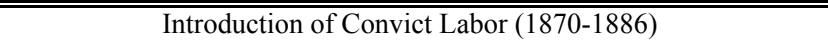 } \\
\hline \multirow{3}{*}{ Outcome (1880-1900): } & $\mathrm{I}$ & II & III & IV & $\mathrm{V}$ & VI \\
\hline & \multicolumn{2}{|c|}{$\begin{array}{l}\Delta \text { log Wage in } \\
\text { Manufacturing }\end{array}$} & \multicolumn{2}{|c|}{$\begin{array}{l}\Delta \text { Labor-Force } \\
\text { Participation }\end{array}$} & \multicolumn{2}{|c|}{$\begin{array}{l}\Delta \text { Employment Share } \\
\text { in Manufacturing }\end{array}$} \\
\hline & OLS & 2 SLS & OLS & 2 SLS & OLS & 2 SLS \\
\hline $\begin{array}{l}\text { Convict Labor (Continuous) } \\
(\delta=2)\end{array}$ & $\begin{array}{l}-0.005 \\
(0.004)\end{array}$ & $\begin{array}{l}-0.0138^{*} \\
(0.00805)\end{array}$ & $\begin{array}{l}-0.002 \\
(0.002)\end{array}$ & $\begin{array}{c}-0.0104^{* * *} \\
(0.00347)\end{array}$ & $\begin{array}{c}-0.002^{* *} \\
(0.001)\end{array}$ & $\begin{array}{c}-0.00418^{* *} \\
(0.00189)\end{array}$ \\
\hline $\begin{array}{l}\text { Observations } \\
\text { F-stat. of excl. inst. }\end{array}$ & 1,607 & $\begin{array}{l}1,603 \\
41.56\end{array}$ & 1,607 & $\begin{array}{l}1,603 \\
42.31\end{array}$ & 1,607 & $\begin{array}{l}1,603 \\
44.70\end{array}$ \\
\hline
\end{tabular}

Note: In Panel A, $\sigma=0.5$. In Panel $\mathrm{B}, \sigma=2$. Exposure to convict labor is normalized. All columns contain a constant. The following variables are used as controls (in changes): ln of total population, urban share, share of Black population, share of foreign-born population, ln of manufacturing output, ln of value of farm products, and log of market access (the change and the base level of 1870). All columns have a corresponding lagged outcome variable (level) as a control. Robust, clustered-by-state standard errors are in parentheses. ${ }^{* * *} \mathrm{p}<0.01,{ }^{* *} \mathrm{p}<0.05,{ }^{*} \mathrm{p}<0.1$

Both specification yield strong and significant results consistent with the baseline. The specification in Panel A (with $\sigma=0.5$ ) allows exposure to convict labor 
to be more nationwide (like competition with imported goods), and the coefficients move toward those in specification with only industry weights (Table C10). The specification in Panel $\mathrm{B}$ (with $\sigma=2$ ) assumes that the shock is more local and the size of the coefficient moves toward estimates in the baseline discrete specification (Panel B of Table 1).

TABle C6-Convict LABor AND LOCAL LABor MARkets: Specifications With Weighting By DISTANCE-TO-PRISON

\begin{tabular}{|c|c|c|c|c|c|c|}
\hline \multirow{4}{*}{$\begin{array}{l}\text { Panel A } \\
\text { Outcome (1880-1900): }\end{array}$} & \multicolumn{6}{|c|}{ Introduction of Convict Labor (1870-1886) } \\
\hline & $\mathrm{I}$ & II & III & IV & $\mathrm{V}$ & VI \\
\hline & \multicolumn{2}{|c|}{$\begin{array}{l}\Delta \text { log Wage in } \\
\text { Manufacturing }\end{array}$} & \multicolumn{2}{|c|}{$\begin{array}{l}\Delta \text { Labor-Force } \\
\text { Participation }\end{array}$} & \multicolumn{2}{|c|}{$\begin{array}{c}\Delta \text { Employment Share in } \\
\text { Manufacturing }\end{array}$} \\
\hline & OLS & $2 \mathrm{SLS}$ & OLS & $2 \mathrm{SLS}$ & OLS & $2 \mathrm{SLS}$ \\
\hline Convict Labor (Continuous) & $\begin{array}{c}-0.011 * * * \\
(0.003)\end{array}$ & $\begin{array}{c}-0.023 * * * \\
(0.006)\end{array}$ & $\begin{array}{c}-0.003 * * * \\
(0.001)\end{array}$ & $\begin{array}{c}-0.004 * * \\
(0.002)\end{array}$ & $\begin{array}{c}-0.005 * * * \\
(0.001)\end{array}$ & $\begin{array}{c}-0.008 * * \\
(0.003)\end{array}$ \\
\hline R-squared & 0.238 & 0.224 & 0.036 & 0.033 & 0.113 & 0.105 \\
\hline Kleibergen-Paap F-stat & & 12.8 & & 15.6 & & 13.6 \\
\hline Observations & 1,954 & 1,954 & 2,122 & 2,122 & 2,226 & 2,226 \\
\hline Panel B & \multicolumn{6}{|c|}{ Introduction of Convict Labor (1870-1886): w Pre-trend } \\
\hline \multirow{3}{*}{ Outcome (1880-1900): } & I & II & III & IV & $\mathrm{V}$ & VI \\
\hline & \multicolumn{2}{|c|}{$\begin{array}{l}\Delta \text { log Wage in } \\
\text { Manufacturing }\end{array}$} & \multicolumn{2}{|c|}{$\begin{array}{c}\Delta \text { Labor-Force } \\
\text { Participation }\end{array}$} & \multicolumn{2}{|c|}{$\begin{array}{c}\Delta \text { Employment Share in } \\
\text { Manufacturing }\end{array}$} \\
\hline & OLS & 2SLS & OLS & 2SLS & OLS & 2SLS \\
\hline Convict Labor (Continuous) & $\begin{array}{c}-0.008 * * * \\
(0.002)\end{array}$ & $\begin{array}{c}-0.020 * * * \\
(0.006)\end{array}$ & $\begin{array}{c}-0.003 * * * \\
(0.001)\end{array}$ & $\begin{array}{c}-0.004 * * \\
(0.002)\end{array}$ & $\begin{array}{c}-0.004 * * * \\
(0.001)\end{array}$ & $\begin{array}{c}-0.007 * * \\
(0.004)\end{array}$ \\
\hline$\Delta \mathrm{Y}(1860-1870)$ & $\mathrm{X}$ & $\mathrm{X}$ & $\mathrm{X}$ & $\mathrm{X}$ & $\mathrm{X}$ & $\mathrm{X}$ \\
\hline R-squared & 0.351 & 0.338 & 0.038 & 0.035 & 0.135 & 0.128 \\
\hline Kleibergen-Paap F-stat & & 12.3 & & 15.6 & & 12.0 \\
\hline Observations & 1,933 & 1,933 & 1,930 & 1,930 & 2,061 & 2,061 \\
\hline
\end{tabular}

Note: Exposure to convict labor is normalized. All columns contain a constant. The following variables are used as controls (in changes): ln of total population, urban share, share of Black population, share of women, share of foreign-born population, ln of manufacturing output, ln of value of farm products, and $\log$ of market access (the change and the base level of 1870). All columns have a corresponding lagged outcome variable (level) as a control. Robust, clustered-by-state standard errors are in parentheses. $* * *$ $\mathrm{p}<0.01, * * \mathrm{p}<0.05,{ }^{*} \mathrm{p}<0.1$

In Table C6, I show results for the specification where I use weighting by distance to prison, instead of trade costs. This specification is less precise than one with the costs of trade, but it may be favorable if one fears that the baseline measure (equation 2) distorts the effect of convict labor due to correlation of trade costs with unobserved spatial confounders (not addressed by market access controls). The main explanatory variable is: 


$$
C L_{c, 1886}^{\text {continuous }}=\sum_{i \in I}\left(\lambda_{i, c} \times \sum_{p \in P} \frac{\ln \left(\text { Value of goods produced }_{i, p, 1886}\right)}{\left(\text { Distance }_{c, p}\right)}\right),
$$

where $P$ is a set of prisons that existed in 1886, and Distance c $_{c, p}$ is the distance (in $\mathrm{km}$ ) from prison $p$ to county c's centroid. I also use distance-to-prison in the construction of the instrument: Old Prisons ${ }_{c, 1870}=\sum_{p \in P}\left(\frac{\ln \left(\text { Old prison capacity }_{p}\right)}{\left(\text { Distance }_{c, p}\right)}\right)$.

Here I only show the specification with (Panel B) and without (Panel A) changes in dependent variables, to show the absence of a pretrend. Figure $\mathrm{C} 1$ shows the linear relationship between the explanatory variable and the instrument in the first stage.

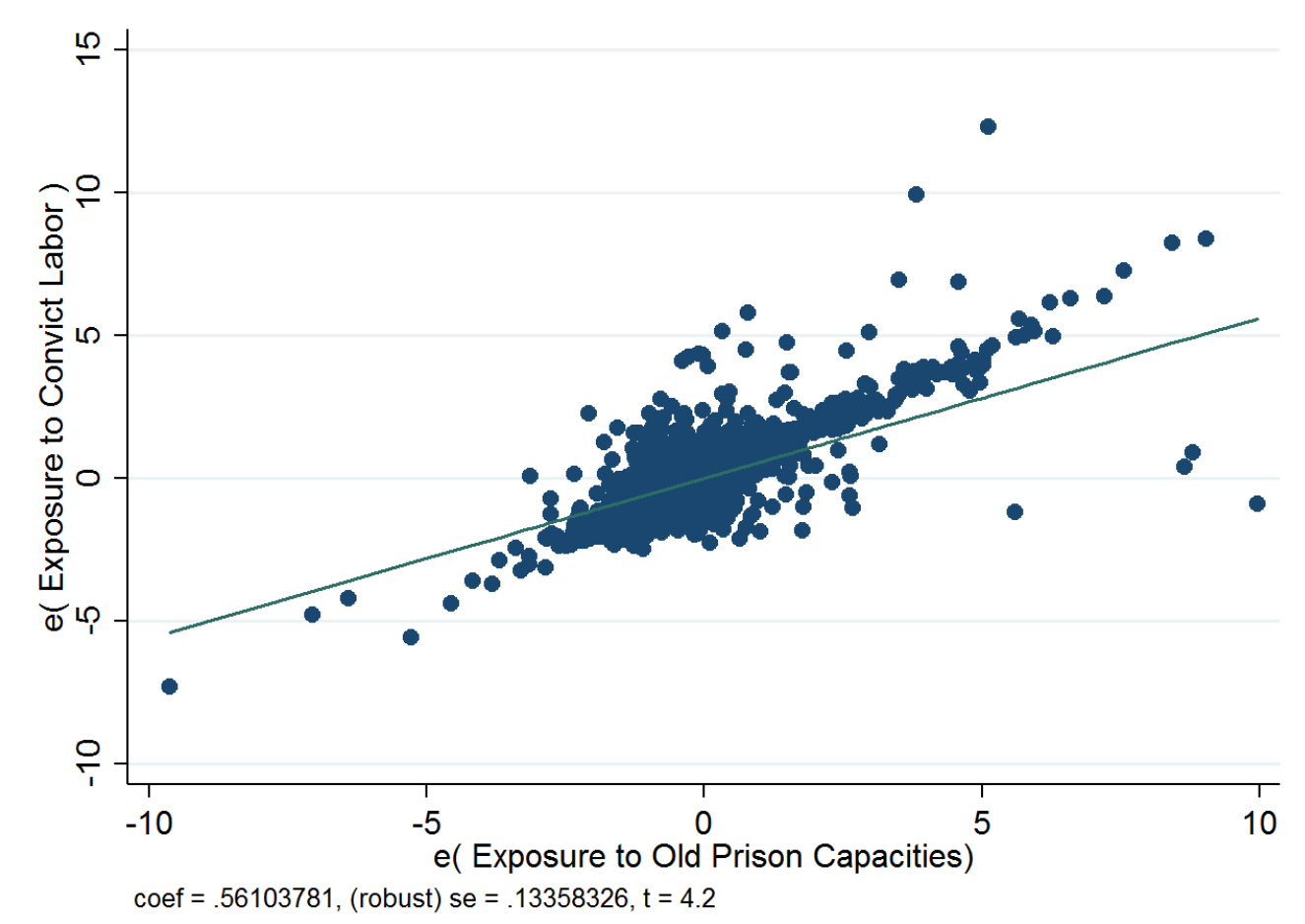

Figure C1. The first stage: Residual plot (weighted by distance-to-Prison instead of by trade COSTS)

In Table C7 I report continuous specification with values of convict labor in dollars instead of log value of prison-made goods. I do not use values instead 
of logs in the discrete specification. As I have a log-linear relationship between the treatment and outcome, the log of treatment helps me not to have extremely large values. The main explanatory variable is:

$$
C L_{c, 1886}^{\text {continuous }}=\sum_{i \in I}\left(\lambda_{i, c} \times \sum_{k \in K} \frac{\text { Value of goods produced in prisons }}{i, k, 1886}\right) .
$$

TABle C7-Convict labor and local labor markets: Specifications without log

\begin{tabular}{|c|c|c|c|c|c|c|}
\hline & \multicolumn{6}{|c|}{ Introduction of Convict Labor (1870-1886) } \\
\hline \multirow{3}{*}{ Outcome (1880-1900): } & $\mathrm{I}$ & II & III & IV & $\mathrm{V}$ & VI \\
\hline & \multicolumn{2}{|c|}{$\begin{array}{l}\Delta \text { log Wage in } \\
\text { Manufacturing }\end{array}$} & \multicolumn{2}{|c|}{$\begin{array}{l}\Delta \text { Labor-Force } \\
\text { Participation }\end{array}$} & \multicolumn{2}{|c|}{$\begin{array}{c}\Delta \text { Employment Share } \\
\text { in Manufacturing }\end{array}$} \\
\hline & OLS & 2SLS & OLS & $2 \mathrm{SLS}$ & OLS & $2 \mathrm{SLS}$ \\
\hline Convict Labor (continuous) & $\begin{array}{l}-0.012 * \\
(0.007)\end{array}$ & $\begin{array}{l}-0.073 * \\
(0.043)\end{array}$ & $\begin{array}{l}-0.001 \\
(0.003)\end{array}$ & $\begin{array}{l}-0.015^{*} \\
(0.008)\end{array}$ & $\begin{array}{l}-0.000 \\
(0.002)\end{array}$ & $\begin{array}{l}-0.041 * * \\
(0.019)\end{array}$ \\
\hline First-stage instrument's coef. & & $\begin{array}{c}0.087 * * * \\
(0.031)\end{array}$ & & $\begin{array}{c}0.099 * * * \\
(0.034)\end{array}$ & & $\begin{array}{c}0.091 * * * \\
(0.023)\end{array}$ \\
\hline R-squared & 0.269 & 0.23 & 0.050 & 0.02 & 0.086 & -0.12 \\
\hline F-stat. of excl. inst. & & 7.99 & & 8.50 & & 16.44 \\
\hline Observations & 1,603 & 1,603 & 1,603 & 1,603 & 1,603 & 1,603 \\
\hline
\end{tabular}

Note: Exposure to convict labor is normalized. All columns contain a constant. The following variables are used as controls (in changes): ln of total population, urban share, share of Black population, share of women, share of foreign-born population, ln of manufacturing output, ln of value of farm products, and log of market access (the change and the base level of 1870). All columns have a corresponding lagged outcome variable (level) as a control. Robust, clustered-by-state standard errors are in parentheses. *** $\mathrm{p}<0.01, * * \mathrm{p}<0.05,{ }^{*} \mathrm{p}<0.1$ 


\section{In-STAte PRisons}

Table C8 contains results for the specification with the continuous measure of convict-labor exposure that uses only the value of goods produced in prisons in the county's state:

$$
C L_{c(s), 1886}^{\text {continuous }}=\sum_{i \in I}\left(\lambda_{i, c} \times \sum_{k \in K_{s}} \frac{\ln \left(\text { Value of goods produced } \text { pred }_{i, k}\right. \text { (1886) }}{\left(\text { Trade } \operatorname{costs}_{c, k}\right)^{\sigma}}\right),
$$

where index $c(s)$ indicates county $c$ in state $s$, and convict labor is summed over all counties $\left(K_{s}\right)$ that have convict labor in state $s$. While this specification is unambiguous that the standard errors should be clustered by state, it misses a lot of variation in exposure to convict labor and assumes that its effect is very localized.

Table C8 - Convict labor and local labor markets: SPecifications With in-State PRisons only

\begin{tabular}{|c|c|c|c|c|c|c|}
\hline \multirow[t]{2}{*}{$\overline{\text { Panel A }}$} & \multicolumn{6}{|c|}{ Introduction of Convict Labor (1870-1886) } \\
\hline & $\mathrm{I}$ & II & III & IV & $\mathrm{V}$ & VI \\
\hline \multirow[t]{2}{*}{ Outcome (1880-1900): } & \multicolumn{2}{|c|}{$\begin{array}{l}\Delta \text { log Wage in } \\
\text { Manufacturing }\end{array}$} & \multicolumn{2}{|c|}{$\begin{array}{l}\Delta \text { Labor-Force } \\
\text { Participation }\end{array}$} & \multicolumn{2}{|c|}{$\begin{array}{l}\Delta \text { Employment Share } \\
\text { in Manufacturing }\end{array}$} \\
\hline & OLS & 2SLS & OLS & 2SLS & OLS & 2 SLS \\
\hline Convict Labor (Continuous) & $\begin{array}{l}-0.016^{*} \\
(0.009)\end{array}$ & $\begin{array}{l}-0.0517 * \\
(0.0282)\end{array}$ & $\begin{array}{l}-0.001 \\
(0.002)\end{array}$ & $\begin{array}{l}-0.0273 * \\
(0.0159)\end{array}$ & $\begin{array}{l}0.004 * \\
(0.002)\end{array}$ & $\begin{array}{l}-0.0103^{*} \\
(0.00562)\end{array}$ \\
\hline R-squared & 0.218 & 0.18 & 0.068 & -0.18 & 0.043 & -0.07 \\
\hline Kleibergen-Paap F-stat & & 10.56 & & 6.80 & & 10.75 \\
\hline Observations & 1,831 & 1,831 & 1,831 & 1,831 & 1,831 & 1,831 \\
\hline \multirow[t]{2}{*}{ 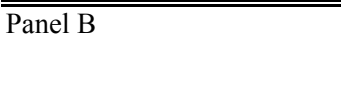 } & \multicolumn{6}{|c|}{ Introduction of Convict Labor (1870-1886): with Pre-trend } \\
\hline & $\mathrm{I}$ & II & III & IV & $\mathrm{V}$ & VI \\
\hline Outcome (1880-1900): & \multicolumn{2}{|c|}{$\begin{array}{l}\Delta \text { log Wage in } \\
\text { Manufacturing }\end{array}$} & \multicolumn{2}{|c|}{$\begin{array}{l}\Delta \text { Labor-Force } \\
\text { Participation }\end{array}$} & \multicolumn{2}{|c|}{$\begin{array}{c}\Delta \text { Employment Share } \\
\text { in Manufacturing }\end{array}$} \\
\hline & OLS & 2SLS & OLS & 2SLS & OLS & 2 SLS \\
\hline Convict Labor (Continuous) & $\begin{array}{l}-0.015^{*} \\
(0.009)\end{array}$ & $\begin{array}{l}-0.0334^{*} \\
(0.0197)\end{array}$ & $\begin{array}{l}-0.001 \\
(0.002)\end{array}$ & $\begin{array}{l}-0.0249 \\
(0.0161)\end{array}$ & $\begin{array}{l}0.004^{*} \\
(0.002)\end{array}$ & $\begin{array}{l}-0.00938 * \\
(0.00528)\end{array}$ \\
\hline$\Delta \mathrm{Y}(1860-1870)$ & $\mathrm{X}$ & $\mathrm{X}$ & $\mathrm{X}$ & $\mathrm{X}$ & $\mathrm{X}$ & $\mathrm{X}$ \\
\hline R-squared & 0.239 & 0.23 & 0.086 & -0.13 & 0.056 & -0.04 \\
\hline Kleibergen-Paap F-stat & & 11.88 & & 6.56 & & 11.26 \\
\hline Observations & 1,592 & 1,592 & 1,592 & 1,592 & 1,592 & 1,592 \\
\hline
\end{tabular}

Note: Exposure to convict labor is normalized. All columns contain a constant. The following variables are used as controls (in changes): ln of total population, urban share, share of Black population, share of foreign-born population, ln of manufacturing output, ln of value of farm products, and log of market access (the change and the base level of 1870). All columns have a corresponding lagged outcome variable (level) as a control. Robust, clustered-by-state standard errors are in parentheses. ${ }^{* * *} \mathrm{p}<0.01,{ }^{* *} \mathrm{p}<$ $0.05, * \mathrm{p}<0.1$ 


\section{Only Trade Cost or Only Industry Weights}

My main dependent variable depends both on distance and on industry composition. In Table C9, I show that my results do not depend on industry weighting. I use the following measures of exposure to convict labor:

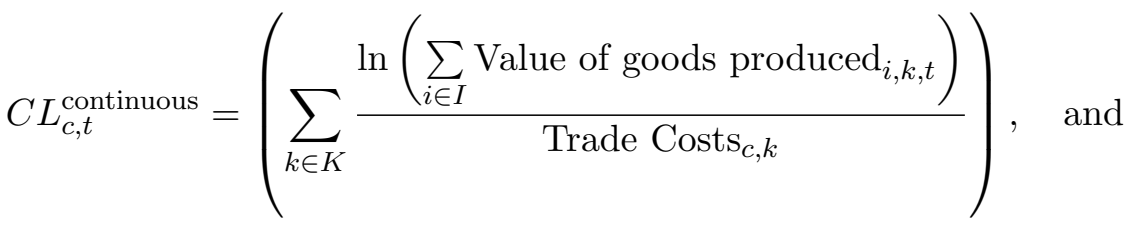

$$
\begin{aligned}
& C L_{c, t}^{\text {discrete }}=\ln \left(\sum_{p \in K}\left(\sum_{i \in I} \text { Value of goods } \operatorname{produces}_{i, k, t}\right)\right) \text {. }
\end{aligned}
$$

Table C9-Convict labor and local labor markets: Specifications with Weighting by trade COSTS ONLY

\begin{tabular}{|c|c|c|c|c|c|c|}
\hline \multirow[t]{2}{*}{ Panel A } & \multicolumn{6}{|c|}{ Introduction of Convict Labor (1870-1886) } \\
\hline & $\mathrm{I}$ & II & III & IV & $\mathrm{V}$ & VI \\
\hline \multirow[t]{2}{*}{ Outcome (1880-1900): } & \multicolumn{2}{|c|}{$\begin{array}{l}\Delta \text { log Wage in } \\
\text { Manufacturing }\end{array}$} & \multicolumn{2}{|c|}{$\begin{array}{l}\Delta \text { Labor-Force } \\
\text { Participation }\end{array}$} & \multicolumn{2}{|c|}{$\begin{array}{c}\Delta \text { Employment Share } \\
\text { in Manufacturing }\end{array}$} \\
\hline & OLS & 2SLS & OLS & 2SLS & OLS & 2SLS \\
\hline Convict Labor (Continuous) & $\begin{array}{l}-0.056^{*} \\
(0.030)\end{array}$ & $\begin{array}{c}-0.13^{* * *} \\
(0.05)\end{array}$ & $\begin{array}{l}-0.056^{*} \\
(0.030)\end{array}$ & $\begin{array}{c}-0.13 * * * \\
(0.05)\end{array}$ & $\begin{array}{l}-0.009 \\
(0.025)\end{array}$ & $\begin{array}{c}-0.0554 * * \\
(0.0230)\end{array}$ \\
\hline R-squared & 0.094 & 0.08 & 0.094 & 0.08 & 0.050 & 0.04 \\
\hline Observations & 1,603 & 1,603 & 1,603 & 1,603 & 1,603 & 1,603 \\
\hline \multirow[t]{2}{*}{ Panel B } & \multicolumn{6}{|c|}{ Introduction of Convict Labor (1870-1886) } \\
\hline & $\mathrm{I}$ & II & III & IV & $\mathrm{V}$ & VI \\
\hline \multirow[t]{2}{*}{ Outcome (1880-1900): } & \multicolumn{2}{|c|}{$\begin{array}{l}\Delta \text { log Wage in } \\
\text { Manufacturing }\end{array}$} & \multicolumn{2}{|c|}{$\begin{array}{c}\Delta \text { Labor-Force } \\
\text { Participation }\end{array}$} & \multicolumn{2}{|c|}{$\begin{array}{c}\Delta \text { Employment Share } \\
\text { in Manufacturing }\end{array}$} \\
\hline & OLS & $2 \mathrm{SLS}$ & OLS & 2SLS & OLS & 2SLS \\
\hline Convict Labor (Discrete) & $\begin{array}{c}-0.005^{* *} \\
(0.002)\end{array}$ & $\begin{array}{l}-0.004 * \\
(0.003)\end{array}$ & $\begin{array}{l}-0.001 \\
(0.001)\end{array}$ & $\begin{array}{c}-0.004 * * * \\
(0.00)\end{array}$ & $\begin{array}{l}-0.0002 \\
(0.001)\end{array}$ & $\begin{array}{c}-0.0013 * * \\
(0.0006)\end{array}$ \\
\hline R-squared & 0.238 & 0.24 & 0.089 & 0.08 & 0.049 & 0.04 \\
\hline F-stat. of excl. inst. & & 134.91 & & 116.56 & & 152.45 \\
\hline Observations & 1,603 & 1,603 & 1,603 & 1,603 & 1,603 & 1,603 \\
\hline
\end{tabular}

Note: Both values of exposure to convict labor are normalized. All columns contain constant, county, and decade fixed effects. The following variables are used as controls: ln of total population, urban share, share of Black population, share of women, share of foreign-born population, ln of manufacturing output, employment share in manufacturing, employment share in agriculture, ln of value of farm products, number of dwellings. Robust, clustered-by-state standard errors are in parentheses. ${ }^{* * *} \mathrm{p}<0.01,{ }^{* *} \mathrm{p}$ $<0.05,{ }^{*} \mathrm{p}<0.1$ 
Table C10 also reports results of the specification with only industry weighting:

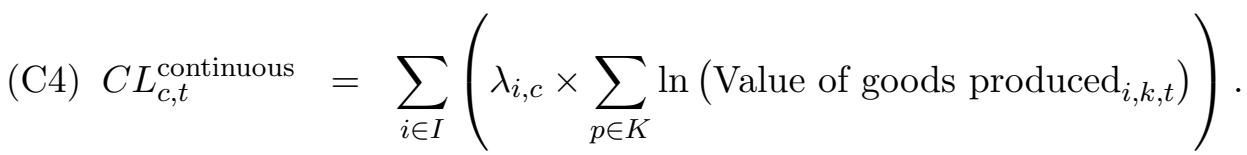

Table C10 - Convict labor and local labor markets: Specifications with Weighting by indusTRY ONLY

\begin{tabular}{|c|c|c|c|c|c|c|}
\hline \multirow[t]{2}{*}{ 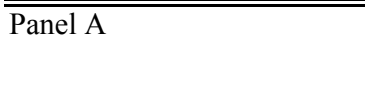 } & \multicolumn{6}{|c|}{ Introduction of Convict Labor (1870-1886) } \\
\hline & $\mathrm{I}$ & II & III & IV & $\mathrm{V}$ & $\mathrm{VI}$ \\
\hline \multirow[t]{2}{*}{ Outcome (1880-1900): } & \multicolumn{2}{|c|}{$\begin{array}{l}\Delta \text { log Wage in } \\
\text { Manufacturing }\end{array}$} & \multicolumn{2}{|c|}{$\begin{array}{l}\Delta \text { Labor-Force } \\
\text { Participation }\end{array}$} & \multicolumn{2}{|c|}{$\begin{array}{c}\Delta \text { Employment Share } \\
\text { in Manufacturing }\end{array}$} \\
\hline & OLS & 2SLS & OLS & 2SLS & OLS & 2SLS \\
\hline Convict Labor (Continuous) & $\begin{array}{c}-0.04 * * * \\
(0.007)\end{array}$ & $\begin{array}{l}-0.09 * * \\
(0.0423)\end{array}$ & $\begin{array}{c}0.001 \\
(0.003)\end{array}$ & $\begin{array}{l}-0.021 * * * \\
(0.00702)\end{array}$ & $\begin{array}{l}-0.002 \\
(0.002)\end{array}$ & $\begin{array}{l}-0.009 * * * \\
(0.00364)\end{array}$ \\
\hline R-squared & 0.237 & 0.19 & 0.066 & -0.01 & 0.031 & 0.02 \\
\hline Kleibergen-Paap F-stat & & 23.1 & & 72.1 & & 147.6 \\
\hline Observations & 1,886 & 1,886 & 1,886 & 1,886 & 1,886 & 1,886 \\
\hline \multirow[t]{2}{*}{ Panel B } & \multicolumn{6}{|c|}{ Introduction of Convict Labor (1870-1886): with Pre-trend } \\
\hline & $\mathrm{I}$ & II & III & IV & $\mathrm{V}$ & $\mathrm{VI}$ \\
\hline Outcome (1880-1900): & \multicolumn{2}{|c|}{$\begin{array}{l}\Delta \text { log Wage in } \\
\text { Manufacturing }\end{array}$} & \multicolumn{2}{|c|}{$\begin{array}{l}\Delta \text { Labor-Force } \\
\text { Participation }\end{array}$} & \multicolumn{2}{|c|}{$\begin{array}{c}\Delta \text { Employment Share } \\
\text { in Manufacturing }\end{array}$} \\
\hline & OLS & 2SLS & OLS & 2SLS & OLS & 2SLS \\
\hline Convict Labor (Continuous) & $\begin{array}{c}-0.04 * * * \\
(0.007)\end{array}$ & $\begin{array}{c}-0.09 * \\
(0.0460)\end{array}$ & $\begin{array}{c}0.004 \\
(0.003)\end{array}$ & $\begin{array}{l}-0.022 * * * \\
(0.00756)\end{array}$ & $\begin{array}{l}-0.002 \\
(0.002)\end{array}$ & $\begin{array}{l}-0.009 * * \\
(0.00380)\end{array}$ \\
\hline$\Delta \mathrm{Y}(1860-1870)$ & $\mathrm{X}$ & $\mathrm{X}$ & $\mathrm{X}$ & $\mathrm{X}$ & $\mathrm{X}$ & $\mathrm{X}$ \\
\hline R-squared & 0.262 & 0.22 & 0.084 & -0.02 & 0.044 & 0.03 \\
\hline Kleibergen-Paap F-stat & & 21.8 & & 67.3 & & 158.0 \\
\hline Observations & 1,633 & 1,633 & 1,633 & 1,633 & 1,633 & 1,633 \\
\hline
\end{tabular}

Note: Exposure to convict labor is normalized. All columns contain a constant. The following variables are used as controls (in changes): ln of total population, urban share, share of Black population, share of women, share of foreign-born population, ln of manufacturing output, ln of value of farm products, and log of market access (the change and the base level of 1870). All columns have a corresponding lagged outcome variable (level) as a control. Robust, clustered-by-state standard errors are in parentheses. $* * *$ $\mathrm{p}<0.01,{ }^{* *} \mathrm{p}<0.05,{ }^{*} \mathrm{p}<0.1$ 


\section{Autor, Dorn, And Hanson's (2013) Measure}

In Table C11, for completeness, I also report specification from Autor, Dorn and Hanson (2013). Their measure of exposure to convict labor is as follows:

$(\mathrm{C} 5) C L_{c, 1886}^{\text {continuous }}=\sum_{i \in I}\left(\frac{L_{c, i, t}}{L_{i, t}} \times\left(\right.\right.$ Value of goods $\left.\left.\operatorname{produced}_{i, 1886}\right) / L_{c, t}\right)$,

where convict labor shock is scaled by county $c$ 's labor force $\left(L_{c, t}\right)$ and share of county $c$ in U.S. employment in industry $i\left(\frac{L_{c, i, t}}{L_{i, t}}\right)$ at year $t=1870$.

Table C11-Convict labor and local labor market outcomes: Autor, Dorn and Hanson (2013) MEASURE

\begin{tabular}{|c|c|c|c|c|c|c|}
\hline \multirow[t]{2}{*}{$\begin{array}{l}\text { Panel A } \\
\end{array}$} & \multicolumn{6}{|c|}{ Introduction of Convict Labor (1870-1886) } \\
\hline & $\mathrm{I}$ & II & III & IV & $\mathrm{V}$ & VI \\
\hline \multirow[t]{2}{*}{ Outcome (1880-1900): } & \multicolumn{2}{|c|}{$\begin{array}{l}\Delta \text { log Wage in } \\
\text { Manufacturing }\end{array}$} & \multicolumn{2}{|c|}{$\begin{array}{l}\Delta \text { Labor-Force } \\
\text { Participation }\end{array}$} & \multicolumn{2}{|c|}{$\begin{array}{l}\Delta \text { Employment Share } \\
\text { in Manufacturing }\end{array}$} \\
\hline & OLS & 2SLS & OLS & 2SLS & OLS & 2SLS \\
\hline Convict Labor (Continuous) & $\begin{array}{c}-0.04^{* * * *} \\
(0.007)\end{array}$ & $\begin{array}{l}-0.09^{* *} \\
(0.0423)\end{array}$ & $\begin{array}{c}0.001 \\
(0.003)\end{array}$ & $\begin{array}{l}-0.021^{* * *} \\
(0.00702)\end{array}$ & $\begin{array}{l}-0.002 \\
(0.002)\end{array}$ & $\begin{array}{l}-0.009^{* * *} \\
(0.00364)\end{array}$ \\
\hline R-squared & 0.237 & 0.19 & 0.066 & -0.01 & 0.031 & 0.02 \\
\hline Kleibergen-Paap F-stat & & 23.1 & & 72.1 & & 147.6 \\
\hline Observations & 1,886 & 1,886 & 1,886 & 1,886 & 1,886 & 1,886 \\
\hline \multirow[t]{2}{*}{ Panel B } & \multicolumn{6}{|c|}{ 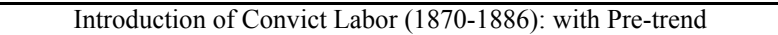 } \\
\hline & $\mathrm{I}$ & II & III & IV & $\mathrm{V}$ & VI \\
\hline Outcome (1880-1900): & \multicolumn{2}{|c|}{$\begin{array}{l}\Delta \text { log Wage in } \\
\text { Manufacturing }\end{array}$} & \multicolumn{2}{|c|}{$\begin{array}{l}\Delta \text { Labor-Force } \\
\text { Participation }\end{array}$} & \multicolumn{2}{|c|}{$\begin{array}{l}\Delta \text { Employment Share } \\
\text { in Manufacturing }\end{array}$} \\
\hline & OLS & 2SLS & OLS & 2 SLS & OLS & 2 SLS \\
\hline Convict Labor (Continuous) & $\begin{array}{c}-0.04 * * * \\
(0.007)\end{array}$ & $\begin{array}{c}-0.09^{*} \\
(0.0460)\end{array}$ & $\begin{array}{c}0.004 \\
(0.003)\end{array}$ & $\begin{array}{l}-0.022^{* * *} \\
(0.00756)\end{array}$ & $\begin{array}{l}-0.002 \\
(0.002)\end{array}$ & $\begin{array}{l}-0.009^{* *} \\
(0.00380)\end{array}$ \\
\hline$\Delta \mathrm{Y}(1860-1870)$ & $\mathrm{X}$ & $\mathrm{X}$ & $\mathrm{X}$ & $\mathrm{X}$ & $\mathrm{X}$ & $\mathrm{X}$ \\
\hline R-squared & 0.262 & 0.22 & 0.084 & -0.02 & 0.044 & 0.03 \\
\hline Kleibergen-Paap F-stat & & 21.8 & & 67.3 & & 158.0 \\
\hline Observations & 1,633 & 1,633 & 1,633 & 1,633 & 1,633 & 1,633 \\
\hline
\end{tabular}

Note: Exposure to convict labor is normalized. All columns contain a constant. The following variables are used as controls (in changes): ln of total population, urban share, share of Black population, share of women, share of foreign-born population, $\ln$ of manufacturing output, $\ln$ of value of farm products, and $\log$ of market access (the change and the base level of 1870). All columns have a corresponding lagged outcome variable (level) as a control. Robust, clustered-by-state standard errors are in parentheses. $* * *$ $\mathrm{p}<0.01,{ }^{* *} \mathrm{p}<0.05,{ }^{*} \mathrm{p}<0.1$

I do not use this measure as a baseline because I do not have county-industrylevel data starting from 1890, and I want my main explanatory variable in this section to be similar to one in the panel specification in Section E. My results also 
hold if I use manufacturing output instead of labor force or if I use $t=1880$, or if I weight value of prison-made goods by trade costs as in baseline specification. These results are available on request.

\section{C3. Allowing Different Intercepts for Each State}

In Table C12, I allow each state to be on its own intercept by adding state fixed effects in the right-hand side of equation 1 :

$$
\Delta y_{c(s), 1880 / 1900}=\alpha+\gamma \Delta C L_{c(s), 1870 / 1886}+\Pi \Delta X_{c(s), 1870 / 1880}+\mu_{s}+\varepsilon_{c(s)},
$$

where $\mu_{s}$ and subscript $c(s)$ indicates that each county $c$ belongs to state $s$. This specification is very restrictive, since now the first stage of the 2SLS regression uses within-state variation in old prison capacities. The resulting coefficients are larger in magnitude than those in the baseline specification, and I chose the specification without state fixed effects as the more conservative one.

Table C12-Convict labor and local labor-market outcomes: Specification with State fixed EFFECTS

\begin{tabular}{|c|c|c|c|c|c|c|c|c|c|c|c|c|}
\hline \multirow{4}{*}{ Outcome (1880-1900): } & \multicolumn{12}{|c|}{ Introduction of convict labor (1870-1886) } \\
\hline & I & II & III & IV & $\mathrm{V}$ & VI & VII & VIII & IX & $\mathrm{X}$ & XI & XII \\
\hline & \multicolumn{4}{|c|}{$\Delta$ log wage in manufacturing } & \multicolumn{4}{|c|}{$\Delta$ Labor-force participation } & \multicolumn{4}{|c|}{$\Delta$ Employment share in manufacturing } \\
\hline & OLS & $2 \mathrm{SLS}$ & OLS & $2 \mathrm{SLS}$ & OLS & $2 \mathrm{SLS}$ & OLS & $2 \mathrm{SLS}$ & OLS & $2 \mathrm{SLS}$ & OLS & $2 \mathrm{SLS}$ \\
\hline $\begin{array}{l}\text { Convict labor } \\
\text { (continuous) }\end{array}$ & $\begin{array}{c}-0.022 * * * \\
(0.005)\end{array}$ & $\begin{array}{c}-0.089^{* * * *} \\
(0.022)\end{array}$ & & & $\begin{array}{l}-0.000 \\
(0.002)\end{array}$ & $\begin{array}{c}-0.03^{* *} \\
(0.01)\end{array}$ & & & $\begin{array}{l}-0.001 \\
(0.002)\end{array}$ & $\begin{array}{l}-0.011 \\
(0.007)\end{array}$ & & \\
\hline $\begin{array}{l}\text { Convict labor } \\
\text { (discrete) }\end{array}$ & & & $\begin{array}{c}-0.005 * * \\
(0.002)\end{array}$ & $\begin{array}{c}-0.034 * * * \\
(0.008)\end{array}$ & & & $\begin{array}{l}-0.002 \\
(0.002)\end{array}$ & $\begin{array}{c}-0.00^{* *} \\
(0.00)\end{array}$ & & & $\begin{array}{l}-0.001^{*} \\
(0.001)\end{array}$ & $\begin{array}{c}-0.002 * \\
(0.0009)\end{array}$ \\
\hline F-stat. of excl. inst. & & 81.12 & & 46.48 & & 45.50 & & 102.92 & & 29.95 & & 109.38 \\
\hline Observations & 1,603 & 1,603 & 1,603 & 1,603 & 1,603 & 1,603 & 1,603 & 1,603 & 1,603 & 1,603 & 1,603 & 1,603 \\
\hline
\end{tabular}

Note: Exposure to convict labor is normalized. All columns contain a constant. The following variables are used as controls (in changes): ln of total population, urban share, share of Black population, share of women, share of foreign-born population, ln of manufacturing output, ln of value of farm products, and $\log$ of market access (the change and the base level of 1870). All columns have a corresponding lagged outcome variable (level) as a control. Robust, clustered-by-state standard errors are in parentheses. $* * *$ $\mathrm{p}<0.01, * * \mathrm{p}<0.05, * \mathrm{p}<0.1$ 
C4. Alternative Standard Errors

Table C13-Convict labor and local labor-market outcomes: Alternative standard errors

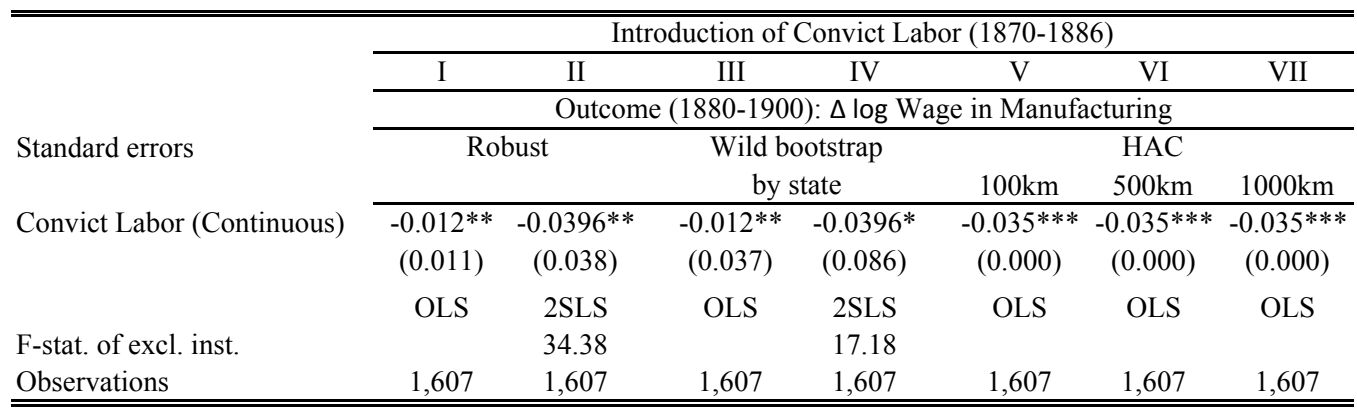

Note: Exposure to convict labor is normalized. All columns contain a constant. The following variables are used as controls (in changes): ln of total population, urban share, share of Black population, share of women, share of foreign-born population, ln of manufacturing output, ln of value of farm products, and $\log$ of market access (the change and the base level of 1870). All columns have a corresponding lagged outcome variable (level) as a control. ${ }^{* * *} \mathrm{p}<0.01,{ }^{* *} \mathrm{p}<0.05,{ }^{*} \mathrm{p}<0.1$

\section{C5. Subsample Analysis}

\section{Extensive vs. Intensive Margin}

The specification with weighting by industry already addressed the point that the effect exists not only for counties that are located near a prison. However, to show that the effect exists not only on extensive margin but also on the intensive margin, Table C14 shows results of the baseline specification on a subsample restricted to only those counties that had a prison at least in one year in my panel. Thus the effect of convict labor is not only the extensive-margin effect of comparing counties with prisons to counties without prisons but also exists on the intensive margin. 
Table C14 - Convict labor and local labor-Market outcomes: Subsample analysis

\begin{tabular}{|c|c|c|c|c|c|c|}
\hline \multirow[t]{2}{*}{$\overline{\text { Panel A }}$} & \multicolumn{6}{|c|}{ 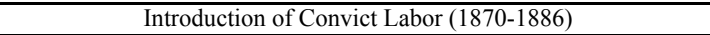 } \\
\hline & $\mathrm{I}$ & II & III & IV & $\mathrm{V}$ & $\mathrm{VI}$ \\
\hline Outcome (1880-1900): & \multicolumn{2}{|c|}{$\begin{array}{l}\Delta \text { log Wage in } \\
\text { Manufacturing }\end{array}$} & \multicolumn{2}{|c|}{$\begin{array}{l}\Delta \text { Labor-Force } \\
\text { Participation }\end{array}$} & \multicolumn{2}{|c|}{$\begin{array}{l}\Delta \text { Employment Share } \\
\text { in Manufacturing }\end{array}$} \\
\hline Convict Labor (Discrete) & $\begin{array}{c}\text { OLS } \\
-0.003 \\
(0.002)\end{array}$ & $\begin{array}{c}\text { 2SLS } \\
-0.017^{*} \\
(0.009)\end{array}$ & $\begin{array}{c}\text { OLS } \\
-0.007^{* * *} \\
(0.001)\end{array}$ & $\begin{array}{c}\text { 2SLS } \\
-0.010^{* *} \\
(0.004)\end{array}$ & $\begin{array}{c}\text { OLS } \\
-0.002^{* *} \\
(0.001)\end{array}$ & $\begin{array}{c}\text { 2SLS } \\
-0.002 \\
(0.003)\end{array}$ \\
\hline $\begin{array}{l}\text { R-squared } \\
\text { F-stat. of excl. inst. } \\
\text { Observations }\end{array}$ & 0.330 & $\begin{array}{c}0.245 \\
6.0 \\
295\end{array}$ & 0.295 & $\begin{array}{c}0.275 \\
5.8 \\
300\end{array}$ & 0.117 & $\begin{array}{c}0.116 \\
5.8 \\
300\end{array}$ \\
\hline \multirow[t]{2}{*}{ Panel B } & \multicolumn{6}{|c|}{ Introduction of Convict Labor (1870-1886) } \\
\hline & $\mathrm{I}$ & II & III & IV & $\mathrm{V}$ & VI \\
\hline \multirow[t]{2}{*}{ Outcome (1880-1900): } & \multicolumn{2}{|c|}{$\begin{array}{l}\Delta \text { log Wage in } \\
\text { Manufacturing }\end{array}$} & \multicolumn{2}{|c|}{$\begin{array}{l}\Delta \text { Labor-Force } \\
\text { Participation }\end{array}$} & \multicolumn{2}{|c|}{$\begin{array}{l}\Delta \text { Employment Share } \\
\text { in Manufacturing }\end{array}$} \\
\hline & OLS & $2 \mathrm{SLS}$ & OLS & $2 \mathrm{SLS}$ & OLS & $2 \mathrm{SLS}$ \\
\hline $\begin{array}{l}\text { Convict Labor (Discrete) } \\
\text { no industry weigths }\end{array}$ & $\begin{array}{c}-0.001^{* *} \\
(0.000)\end{array}$ & $\begin{array}{c}-0.002 * * * \\
(0.001)\end{array}$ & $\begin{array}{c}-0.001 * * * \\
(0.000)\end{array}$ & $\begin{array}{l}-0.001 \\
(0.001)\end{array}$ & $\begin{array}{c}0.000 \\
(0.000)\end{array}$ & $\begin{array}{l}-0.000 \\
(0.000)\end{array}$ \\
\hline R-squared & 0.332 & 0.288 & 0.276 & 0.267 & 0.110 & 0.102 \\
\hline F-stat. of excl. inst. & & 35.9 & & 35.0 & & 35.0 \\
\hline Observations & 295 & 295 & 300 & 300 & 300 & 300 \\
\hline
\end{tabular}

Note: Exposure to convict labor is normalized. All columns contain a constant. The following variables are used as controls (in changes): ln of total population, urban share, share of Black population, share of women, share of foreign-born population, ln of manufacturing output, ln of value of farm products, and $\log$ of market access (the change and the base level of 1870). All columns have a corresponding lagged outcome variable (level) as a control. Robust, clustered-by-state standard errors are in parentheses. $* * *$ $\mathrm{p}<0.01,{ }^{* *} \mathrm{p}<0.05,{ }^{*} \mathrm{p}<0.1$ 


\section{By REGIONS}

Table C15 - Convict labor and local labor-market outcomes: Subsample analysis

\begin{tabular}{|c|c|c|c|c|c|}
\hline \multirow{4}{*}{$\begin{array}{l}\text { Sample } \\
\text { Convict Labor (Continuous) }\end{array}$} & \multicolumn{5}{|c|}{ "Dependent Variable: $\Delta$ log Wage in Manufacturing } \\
\hline & $\mathrm{I}$ & II & III & IV & $\mathrm{V}$ \\
\hline & w/o South & w/o Northeast & w/o Midwest & w/o Far West & w/o Great Plains \\
\hline & $\begin{array}{c}-0.052^{* * *} \\
(0.015)\end{array}$ & $\begin{array}{l}-0.047^{*} \\
(0.024)\end{array}$ & $\begin{array}{c}-0.037 * * * \\
(0.011)\end{array}$ & $\begin{array}{c}-0.030^{* * *} \\
(0.010)\end{array}$ & $\begin{array}{c}-0.043^{* * *} \\
(0.011)\end{array}$ \\
\hline R-squared & 0.272 & 0.194 & 0.209 & 0.249 & 0.232 \\
\hline Kleibergen-Paap F-stat & 8.72 & 3.53 & 12.70 & 11.03 & 12.37 \\
\hline \multirow[t]{2}{*}{ Observations } & 1,175 & 1,715 & 1,305 & 1,830 & 1,791 \\
\hline & \multicolumn{5}{|c|}{ Dependent Variable: $\Delta$ Labor-Force Participation } \\
\hline \multirow{3}{*}{$\begin{array}{l}\text { Sample } \\
\text { Convict Labor (Continuous) }\end{array}$} & I & II & III & IV & $\mathrm{V}$ \\
\hline & w/o South & w/o Northeast & w/o Midwest & w/o Far West & w/o Great Plains \\
\hline & $\begin{array}{l}-0.006 \\
(0.004)\end{array}$ & $\begin{array}{l}-0.004 \\
(0.004)\end{array}$ & $\begin{array}{l}-0.007 \\
(0.005)\end{array}$ & $\begin{array}{l}-0.006 \\
(0.004)\end{array}$ & $\begin{array}{l}-0.007^{*} \\
(0.004)\end{array}$ \\
\hline R-squared & 0.074 & 0.038 & 0.041 & 0.025 & 0.033 \\
\hline Kleibergen-Paap F-stat & 10.51 & 3.84 & 16.04 & 12.99 & 14.99 \\
\hline \multirow[t]{3}{*}{ Observations } & 1,243 & 1,885 & 1,458 & 1,985 & 1,917 \\
\hline & \multicolumn{5}{|c|}{ Dependent Variable: $\Delta$ Employment Share in Manufacturing } \\
\hline & $\mathrm{I}$ & II & III & IV & $\mathrm{V}$ \\
\hline Sample & w/o South & w/o Northeast & w/o Midwest & w/o Far West & w/o Great Plains \\
\hline Convict Labor (Continuous) & $\begin{array}{l}-0.016^{* *} \\
(0.007)\end{array}$ & $\begin{array}{c}0.001 \\
(0.008)\end{array}$ & $\begin{array}{l}-0.016^{*} \\
(0.008)\end{array}$ & $\begin{array}{c}-0.018^{* *} \\
(0.007)\end{array}$ & $\begin{array}{c}-0.016^{* *} \\
(0.007)\end{array}$ \\
\hline R-squared & 0.090 & 0.104 & 0.126 & 0.110 & 0.111 \\
\hline Kleibergen-Paap F-stat & 10.19 & 3.45 & 13.53 & 11.92 & 13.11 \\
\hline Observations & 1,346 & 1,987 & 1,529 & 2,080 & 1,962 \\
\hline
\end{tabular}

Note: Exposure to convict labor is normalized. All columns contain a constant. The following variables are used as controls (in changes): ln of total population, urban share, share of Black population, share of women, share of foreign-born population, ln of manufacturing output, ln of value of farm products, and log of market access (the change and the base level of 1870). All columns have a corresponding lagged outcome variable (level) as a control. Robust, clustered-by-state standard errors are in parentheses. ${ }^{* * *}$ $\mathrm{p}<0.01,{ }^{* *} \mathrm{p}<0.05,{ }^{*} \mathrm{p}<0.1$ 


\section{C6. Placebo}

Table C16 shows the results of placebo regressions. I assume that convicts employed in farming did not compete with manufacturing workers. Thus I expect that the value of convict-labor output in farming will have no adverse effect on manufacturing wages. Neither a continuous nor a discrete specification results in significant estimates. However, the first-stage F-statistics is also low for placebo specifications. A possible explanation is that most farming was done under the convict leasing system, which did not rely on preexisting prison capacities.

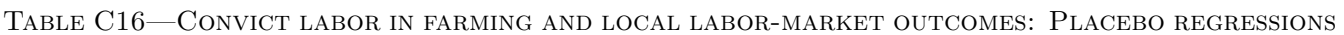

\begin{tabular}{|c|c|c|c|c|c|c|}
\hline \multirow{2}{*}{$\overline{\text { Panel A }}$} & \multicolumn{6}{|c|}{ Introduction of Convict Labor (1870-1886) } \\
\hline & $\mathrm{I}$ & II & III & IV & $\mathrm{V}$ & $\mathrm{VI}$ \\
\hline \multirow[t]{2}{*}{ Outcome (1880-1900): } & \multicolumn{2}{|c|}{$\begin{array}{l}\Delta \text { log Wage in } \\
\text { Manufacturing }\end{array}$} & \multicolumn{2}{|c|}{$\begin{array}{l}\Delta \text { Labor-Force } \\
\text { Participation }\end{array}$} & \multicolumn{2}{|c|}{$\begin{array}{c}\Delta \text { Employment Share } \\
\text { in Manufacturing }\end{array}$} \\
\hline & OLS & 2SLS & OLS & 2SLS & OLS & 2SLS \\
\hline $\begin{array}{l}\text { Convict Labor (Continuous) } \\
\text { in farming }\end{array}$ & $\begin{array}{l}-0.011 \\
(0.009)\end{array}$ & $\begin{array}{c}0.306 \\
(0.563)\end{array}$ & $\begin{array}{c}0.001 \\
(0.002)\end{array}$ & $\begin{array}{l}-0.29 \\
(0.82)\end{array}$ & $\begin{array}{c}0.003 \\
(0.002)\end{array}$ & $\begin{array}{l}0.0957 \\
(0.215)\end{array}$ \\
\hline $\begin{array}{l}\text { R-squared } \\
\text { F-stat. of excl. inst. } \\
\text { Observations }\end{array}$ & 0.237 & $\begin{array}{c}-4.50 \\
0.38 \\
1,603\end{array}$ & 0.086 & $\begin{array}{c}-40.30 \\
0.12 \\
1,603\end{array}$ & 0.057 & $\begin{array}{c}-5.72 \\
0.20 \\
1,603\end{array}$ \\
\hline \multirow[t]{2}{*}{ Panel B } & \multicolumn{6}{|c|}{ Introduction of Convict Labor (1870-1886) } \\
\hline & $\mathrm{I}$ & II & III & IV & $\mathrm{V}$ & VI \\
\hline \multirow[t]{2}{*}{ Outcome (1880-1900): } & \multicolumn{2}{|c|}{$\begin{array}{l}\Delta \text { log Wage in } \\
\text { Manufacturing }\end{array}$} & \multicolumn{2}{|c|}{$\begin{array}{l}\Delta \text { Labor-Force } \\
\text { Participation }\end{array}$} & \multicolumn{2}{|c|}{$\begin{array}{c}\Delta \text { Employment Share } \\
\text { in Manufacturing }\end{array}$} \\
\hline & OLS & 2 SLS & OLS & 2 SLS & OLS & 2SLS \\
\hline $\begin{array}{l}\text { Convict Labor (Discrete) } \\
\text { in farming }\end{array}$ & $\begin{array}{l}-0.005 \\
(0.005)\end{array}$ & $\begin{array}{l}-0.070 \\
(0.058)\end{array}$ & $\begin{array}{c}0.001 \\
(0.001)\end{array}$ & $\begin{array}{l}-0.03 \\
(0.02)\end{array}$ & $\begin{array}{c}0.001 \\
(0.001)\end{array}$ & $\begin{array}{c}-0.0133 \\
(0.00952)\end{array}$ \\
\hline $\begin{array}{l}\text { R-squared } \\
\text { F-stat. of excl. inst. } \\
\text { Observations }\end{array}$ & 0.235 & $\begin{array}{c}-0.43 \\
1.95 \\
1,603\end{array}$ & 0.087 & $\begin{array}{c}-1.47 \\
2.98 \\
1,603\end{array}$ & 0.054 & $\begin{array}{c}-0.45 \\
3.07 \\
1,603\end{array}$ \\
\hline
\end{tabular}

Note: Exposure to convict labor is normalized. All columns contain a constant. The following variables are used as controls (in changes): In of total population, urban share, share of Black population, share of women, share of foreign-born population, ln of manufacturing output, ln of value of farm products, and log of market access (the change and the base level of 1870). All columns have a corresponding lagged outcome variable (level) as a control. Robust, clustered-by-state standard errors are in parentheses. $* * *$ $\mathrm{p}<0.01, * * \mathrm{p}<0.05, * \mathrm{p}<0.1$ 
For the event-study regression, I use the following specification:

$$
y_{c, t}=\alpha_{c}+\beta_{t}+\sum_{k=q}^{K} \gamma_{k} C L_{c, 1886}+\phi X_{c, t}+t \delta_{s}+\varepsilon_{c, t},
$$

where $q$ stands for the number of relative time periods before convict-labor laws were enacted $(t=1870)$ where we expect no effect or opposite sign of the coefficient, and $K$ is the number of relative time periods after the treatment. $y_{c, t}$ is the outcome variable (i.e., log of manufacturing wages, log of population, shares of Black population, and share of urban population); $\alpha_{c}$ and $\beta_{t}$ are county and decade fixed effects, and $t \delta_{s}$ are the state-specific linear trends. Here, I only control for the log of total manufacturing outcome $\left(X_{c, t}\right)$. Standard errors are clustered by state.

For the blue line, $C L_{c, 1886}$ is the log value of prison-made goods produced in county $c$ in 1886. To construct the green line, county's index $c$ represents counties that are adjacent to counties that had prisons. The gray line assumes that counties that are adjacent to counties that adjacent to prisons as treated. 

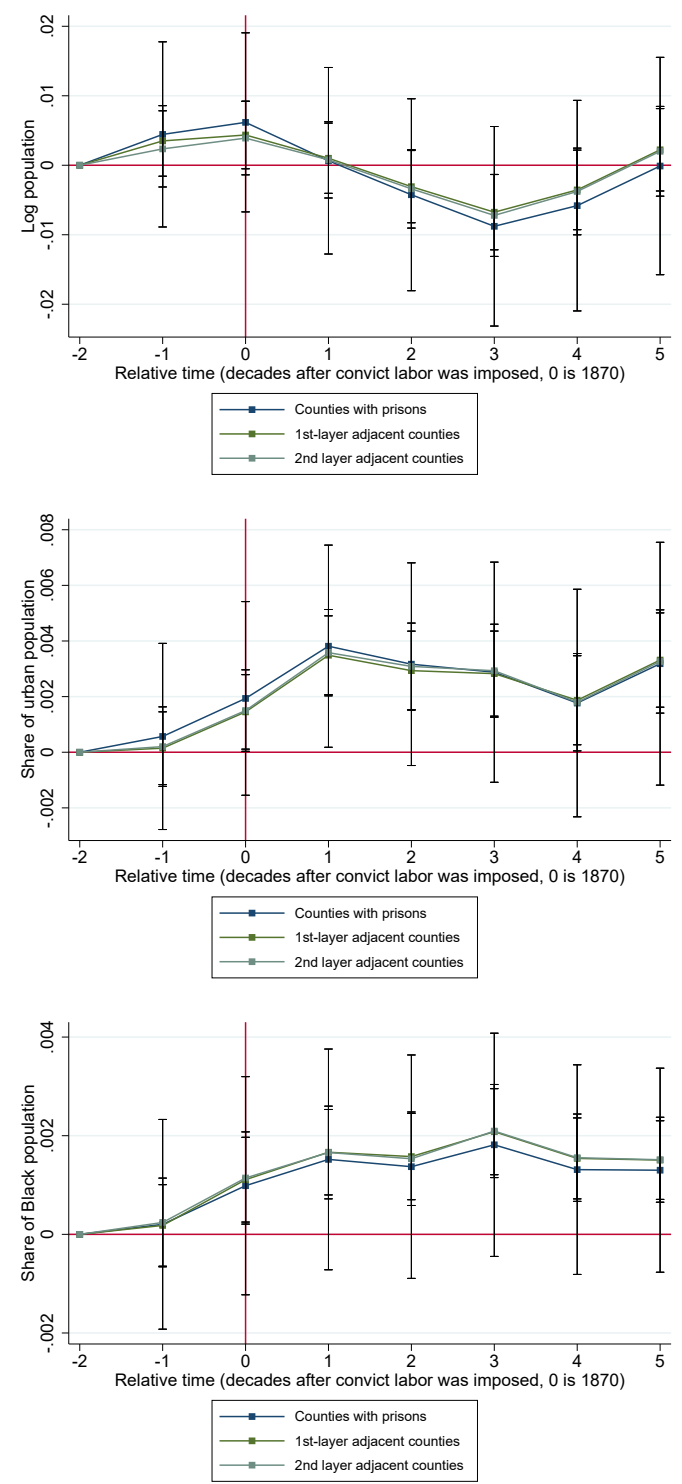

Figure C2. Convict labor and Demographic variables: Event study (Placebo)

Note: Each square is the coefficient of the event-study regression of the log wages in manufacturing on the time-invariant log value of convict-labor output in 1886 in a county, interacted with decade dummies. Relative time (in decades) is plotted on the horizontal axis, such as 1880 is counted as 0 - the first decade when convict labor was imposed. I use state and decade fixed effects, and log manufacturing output in a county as controls. The dark blue line corresponds to a regression where I treat counties that had convict labor in it as treated. The green line treats counties that are adjacent to counties that had prisons. The gray line assumes that counties that are adjacent to counties that adjacent to prisons as treated. My results hold if I double-count adjacent counties that are adjacent to more than one county with prison. $95 \%$ confidence intervals are depicted. 
C\%. Evidence from the Weeks Report

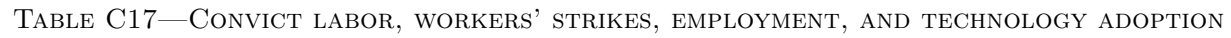

\begin{tabular}{lcccccc}
\hline \hline & I & II & III & IV & V & VI \\
\cline { 2 - 6 } Dependent variable: & Strike & $\begin{array}{c}\text { Strike lost by } \\
\text { workers }\end{array}$ & $\begin{array}{c}1 \text { (convict labor), } \\
1886\end{array}$ & $\begin{array}{c}\text { Months employed } \\
\text { in a year }\end{array}$ & New machinery & $\begin{array}{c}\text { Labor-saving } \\
\text { machinery }\end{array}$ \\
\cline { 2 - 7 } $\begin{array}{l}\text { 1(convict labor), 1886 } \\
\text { (by state \& SIC2) }\end{array}$ & $-0.153^{* *}$ & $0.112^{* *}$ & & $-0.709^{* * *}$ & $0.164^{*}$ & $0.702^{* *}$ \\
Strike (before 1870) & $(0.070)$ & $(0.039)$ & & $(0.243)$ & $(0.078)$ & $(0.250)$ \\
& & & 0.116 & & & \\
R-squared & & & $(0.077)$ & & & \\
Observations & 0.633 & 0.305 & 0.721 & 0.464 & 0.843 & 0.914 \\
\hline \hline
\end{tabular}

Note: All columns contain constant, industry, state, and year fixed effects, and log value of wage. Robust, double-clustered by state and industry standard errors are in parentheses. ${ }^{* * *} \mathrm{p}<0.01,{ }^{* *} \mathrm{p}<0.05,{ }^{*}$ $\mathrm{p}<0.1$

\section{C8. Evidence from Firm-Level Data}

I draw additional evidence for my wage results from firm-level data spanning from 1850 to 1880 . I use state-level representative samples (repeated crosssections) from Atack and Bateman (1999). I estimate the following empirical specification:

(C8) $\ln (\text { Wage })_{f, i, c, t}=\alpha_{c}+\beta_{t}+\xi_{i}+\gamma C L_{i, c, t}+\Pi X_{f, i, c, t}+t \delta_{s}+\varepsilon_{f, i, c, t}$,

where the unit of observation is firm $f$ in industry $i$ in county $c$ at decade $t$. $C L_{i, c, t}$ is the value of prison-made goods in industry $i$, county $c$, and year $t$. I assign a value of convict labor equal to zero for $t=1850,1860$, and 1870, and assign a value of convict labor in 1886 for $t=1880$. I use only a more conservative discrete measure of convict labor, since the sample of firms is representative only on the state level, and spatial treatment may be biased. $\alpha_{c}$ and $\beta_{t}$ are county and decade fixed effects, $t \delta_{s}$ are state-specific linear trends, and $X_{f, i, c, t}$ is a matrix of firm-level controls, such as labor, capital, and 2-digit SIC industry dummies. I cluster standard errors on the state level (in parentheses), and on the stateindustry level, as while convict labor is a state-level policy, the treatment is on the industry level (in brackets).

I present the results in Table C18. Column I contains the specification, with county and year fixed effects, and control for the value of a firm's manufacturing output. A $10 \%$ increase in convict-labor output decreases wages by $0.14 \%$. This 


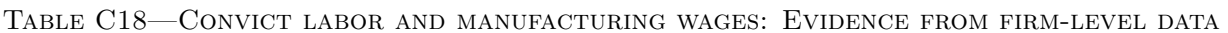

\begin{tabular}{lcccc}
\hline \hline & \multicolumn{1}{c}{ I } & II & III & IV \\
\cline { 2 - 5 } Dependent variable: & \multicolumn{4}{c}{$\log$ of wage in manufacturing } \\
\cline { 2 - 5 } Log convict labor, 1886 & $-0.014^{* *}$ & $-0.014^{* *}$ & $-0.015^{* *}$ & $-0.014^{* *}$ \\
(discrete, by state \& SIC2) & $(0.006)$ & $(0.007)$ & $(0.006)$ & $(0.007)$ \\
& {$[0.007]$} & {$[0.007]$} & {$[0.006]$} & {$[0.007]$} \\
& & & & $\mathrm{X}$ \\
Industry FE & & $\mathrm{X}$ & $\mathrm{X}$ & $\mathrm{X}$ \\
Industry x state FE & & & & $\mathrm{X}$ \\
State-specific trends & & & 0.35 & 0.36 \\
R-squared & 0.28 & 0.32 & 30,066 & 30,066 \\
Observations & 30,066 & 30,066 & & \\
\hline \hline
\end{tabular}

Note: All columns contain a constant and the log value of manufacturing output. Robust, clustered-bystate standard errors are in parentheses. Standard errors clustered by state and two-digit SIC codes are in brackets. *** $\mathrm{p}<0.01, * * \mathrm{p}<0.05, * \mathrm{p}<0.1$

result is remarkably close to the one in Table E2. I add industry dummies in Column II, but the estimates do not change. In Column III, I add an industry-state interaction, in case some state-level laws affected different industries differentially. The magnitude of the coefficient increased slightly, and it remained significant. Finally, in Column IV, I also add state-specific linear trends, but they don't affect the magnitude of the estimate. While this table does not provide causal linkage between convict labor and wages, it provides other evidence that the relationship I have established previously is correct. 
C9. Matching

Table C19-Matching

\begin{tabular}{|c|c|c|c|c|}
\hline \multirow[b]{3}{*}{ Matching } & \multicolumn{4}{|c|}{ Dependent Variable: $\Delta$ log Wage in Manufacturing } \\
\hline & $\mathrm{I}$ & II & III & IV \\
\hline & $\begin{array}{c}\text { Nearest } \\
\text { Neighbor }\end{array}$ & Radius & Kernel-based & Stratification \\
\hline ATT & -0.043 & -0.244 & -0.061 & -0.047 \\
\hline Bootstrapped standard errors & $(0.023)$ & $(0.026)$ & $(0.019)$ & $(0.019)$ \\
\hline t-statistics & -1.89 & -9.4 & -3.18 & -2.4 \\
\hline \# treated & 349 & 35 & 349 & 349 \\
\hline \multirow[t]{3}{*}{ \# controls } & 222 & 1623 & 1688 & 1688 \\
\hline & \multicolumn{4}{|c|}{ Dependent Variable: $\Delta$ Labor-Force Participation } \\
\hline & $\mathrm{I}$ & II & III & IV \\
\hline Matching & $\begin{array}{c}\text { Nearest } \\
\text { Neighbor }\end{array}$ & Radius & Kernel-based & Stratification \\
\hline ATT & -0.010 & -0.011 & -0.012 & -0.011 \\
\hline Bootstrapped standard errors & $(0.010)$ & $(0.008)$ & $(0.009)$ & $(0.008)$ \\
\hline t-statistics & -1.01 & -1.39 & -1.32 & -1.43 \\
\hline \# treated & 349 & 138 & 349 & 349 \\
\hline \multirow[t]{3}{*}{ \# controls } & 228 & 1674 & 1688 & 1688 \\
\hline & \multicolumn{4}{|c|}{ Dependent Variable: $\Delta$ Emp. Share in Manufacturing } \\
\hline & $\mathrm{I}$ & II & III & IV \\
\hline Matching & $\begin{array}{l}\text { Nearest } \\
\text { Neighbor }\end{array}$ & Radius & Kernel-based & Stratification \\
\hline ATT & -0.000 & 0.012 & -0.011 & -0.009 \\
\hline Bootstrapped standard errors & $(0.009)$ & $(0.005)$ & $(0.006)$ & $(0.006)$ \\
\hline t-statistics & -0.009 & -2.30 & -1.64 & -1.28 \\
\hline \# treated & 349 & 280 & 349 & 349 \\
\hline \# controls & 230 & 1685 & 1688 & 1688 \\
\hline
\end{tabular}


C10. Heterogeneous Effects of Convict Labor: Subsample Analysis

Table C20-Convict labor and American women, by geographical region

\begin{tabular}{|c|c|c|c|c|c|c|c|c|c|c|c|c|}
\hline \multirow[t]{2}{*}{ Panel A } & \multicolumn{12}{|c|}{$\begin{array}{l}\text { Introduction of Convict Labor (1870-1886) } \\
\end{array}$} \\
\hline & I & II & III & IV & $\mathrm{V}$ & VI & VII & VIII & IX & $\mathrm{X}$ & $\mathrm{XI}$ & XII \\
\hline Sample & \multicolumn{2}{|c|}{ w/o South } & \multicolumn{2}{|c|}{ w/o West } & \multicolumn{2}{|c|}{ w/o North } & \multicolumn{2}{|c|}{ w/o South } & \multicolumn{2}{|c|}{ w/o West } & \multicolumn{2}{|c|}{ w/o North } \\
\hline \multirow[t]{2}{*}{ Outcome: } & \multicolumn{6}{|c|}{$\Delta$ Wage in Manufacturing } & \multicolumn{6}{|c|}{$\Delta$ Labor-Force Participation } \\
\hline & Female & Male & Female & Male & Female & Male & Female & Male & Female & Male & Female & Male \\
\hline Convict Labor (Continuous) & $\begin{array}{c}-0.069^{* *} \\
(0.030)\end{array}$ & $\begin{array}{c}-0.063^{* * *} \\
(0.012)\end{array}$ & $\begin{array}{c}-0.119^{* * *} \\
(0.031)\end{array}$ & $\begin{array}{c}-0.055^{* * *} \\
(0.009)\end{array}$ & $\begin{array}{l}-0.085 \\
(0.078)\end{array}$ & $\begin{array}{c}-0.039^{* *} \\
(0.015)\end{array}$ & $\begin{array}{c}-0.012 * * * \\
(0.004)\end{array}$ & $\begin{array}{c}-0.016^{* * * *} \\
(0.005)\end{array}$ & $\begin{array}{c}-0.009^{* *} \\
(0.004)\end{array}$ & $\begin{array}{c}-0.008 \\
(0.006)\end{array}$ & $\begin{array}{l}-0.006 \\
(0.009)\end{array}$ & $\begin{array}{c}0.004 \\
(0.016)\end{array}$ \\
\hline Convict Labor (Discrete) & $\begin{array}{c}-0.025 * * * \\
(0.008)\end{array}$ & $\begin{array}{c}-0.018^{* * *} \\
(0.003)\end{array}$ & $\begin{array}{c}-0.041^{* * *} \\
(0.010)\end{array}$ & $\begin{array}{c}-0.014 * * * \\
(0.003)\end{array}$ & $\begin{array}{l}-0.064 \\
(0.044)\end{array}$ & $\begin{array}{l}-0.018 \\
(0.011)\end{array}$ & $\begin{array}{c}-0.004 * * * \\
(0.001)\end{array}$ & $\begin{array}{c}-0.004 * * \\
(0.002)\end{array}$ & $\begin{array}{c}-0.003^{* * *} * \\
(0.001)\end{array}$ & $\begin{array}{c}-0.004^{* *} \\
(0.002)\end{array}$ & $\begin{array}{l}-0.008 \\
(0.005)\end{array}$ & $\begin{array}{l}-0.011 \\
(0.008)\end{array}$ \\
\hline Observations & 1,426 & 1,355 & 1,879 & 1,818 & 1,407 & 1,281 & 1,382 & 1,398 & 1,869 & 1,872 & 1,373 & 1,386 \\
\hline \multirow[t]{2}{*}{ Panel B } & \multicolumn{12}{|c|}{ AS and WH Public Contracts Acts (1936) } \\
\hline & $\mathrm{I}$ & II & III & IV & $\mathrm{V}$ & VI & VII & VIII & IX & $\mathrm{X}$ & $\mathrm{XI}$ & XII \\
\hline Sample & \multicolumn{2}{|c|}{ w/o South } & \multicolumn{2}{|c|}{ w/o West } & \multicolumn{2}{|c|}{ w/o North } & \multicolumn{2}{|c|}{ w/o South } & \multicolumn{2}{|c|}{ w/o West } & \multicolumn{2}{|c|}{ w/o North } \\
\hline \multirow{2}{*}{ Outcome: } & \multicolumn{6}{|c|}{$\Delta$ Wage in Manufacturing } & \multicolumn{6}{|c|}{$\Delta$ Labor-Force Participation } \\
\hline & Female & Male & Female & Male & Female & Male & Female & Male & Female & Male & Female & Male \\
\hline Convict Labor (Continuous) & $\begin{array}{c}0.184 * * * \\
(0.040)\end{array}$ & $\begin{array}{c}0.144 * * * \\
(0.040)\end{array}$ & $\begin{array}{l}0.140^{* *} \\
(0.057)\end{array}$ & $\begin{array}{c}0.141^{* * * *} \\
(0.043)\end{array}$ & $\begin{array}{l}0.101^{* * *} \\
(0.045)\end{array}$ & $\begin{array}{c}0.011 \\
(0.068)\end{array}$ & $\begin{array}{c}0.029^{* * *} \\
(0.006)\end{array}$ & $\begin{array}{c}0.044^{* * * *} \\
(0.012)\end{array}$ & $\begin{array}{l}0.019^{* * *} \\
(0.007)\end{array}$ & $\begin{array}{c}0.028^{* * * *} \\
(0.010)\end{array}$ & $\begin{array}{c}0.015 \\
(0.013)\end{array}$ & $\begin{array}{c}0.027 \\
(0.016)\end{array}$ \\
\hline Convict Labor (Discrete) & $\begin{array}{l}0.021^{*} \\
(0.011)\end{array}$ & $\begin{array}{c}0.023^{* * * *} \\
(0.007)\end{array}$ & $\begin{array}{l}0.030^{* *} \\
(0.012)\end{array}$ & $\begin{array}{l}0.024 * * \\
(0.009)\end{array}$ & $\begin{array}{l}-0.004 \\
(0.044)\end{array}$ & $\begin{array}{l}-0.013 \\
(0.050)\end{array}$ & $\begin{array}{c}0.003 \\
(0.002)\end{array}$ & $\begin{array}{c}0.006^{* * * *} \\
(0.002)\end{array}$ & $\begin{array}{l}0.003^{*} \\
(0.002)\end{array}$ & $\begin{array}{l}0.005^{* *} \\
(0.002)\end{array}$ & $\begin{array}{c}0.003 \\
(0.006)\end{array}$ & $\begin{array}{l}-0.005 \\
(0.011)\end{array}$ \\
\hline Observations & 1,503 & 1,502 & 1,910 & 1,910 & 1,487 & 1,486 & 1,503 & 1,502 & 1,910 & 1,910 & 1,487 & 1,486 \\
\hline
\end{tabular}

Note: Each row contains estimates from a separate regression with continuous and discrete measures of convict labor. I present results for the changes in wages in Columns I to VI. The resulting coefficient is robust to the exclusion of Southern or Western states in Columns I to IV. However, in Panel A, when I exclude Northern states, the estimate becomes insignificant for women but not for men. The coefficient for the continuous specification in Column VI is negative and significant: while its magnitude is smaller than that of the estimate on the full sample, it suggests that there was also a wage effect, although less pronounced, in the South (most of the clothing and shoes there were produced in South Carolina). In Panel B, however, the exclusion of Northern states led to the opposite situation. We see a significant increase in women's wages following the decrease of convict labor in Column V and zero effect in Column VI. This result is in line with the fact that clothing and shoes became dominant industries for prisons. Columns VII to XII suggest that labor-force participation was indeed hindered by convict labor, but it was mostly a Northern thing. Both values of exposure to convict labor are normalized. Coefficients in Panel B are multiplied by -1 to indicate the reduction in convict-labor output. All columns contain OLS in first differences. All columns contain a constant. The following variables are used as controls (in changes): ln of total population, urban share, share of Black and foreign-born population, share of women. Robust, clustered-by-state standard errors are in parentheses. ${ }^{* * *} \mathrm{p}<0.01,{ }^{* *} \mathrm{p}<0.05,{ }^{*} \mathrm{p}<$ 0.1 


\section{C11. Technology Adoption: Evidence from the Firm-Level Data}

In Table C21, I unveil this mechanism using firm-level data from Atack and Bateman (1999). I aggregate firm-level data on the industry-state-decade level to be able to see the effect of convict labor on industries, and I consider the following specification:

$$
y_{i, s, t}=\alpha_{s}+\beta_{t}+\xi_{i}+\gamma C L_{i, s, t}+\Pi X_{i, s, t}+t \delta_{s}+\varepsilon_{i, s, t},
$$

where the unit of observation is the industry $i$ in state $s$ at decade $t$, and $y_{i, s, t}$ is a dependent variable. Because I know the industry in which firm is operating, I use discrete measure of convict labor in industry $i$ in state $s$ at decade $t$ as the treatment. I double-cluster standard errors on the state and industry levels (Cameron, Gelbach and Miller (2011)). ${ }^{76}$

In Columns I to III, I present OLS results of the regression of exposure to convict labor on the share of firms of industry $i$ in state $s$ on the total number of firms in state $s$. Column I reports the specification with industry, state, and decade fixed effects. In Columns II and III, I add industry-year fixed effects and state-specific trends, respectively. A 1\% increase in convict-labor output is associated with $1 \%$ decrease in the share of firms in that industry. In Columns IV to VI the dependent variable is the average capital per firm in industry $i$ in state $s$. A $10 \%$ increase in convict-labor output is associated with (at least) a $\$ 93$ increase in average capital per firm. Meanwhile, I also observe an increase in the capital-labor ratio (Columns VII to IX). These findings suggest that capital labor increased not only because firms in affected industries shifted to better machinery to compete with prison labor but also because more labor-intensive firms died out, thus changing the industrial composition in their states and counties.

TABle C21-Convict labor and technology adoption: Firm-Level data

\begin{tabular}{|c|c|c|c|c|c|c|c|c|c|}
\hline \multirow{3}{*}{$\begin{array}{l}\text { Dependent variable: } \\
\text { Log convict labor, } 1886 \\
\text { (discrete, by state \& SIC2) }\end{array}$} & $\mathrm{I}$ & II & 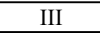 & IV & $\mathrm{V}$ & VI & VII & VIII & IX \\
\hline & \multicolumn{3}{|c|}{ Share of firms in the industry } & \multicolumn{3}{|c|}{ Capital-per-firm } & \multicolumn{3}{|c|}{ Capital-labor ratio $(\mathrm{K} / \mathrm{L})$} \\
\hline & $\begin{array}{l}-0.007 \\
(0.005)\end{array}$ & $\begin{array}{c}-0.009^{*} \\
(0.004)\end{array}$ & $\begin{array}{c}-0.010^{* *} \\
(0.004)\end{array}$ & $\begin{array}{c}719.6^{* *} \\
(334)\end{array}$ & $\begin{array}{c}882.4^{* *} \\
(364)\end{array}$ & $\begin{array}{c}935.5^{* *} \\
(375)\end{array}$ & $\begin{array}{c}138.9^{*} \\
(78)\end{array}$ & $\begin{array}{c}195.2^{*} \\
(111)\end{array}$ & $\begin{array}{r}237.2^{*} \\
(140)\end{array}$ \\
\hline Industry $\mathrm{x}$ year FE & & $\mathrm{X}$ & $\mathrm{X}$ & & $\mathrm{X}$ & $\mathrm{X}$ & & $\mathrm{X}$ & $\mathrm{X}$ \\
\hline State-specific trends & & & $\mathrm{X}$ & & & $\mathrm{X}$ & & & $\mathrm{X}$ \\
\hline R-squared & 0.901 & 0.927 & 0.933 & 0.381 & 0.701 & 0.736 & 0.28 & 0.32 & 0.35 \\
\hline Observations & 293 & 293 & 293 & 293 & 293 & 293 & 293 & 293 & 293 \\
\hline
\end{tabular}

Note: All columns contain constant and log value of manufacturing output. Robust, double-clustered by state and two-digit SIC codes are in parentheses. ${ }^{* * *} \mathrm{p}<0.01,{ }^{* *} \mathrm{p}<0.05,{ }^{*} \mathrm{p}<0.1$

\footnotetext{
${ }^{76}$ Clustering by industry or state yields similar or smaller standard errors, which I do not report.
} 


\section{Estimating the Technological Frontier}

To estimate technological-choice shifts, I use the methodology developed in Caselli and Coleman (2006). I start by assuming the CES production function:

$$
Y=\left(\left(A_{k} K\right)^{\alpha \sigma}+\left(A_{L} L\right)^{(1-\alpha) \sigma}\right)^{\frac{1}{\sigma}} .
$$

To compute productivity of capital $\left(A_{K}\right)$ and productivity of labor $\left(A_{L}\right)$, I use county-industry-level data from Hornbeck and Rotemberg (2018).

First, I create a "treated" indicator variable that is equal to one if county $c$, industry $i$ is in the top third percentile of the competition with prison-made goods in 1886. I also created a "not treated" variable that is equal to one if county $c$, industry $i$ is in the bottom third percentile of the competition with prison-made goods in 1886. I drop firms located in the middle third. ${ }^{77}$

Second, I sum up output, capital, labor, and total wages over counties, treatment variable, and decade (1870 and 1880, before and after convict labor was introduced). I compute wages $w$ as a ratio of total wages $(w L)$ divided by total the number of laborers $(L)$. As I do not have the price of capital $(r)$, I compute it from the budget constraint $\left(r=\frac{Y-w L}{K}\right)$.

Then I can compute capital and labor productivity:

$$
A_{K}=\frac{Y}{K}\left(\frac{r K}{r K+w L}\right)^{\frac{1}{\sigma}}, \text { and } A_{L}=\frac{Y}{L}\left(\frac{w L}{r K+w L}\right)^{\frac{1}{\sigma}} .
$$

The main idea of Caselli and Coleman (2006) is that countries can specialize in adopting technologies favoring labor while making capital less productive, or adopting technologies favoring capital but making labor less productive. ${ }^{78}$ Thus the "technological frontier" can be interpreted as a budget constraint for two types of technologies. By investing in technology supporting in capital, a firm invests less in those helping labor. And being on the frontier means that a firm maximizes its budget. I measure the technological frontier for industries in treated counties before and after convict labor was allowed. Industries in counties not affected by the competition are used as a placebo to show that they do not exhibit any similar changes.

Thus the technological frontier can be written as follows:

$$
\begin{array}{cl} 
& Y=\left(\left(A_{K} K\right)^{\alpha \sigma}+\left(A_{L} L\right)^{(1-\alpha) \sigma}\right)^{\frac{1}{\sigma}} \\
\text { s.t. } & \left(A_{K}\right)^{\omega}+\gamma\left(A_{L}\right)^{\omega} \leq B, \text { where } \omega, \gamma, B>0 .
\end{array}
$$

I also assume that $\omega>\sigma /(1-\sigma)$. Following Caselli and Coleman (2006), I use $\sigma=0.09$. Results are robust to other values of $\sigma$ that Caselli and Coleman (2006) use for robustness.

\footnotetext{
${ }^{77} \mathrm{I}$ also tried to split counties by 50 th and 25 th percentiles and the results hold.

${ }^{78}$ The authors use high-skilled labor vs. low-skilled labor technologies in their model, but the idea is the same.
} 
This system of equation can be solved and shown as a function of the technological frontier $(B)$ :

$$
\begin{aligned}
& A_{K}=\left(\frac{B}{1+\gamma^{\sigma /(\sigma-\omega)}(K / L)^{\omega \sigma /(\sigma-\omega)}}\right)^{\frac{1}{\omega}}, \\
& A_{L}=\left(\frac{B / \gamma}{1+\gamma^{\sigma /(\omega-\sigma)}(K / L)^{\omega \sigma /(\omega-\sigma)}}\right)^{\frac{1}{\omega}} .
\end{aligned}
$$

However, parameters $\omega$ and $\gamma$ are unknown and needed to be estimated. To do so, I first derive both first-order conditions and divide one on another to get the following equation:

$$
\ln \left(\frac{A_{K}^{i}}{A_{L}^{i}}\right)=\frac{\sigma}{\omega-\sigma} \ln \left(\frac{K^{i}}{L^{i}}\right)+\frac{1}{\omega-\sigma} \ln (\gamma) .
$$

Assuming, that $\gamma$ differs for all observations, we can estimate $\omega$ and $\gamma$ from the regression:

$$
\ln \left(\frac{A_{K}^{i}}{A_{L}^{i}}\right)=\underbrace{\frac{\sigma}{\omega-\sigma}}_{\tau} \ln \left(\frac{K^{i}}{L^{i}}\right)+\underbrace{\frac{1}{\omega-\sigma} \ln \left(\gamma^{i}\right)}_{\nu^{i}} .
$$

As I have already estimated the productivity, we know that $\ln \left(\frac{A_{K}^{i}}{A_{L}^{i}}\right) ; \ln \left(\frac{K^{i}}{L^{i}}\right)$ is also known. I estimate OLS to get coefficient $\widehat{\tau}$ and residual $\widehat{\nu^{i}}$. Then I get $\omega$ and $\gamma^{i}$ by solving the following system of equations:

$$
\begin{gathered}
\frac{\sigma}{\omega-\sigma}=\widehat{\tau}, \\
\frac{1}{\omega-\sigma} \ln \left(\gamma^{i}\right)=\widehat{\nu^{i}} .
\end{gathered}
$$

Finally, I plot the log of productivity of capital and labor for treated and untreated counties in 1870 and 1880 to demonstrate that firms in affected counties and industries invest in more capital-intensive technologies. 

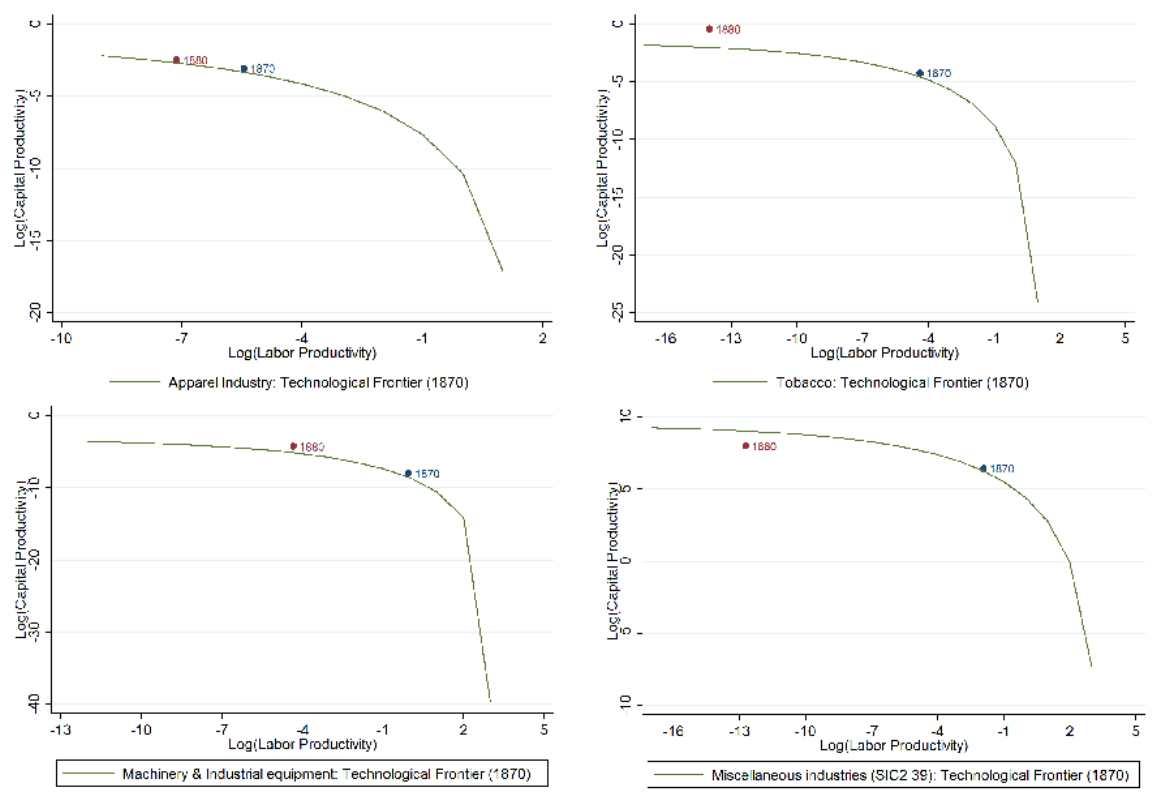

Figure D1. TeChnological Frontier in Other SElected industries

The Effect of Convict Labor on Wages and Firms:

Panel Specification (1850-1950)

In the previous sections, I studied the effects of the convict-labor system in the United States. Using it as a nationwide movement uncorrelated with local economic conditions and addressing endogeneity concerns with an IV strategy based on the pre-convict-labor-era prison capacities I showed that competition with prison-made goods adversely affected wages in manufacturing and manufacturing employment while also leading to increased patenting in the affected industries. In this section, I study the effect of convict labor from 1850 to 1950 using cross-sectional and temporal variation in convict labor.

\section{E1. Background: Rise and Fall of Historical Convict Labor}

\section{Types of Convict-Labor Systems in the United States}

U.S. convict-labor systems have seen many changes over the past 150 years. The development of the penitentiary was integrally related to rapid industrialization, and convict labor became widespread only after the Civil War (Wilson (1933)). At first, hard labor was seen as more humane and efficient than physical punishment (a belief influenced by Quakers and Protestants), but over time convict labor also became a major source of income for state governments. 
After the Civil War, states started to enact convict-labor laws that allowed prisoners to be employed in productive labor. Legislation varied a lot regarding both profitability for the state and other parties involved, and the working conditions of prisoners. There were six systems of convict labor: "contract," "piece-price," "state-account," "state-use," "public works and ways," and "convict leasing."

The "private" systems:

- Under the contract system, prison officers, under legal instruction, advertised for bids for the employment of the convicts of their respective institutions. The highest responsible bidder would secure the contract. The contractor employed a certain number of convicts at a certain price per day. The prison or the state furnished power, and sometimes machinery, but rarely tools. All convicts were employed within the walls of the prison.

- The piece-price system was similar to the contract system, except that the contractor had nothing to do with the convicts. The contractor furnished the prison officers with material ready for manufacturing, and the prison officers agreed to return the completed work, for which the government received an agreed price per piece. Under this system, the contractor had no position at the prison.

- Under the convict leasing system, prisons and local sheriffs had the right to "lease" convicts to private individuals, firms, or farms and plantations. The lessee paid the prison and various public officials involved and was responsible for feeding, clothing, and housing the prisoners (Sellin (1976)). ${ }^{79}$

The "public" systems:

- Under the state-account system, the prison acted as a firm and sold goods on the market, thus assuming all business risks. All profit went directly to the states. However, this system had two major problems. The first problem was managerial: wardens were often bad businessmen. Second, prisons needed to employ convicts even if there was no demand for the goods produced.

- The state-use system is similar to the state-account system, except that the sale of goods was limited exclusively to state departments and agencies.

- Under the public works and ways (PWW) system, as is evident from the name, prisoners constructed and repaired roads rather than producing goods for consumption. ${ }^{80}$

\footnotetext{
${ }^{79}$ Convict leasing was the most profitable system of convict labor (Department of Labor $(1887,1914)$ ) for the states.

${ }^{80}$ The PWW system shares similarities with the convict leasing system, namely that prisoners did not occupy prisons' capacities. However, as they were working on public projects, states were not entirely free from housing and guarding duties.
} 
Contract, piece-price, and convict leasing systems were sufficiently similar, and I will refer to them as private systems. They assumed private operation of convict labor and were producing goods sold on the open market (often interstate), thus competing with free labor. ${ }^{81}$ This proved disruptive for two reasons. First, convict labor was significantly cheaper than free labor. Second, firms that took advantage of the contract system were criticized for undercutting their prices below the market price of their goods. ${ }^{82}$

The state-account system produced goods for open sale and thus competed with goods produced by free labor. Put simply, the prison was a firm, and its warden a manager. Prisons that operated under this system were less efficient than the private systems: they often had to produce goods for which the state provided machinery but not the goods that were most profitable. Moreover, wardens were often bad entrepreneurs (Hiller (1915); Gildemeister (1978)). At the same time, the state-use and PWW systems intended to produce goods (construction services in case of the PWW) that would be consumed by its state agencies. The Department of Labor (1914) considered them less dangerous for free labor regarding competition. As convict labor under these systems was entirely under the prison's supervision, I refer to them as public systems.
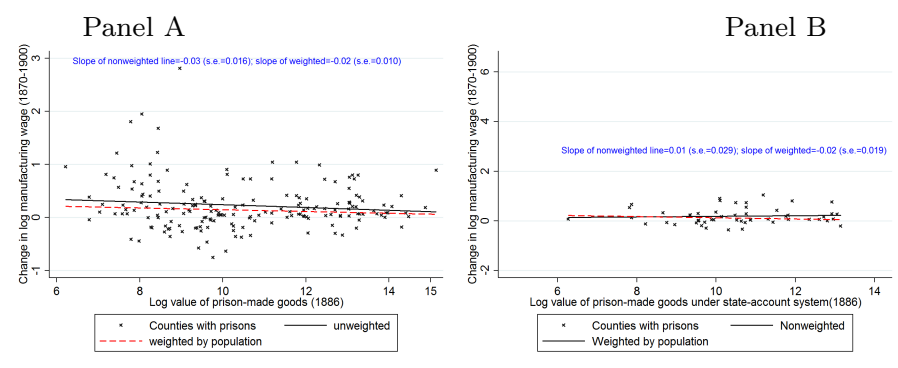

Figure E1. Convict labor and Changes in manufacturing Wages, By system of CONVict Labor

Note: Each cross is a county.

In Panel A of Figure E1, I plot changes in log manufacturing wages between 1870 and 1900 on the horizontal axis, and the log value of prison-made goods in 1886 on the vertical axis. We can see a negative slope (approximately -0.03 $($ s.e. $=0.016))$. It suggests that counties in which prisons produced more prisonmade goods experienced lower wage growth. In Panel B, I use the value of goods produced only under the public systems on the horizontal axis instead. The slope is statistically not different from zero. It suggests that public systems were less

\footnotetext{
${ }^{81}$ The labor cost of prison-made goods was fixed for convict leasing and contract systems since the contractor/lessee paid the prison a lump-sum payment only. Under the piece-price system, labor costs were variable.

${ }^{82}$ All states used convict labor, and all but five states (Colorado, Idaho, Montana, North Dakota, and Utah) involved private contractors.
} 
harmful (if harmful at all) to free labor.

\section{Evolution of Historical Convict Labor}

Table E1 shows that private systems experienced a tremendous growth after 1870 , both in shares and in the number of employed prisoners. ${ }^{83}$ Private forms of convict labor were initially more popular than public ones. ${ }^{84}$ But they were gradually replaced with allegedly less harmful public systems due to increasing social pressure (Department of Labor (1914); Sharkey and Patterson (1933)). ${ }^{85}$ However, the struggle against convict labor continued despite the shift from private to public forms.

Table E1-Evolution of Convict labor: Share of employed Convicts

\begin{tabular}{|c|c|c|c|c|c|c|c|c|}
\hline System & $1870^{*}$ & 1886 & 1895 & 1905 & 1914 & 1923 & 1932 & 1940 \\
\hline Convict Leasing & 1 & 20 & 14 & 6 & 3 & 0 & 0 & 0 \\
\hline Contract & 6 & 30 & 24 & 23 & 16 & 7 & 3 & 0 \\
\hline Piece-Price & 0 & 6 & 10 & 5 & 4 & 4 & 6 & 0 \\
\hline State-Account & & & & 14 & 20 & 16 & 10 & 5 \\
\hline State-Use & 5\{ & 20\{ & 24\{ & 12 & 14 & 22 & 22 & 26 \\
\hline Public Works and Ways & 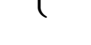 & 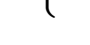 & 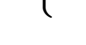 & 5 & 7 & 12 & 12 & 13 \\
\hline Not Employed & 87 & 24 & 28 & 35 & 36 & 39 & 47 & 56 \\
\hline & 100 & 100 & 100 & 100 & 100 & 100 & 100 & 100 \\
\hline
\end{tabular}

Note: State-account, state-use, and public works and ways systems were reported together as the publicaccount system before 1905. Source: U.S. Department of Labor. * Shares for 1870 are the upper bounds, as there are no data on how many inmates actually worked, only the total prison population of the prisons that employed prisoners.

States could only pass legislation regulating production of convict-made goods in their state; they could not regulate interstate trade. And since approximately $60 \%$ (Sharkey and Patterson (1933)) of all prison-made goods were sold outside their state of origin, firms using free labor opposed convict labor anywhere in the country. Hence, Congress had attempted to enact laws prohibiting the use of prison labor since the beginning of the 1900s; however, the first anti-penal labor law (Hawes-Cooper Convict Labor Act) wasn't signed until 1929 and enacted until 1934. That act allowed states to prohibit sales of convict-made goods produced in other states. Two years later, in 1936, two more federal laws (the AshurstSumners and Walsh-Healey Public Contracts Acts, 1936) were enacted to prohibit

\footnotetext{
${ }^{83}$ Most convicts in New York were employed under the contract system, and few were leased out in the Southern states.

${ }^{84}$ Similar trends can be observed for the value of goods produced under each system of convict labor in Table G1.

${ }^{85}$ According to the Department of Labor (1925), convict leasing, which existed mostly in the Southern states, had dissipated by 1923. However, convicts were redirected to work under PWW system (by constructing highways and railroads) or to harvest cotton on penal state farms under the state-use system (Shichor (1995)).
} 
any interstate trade with prison-made goods and to prohibit prisons from signing any contracts with private contractors. ${ }^{86}$ As a result, by 1940, all convict labor was concentrated in the public systems, either producing goods for consumption by its own state or employing prisoners in chain gangs. The latter was abolished in 1941 by President Roosevelt's Circular 3591. The state-use system of convict labor remained the only form of convict labor afterward, and the problem of competition with convict labor was quieted until 1979, when Congress revived the private system of convict labor by establishing the Prison Industry Enhancement Certification Program.

\section{E2. Convict Labor and Local Labor-Market Outcomes}

Table E1 identifies the rise and fall of the six systems, particularly the massive unexpected expansion of private forms of convict labor from 1870 to 1886. In this section, I exploit time-variation in convict-labor legislation, as new states continued to switch toward private systems after 1886, and there was a gradual decreasing (increasing) trend in the prevalence of private (public) forms of convict labor.

I start my analysis with the OLS regression of wages on convict labor output:

$$
y_{c, t}=\alpha_{c}+\beta_{t}+\gamma C L_{c, t}+\Psi X_{c, t}+t \delta_{c}+\varepsilon_{c, t} .
$$

The dependent variable $y_{c, t}$ is the dependent variable (e.g., log of the average annual wage (real) in manufacturing) in county $c$ at decade $t, t \in(1860,1940)$. Variable $C L_{c, t}$ is the exposure of county $c$ at decade $t$ to convict labor; $X_{c, t}$ is a matrix of county-level controls; $\alpha_{c}$, and $\beta_{t}$ are county and decade fixed effects; and $t \delta_{c}$ are county-specific time trends. I use the same set of controls (but in levels) as in the crossectional specification. I also control for the cubic polynomial of latitude and longitude interacted with decade dummies to address westward growth. Here, I use population weights. ${ }^{87}$ Standard errors are clustered errors on the state level.

I use the same continuous and discrete measures of exposure to convict labor as in the previous section. Both measures are equal to zero for $t=1850,1860,1870,1950$ and equal to nonzero for other decades:

$$
C L_{c, t}^{\text {cont. }}=\sum_{i \in I}\left(\lambda_{i, c} \times \sum_{p \in P_{t}} \frac{\ln \left(\text { Value of goods produced in prisons }_{i, p, t}\right)}{\text { Distance }_{c, p}}\right)
$$

\footnotetext{
${ }^{86}$ However, contracts not exceeding $\$ 10,000$ annually were still permitted.

${ }^{87}$ All results hold if I use weighting by market access, or do not weight at all.
} 
$C L_{c, t}^{\text {disc. }}=\sum_{i \in I}\left(\lambda_{i, c} \times \ln \left(\sum_{p \in P_{c, t}}\left(\right.\right.\right.$ Value of goods produced in prisons $\left.\left.\left.{ }_{i, p, t}\right)\right)\right)$,

where $P_{t}$ is a set of prisons that existed in year $t, P_{c, t}$ is a set of prisons that existed in county $c$ in year $t$, and Distance ${ }_{c, p}$ is the distance (in $\mathrm{km}$ ) from prison $p$ to county $c$ 's centroid. Here I use distance-to-prison instead of the trade costs between counties, as it is not available for all decades. Also, my results hold if I use actual trade costs from 1870 to 1920 , trade costs of 1870 for decades before 1870, and trade costs of 1920 for decades after 1920.

The two-way fixed-effect approach fails if I have an omitted variable whose differential trend is correlated with the differential trend in the dependent and explanatory variables. Thus, this model has the same endogeneity concerns as the cross-section of first differences. The main difference of this model is that I use more variation in dependent and explanatory variables, and that I allow each county to be on its own specific time trends. It also helps to control for the fact that some states chose to close some prisons and open new ones, and to control for changing state-level legislation on prisons and convict labor. ${ }^{88}$

The model also helps with the scaling measurement error concern related to under-reporting: as county fixed effects and state linear trends allow this concern to be valid if there are differential trends in under-reporting.

Here, I also use IV estimation. The panel nature allows me to use the interaction of two different sources of plausibly exogenous variation. First, cross-sectional variation comes from the state prisons that existed before the years when convict labor was allowed in corresponding states. Second, as a source of time variation, I use the timing of the adoption of private systems that instituted the use of convict labor for manufacturing goods on the open market. In particular, I use the fact that after 1870 there was a differential change in the amount of prisonmade goods: from a near-zero-dollar amount, mostly stone production, to $4.2 \%$ of total manufacturing output. Private systems enabled prisons to buy machinery and provided foremen who organized prisons into firms. At the same time, the replacement of private systems with public ones followed the enactment of local anti-convict-labor legislation, whose aim was to make convict labor less effective and less destructive to free labor, which led to worse managerial practices and less control of inmates. Moreover, prisons were operated by their wardens; all contracts and decisions about the employment of prisoners were made at the prison level, and the timing of state-level laws was plausibly exogenous.

To conclude, I assume that the interaction of preexisting prisons and the timing of adoption of private systems is uncorrelated with the error term, is good

\footnotetext{
${ }^{88}$ For example, changing systems of convict-labor laws requiring all prison output to be labeled "Made in Prison," or other state-specific legislation (e.g., prohibiting prisoners from working as hatters in New Jersey or prohibiting prisons in Massachusetts from buying new machinery).
} 
predictors of the usage of convict labor, and does not directly affect wages in manufacturing.

The first stage of the 2SLS specification can be written as:

$$
C L_{c, t}=\tilde{\alpha}_{c}+\tilde{\beta}_{t}+\tilde{\gamma} O P_{c, t}+\tilde{\Psi} X_{c, t}+t \tilde{\delta}_{c}+\epsilon_{c, t} .
$$

The second stage can be written as:

$$
y_{c, t}=\alpha_{c}+\beta_{t}+\gamma \widehat{C L}_{c, t}+\Psi X_{c, t}+t \delta_{c}+\varepsilon_{c, t},
$$

where the variable $O P_{c, t}$ measures exposure of each county by the old prisons around it: $O P_{c, t}=\sum_{p \in P}\left(\frac{\ln \left(\text { Old prison capacity }_{p}\right)}{\text { Distance }_{c, p}}\right) \cdot D(\text { private system }=1)_{s, t}$, and $D$ (private system $=1)_{s, t}$ is an indicator function that is equal to one if state $s$ that contained prison $p$ had already adopted a private system at decade $t$, and zero if state $s$ did not or had already completely switched to public systems.

The results are shown in Table E2. The first four columns contain results for the full sample of states, while the last six contain results for the subsamples of states. For the full sample, in Columns I and III, I present an OLS regression, and I show second-stage results of the IV specification in Columns II and IV. 2SLS Columns also include the first-stage coefficient of the instrument on the explanatory variable. For the subsamples, I provide only second-stage results.

\begin{tabular}{|c|c|c|c|c|c|c|c|c|c|c|}
\hline \multirow{4}{*}{ Sample } & 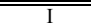 & "II & "IIII & $\overline{\mathrm{IIV}}$ & 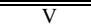 & "VI & 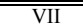 & VIII & IIX & 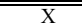 \\
\hline & \multicolumn{10}{|c|}{ Dependent Variable: $\ln$ of Wage in Manufacturing } \\
\hline & \multicolumn{4}{|c|}{ Full Sample } & \multicolumn{2}{|c|}{ w/o South } & \multicolumn{2}{|c|}{ w/o West } & \multicolumn{2}{|c|}{ w/o North } \\
\hline & OLS & $2 \mathrm{SLS}$ & OLS & 2SLS & 2SLS & 2SLS & 2SLS & 2SLS & 2SLS & 2SLS \\
\hline Convict Labor (Continuous) & $\begin{array}{c}-0.07 * * * \\
(0.012)\end{array}$ & $\begin{array}{c}-0.20^{* * *} * \\
(0.039)\end{array}$ & & & $\begin{array}{c}-0.18^{* * *} \\
(0.043)\end{array}$ & & $\begin{array}{c}-0.18^{* * * *} \\
(0.043)\end{array}$ & & $\begin{array}{c}-0.04 * * * \\
(0.012)\end{array}$ & \\
\hline Convict Labor (Discrete) & & & $\begin{array}{c}-0.02 * * * \\
(0.005)\end{array}$ & $\begin{array}{c}-0.24 * * * \\
(0.080)\end{array}$ & & $\begin{array}{c}-0.18^{* * *} \\
(0.069)\end{array}$ & & $\begin{array}{c}-0.12^{* * *} \\
(0.021)\end{array}$ & & $\begin{array}{r}-0.07^{* * *} \\
(0.017)\end{array}$ \\
\hline R-squared & 0.878 & 0.826 & 0.873 & 0.670 & 0.844 & 0.709 & 0.79 & 0.75 & 0.80 & 0.80 \\
\hline Kleibergen-Paap F-stat & & 14.90 & & 7.162 & 11.42 & 6.055 & 11.42 & 20.6 & 105.8 & 41.9 \\
\hline Instrument's coefficient & & $\begin{array}{c}0.38 * * * \\
(0.086)\end{array}$ & & $\begin{array}{c}0.55 * * * \\
(0.155)\end{array}$ & $\begin{array}{c}0.38 * * * \\
(0.101)\end{array}$ & $\begin{array}{c}0.62 * * * \\
(0.171)\end{array}$ & $\begin{array}{c}0.24 * * * \\
(0.054)\end{array}$ & $\begin{array}{c}1.03^{* * *} \\
(0.148)\end{array}$ & $\begin{array}{c}0.36^{* * *} \\
(0.080)\end{array}$ & $\begin{array}{r}0.26^{* * * *} \\
(0.085)\end{array}$ \\
\hline \# States & & & & & & & & & & 2 \\
\hline Observations & 15,366 & 15,364 & 15,366 & 15,364 & 8,685 & 8,685 & 8,685 & 13,314 & 8,963 & 8,963 \\
\hline
\end{tabular}

TABle E2 - Convict labor and Wages: Panel Specification

Note: Both values of exposure to convict labor are normalized. All columns contain constant, county, and decade fixed effects. The following variables are used as controls: ln of total population, urban share, share of Black population, share of women, share of foreign-born population, ln of manufacturing output, employment share in manufacturing, employment share in agriculture, ln of value of farm products, number of dwellings, and county-specific linear trends. Columns with second-stage include the first-stage coefficient of instrument on the explanatory variable. Robust, clustered-by-state standard errors are in parentheses. $* * * \mathrm{p}<0.01, * * \mathrm{p}<0.05, * \mathrm{p}<0.1$

The OLS point-estimate of wage elasticity in Column I is negative and signifi- 
cant. So is the IV coefficient in Column II. One standard deviation in exposure to prison-made goods decreases wages by $20 \%{ }^{89}$ The difference between the countylevel convict labor change in counties at the 25 th and 75 th percentiles was a 0.63 standard deviation. Evaluated using the Column II estimate, a county at the 25th percentile experienced an $12.6 \%$ larger manufacturing wage decrease (or a $2 \%$ larger decline in mean log annual wages in manufacturing) than a county at the 75th percentile. The direction of IV bias supports the selection concerns raised above: prisons were built in areas where wage increased faster, and that the measurement error bias is present. The estimated effect may be smaller than the true effect since I use average wages in manufacturing, which include wages of white-collar workers and high-skilled laborers.

In Columns III and IV, I use the discrete measure of exposure to convict labor. This specification also alleviates the concern that distances to prisons correlate with manufacturing outcomes. ${ }^{90}$ The OLS coefficient becomes smaller while significant, but the second-stage coefficient increases slightly in magnitude. One standard deviation in exposure to prison-made goods decreases wages by $24 \%$. The most plausible explanation for this effect is that the effect of competition with prison-made goods exceeded the boundary of a county, and thus in the discrete specification, I count partially treated counties (close to counties with prisons) as control counties. Thus the differences in wages between them is smaller, and I underestimate the effect of convict labor.

Regressions on the subsamples help us to identify where the effects on wages derive from. ${ }^{91}$ In Columns V and VI of Table E2, I drop the Southern states; the resulting second-stage coefficients are not statistically different from those in the full sample, while standard errors increase slightly. In Columns VII and VIII, where I omit the Western states, coefficients increase slightly in magnitude. Finally, in Columns IX and X, I omit the Northern states; the negative effect of wages remains significant, but the magnitude of the effect become much smaller. It suggests that convict labor affected wages in manufacturing mostly in the Northern states. The following explanation could support this finding. Most convicts in the Southern and Western states were employed in farming, timber production, mining/quarrying, or road construction. None of these sectors counts as manufacturing, thus my explanatory variable excludes them by construction. Border Southern states, however, could still have been affected by the goods produced by nearby Northern prisons.

In Table E3, I do not find evidence that convict labor caused unemployment and decreased the labor-force participation rate in the panel specification. One plau-

\footnotetext{
${ }^{89}$ The first-stage F-statistics is 18 , and the Anderson-Rubin test is rejected, suggesting that the instrument is strong. Partial $R^{2}$ is equal to 0.06 , indicating that the first-stage power is driven by the instrument, rather than the variety of fixed effects, trends, and controls.

${ }^{90}$ It also helps if spatial patterns in adoption of convict labor laws bias my results (Dube, Lester and Reich (2016)).

${ }^{91}$ I use U.S. Census Bureau definitions of the U.S. regions. Western states include Great Plains and the Far West. Northern states include the Midwest and Northeast.
} 
TABle E3-COnvict Labor And other Employment outcomes: Panel SPECification

\begin{tabular}{|c|c|c|c|c|c|c|c|c|c|c|}
\hline & $\overline{I I}$ & $\overline{\text { III }}$ & $\overline{\text { III }}$ & $\overline{\mathrm{IV}}$ & $\overline{\mathrm{V}}$ & $\overline{\mathrm{VI}}$ & VII & "VIII & $\overline{\text { IX }}$ & $\overline{\mathrm{X}}$ \\
\hline & \multicolumn{10}{|c|}{ Dependent Variable: Labor-Force Participation } \\
\hline \multirow[t]{2}{*}{ Sample } & \multicolumn{4}{|c|}{ Full Sample } & \multicolumn{2}{|c|}{ w/o South } & \multicolumn{2}{|c|}{ w/o West } & \multicolumn{2}{|c|}{ w/o North } \\
\hline & OLS & 2SLS & OLS & 2SLS & 2SLS & 2SLS & 2SLS & 2SLS & 2SLS & 2SLS \\
\hline Convict Labor (Continuous) & $\begin{array}{c}0.01 \\
(0.007)\end{array}$ & $\begin{array}{c}-0.03 \\
(0.021)\end{array}$ & & & $\begin{array}{c}-0.00 \\
(0.016)\end{array}$ & & $\begin{array}{c}-0.04 \\
(0.024)\end{array}$ & & $\begin{array}{c}-0.01 \\
(0.028)\end{array}$ & \\
\hline Convict Labor (Discrete) & & & $\begin{array}{c}-0.00^{*} \\
(0.001)\end{array}$ & $\begin{array}{l}-0.02 * \\
(0.011)\end{array}$ & & $\begin{array}{c}-0.00 \\
(0.007)\end{array}$ & & $\begin{array}{l}-0.02^{*} \\
(0.011)\end{array}$ & & $\begin{array}{c}-0.04 \\
(0.044)\end{array}$ \\
\hline R-squared & 0.59 & 0.37 & 0.61 & 0.38 & 0.36 & 0.38 & 0.37 & 0.38 & 0.42 & 0.44 \\
\hline Kleibergen-Paap F-stat & & 13.67 & & 5.72 & 15.30 & 41.20 & 12.22 & 5.28 & 4.36 & 1.822 \\
\hline Instrument's coefficient & & $\begin{array}{c}0.25^{* * *} \\
(0.074)\end{array}$ & & $\begin{array}{l}0.43^{* *} \\
(0.197)\end{array}$ & $\begin{array}{c}0.32 * * * \\
(0.088)\end{array}$ & $\begin{array}{c}0.72 * * * \\
(0.122)\end{array}$ & $\begin{array}{c}0.25 * * * \\
(0.078)\end{array}$ & $\begin{array}{l}0.44^{* *} \\
(0.203)\end{array}$ & $\begin{array}{l}0.23 * * \\
(0.098)\end{array}$ & $\begin{array}{c}0.12 \\
(0.158)\end{array}$ \\
\hline \# States & \multicolumn{4}{|c|}{41} & \multicolumn{2}{|c|}{29} & \multicolumn{2}{|c|}{30} & \multicolumn{2}{|c|}{22} \\
\hline \multirow[t]{3}{*}{ Observations } & 15,612 & 15,612 & 13,470 & 13,470 & 8,488 & 7,286 & 14,794 & 12,946 & 9,220 & 7,701 \\
\hline & I & II & III & IV & $\mathrm{V}$ & VI & VII & VIII & IX & $\mathrm{X}$ \\
\hline & \multicolumn{10}{|c|}{ Dependent Variable: Employment Share in Manufacturing } \\
\hline \multirow{2}{*}{ Sample } & \multicolumn{4}{|c|}{ Full Sample } & \multicolumn{2}{|c|}{ w/o South } & \multicolumn{2}{|c|}{ w/o West } & \multicolumn{2}{|c|}{ w/o North } \\
\hline & OLS & 2SLS & OLS & 2SLS & 2SLS & 2SLS & 2SLS & 2SLS & 2SLS & 2SLS \\
\hline Convict Labor (Continuous) & $\begin{array}{c}0.00 \\
(0.003)\end{array}$ & $\begin{array}{c}-0.00 \\
(0.007)\end{array}$ & & & $\begin{array}{c}-0.01 \\
(0.008)\end{array}$ & & $\begin{array}{c}-0.00 \\
(0.000)\end{array}$ & & $\begin{array}{c}0.00 \\
(0.004)\end{array}$ & \\
\hline Convict Labor (Discrete) & & & $\begin{array}{c}-0.00 \\
(0.002)\end{array}$ & $\begin{array}{c}-0.00 \\
(0.009)\end{array}$ & & $\begin{array}{c}-0.01 \\
(0.011)\end{array}$ & & $\begin{array}{c}-0.01 \\
(0.009)\end{array}$ & & $\begin{array}{c}0.01 \\
(0.013)\end{array}$ \\
\hline R-squared & 0.838 & 0.747 & 0.838 & 0.747 & 0.806 & 0.799 & 1.000 & 0.758 & 0.595 & 0.595 \\
\hline Kleibergen-Paap F-stat & & 27.12 & & 7.121 & 22.93 & 5.974 & 25.51 & 6.904 & 40.75 & 13.58 \\
\hline Instrument's coefficient & & $\begin{array}{c}0.49^{* * *} \\
(0.099)\end{array}$ & & $\begin{array}{l}0.35^{* *} \\
(0.137)\end{array}$ & $\begin{array}{c}0.46^{* * *} \\
(0.100)\end{array}$ & $\begin{array}{l}0.37^{* *} \\
(0.160)\end{array}$ & $\begin{array}{c}0.49^{* * *} * \\
(0.102)\end{array}$ & $\begin{array}{l}0.36^{* *} \\
(0.142)\end{array}$ & $\begin{array}{c}0.66^{* * *} \\
(0.108)\end{array}$ & $\begin{array}{c}0.21 * * * \\
(0.060)\end{array}$ \\
\hline \# States & & & & & & & & & & \\
\hline Observations & 19,293 & 19,293 & 19,293 & 19,293 & 10,788 & 10,788 & 16,444 & 16,444 & 11,354 & 11,354 \\
\hline
\end{tabular}

Note: Both values of exposure to convict labor are normalized. All columns contain constant, county, and decade fixed effects. The following variables are used as controls: ln of total population, urban share, share of Black population, share of women, share of foreign-born population, ln of manufacturing output, ln of value of farm products, number of dwellings, number of slaves, and county-specific linear trends. Columns with second-stage results include the first-stage coefficient of instrument on the explanatory variable. Robust, clustered-by-state standard errors are in parentheses. $* * * \mathrm{p}<0.01, * * \mathrm{p}<0.05, * \mathrm{p}$ $<0.1$

sible explanation is that convict labor may have affected labor-force participation only at the time it was introduced (and abolished).

\section{Convict Labor and Firms: Panel Specification (1850-1950)}

I use the same specification to estimate the effect of convict labor on patenting and technology adoption. The results are shown in Table F1. The first four columns contain results for the full sample of states, while the last six columns contain results for the subsamples of states. Columns I and III present the OLS regression; I show second-stage results of the IV specification in Columns II and IV. Columns with second-stage results include the first-stage coefficient of the instrument on the explanatory variable. For the subsamples, I provide only results of the second stages.

In Panel A, I report the results for the county-level number of patents registered in the next decade. Counties more exposed to prisons had more patents registered. The difference between the county-level convict-labor change in counties at the 25 th and 75 th percentiles was a 0.6 standard deviation. Using the estimate from 
Column II, the more exposed county would be expected to experience a 0.8 standard-deviation larger number of registered patents per 10,000 people. The results of the discrete measure yield similar results, though the magnitude of the coefficient drops. Table F2 shows absence of the effect of convict labor on patents in noncompeting industries.

Table F1-Convict labor and technology adoption: Panel SPecification

\begin{tabular}{|c|c|c|c|c|c|c|c|c|c|c|}
\hline \multirow[t]{2}{*}{ 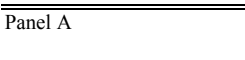 } & $\overline{\mathrm{II}}$ & $\overline{\text { III }}$ & 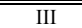 & 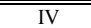 & 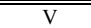 & 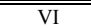 & 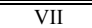 & " VIII & 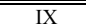 & $\overline{\mathrm{X}}$ \\
\hline & \multicolumn{10}{|c|}{ Dependent Variable: Number of Patents in Competing Industries per 10,000 people } \\
\hline \multirow[t]{2}{*}{ Sample } & \multicolumn{4}{|c|}{ Full Sample } & \multicolumn{2}{|c|}{ w/o South } & \multicolumn{2}{|c|}{ w/o West } & \multicolumn{2}{|c|}{ w/o North } \\
\hline & OLS & 2SLS & OLS & 2SLS & 2SLS & 2SLS & 2SLS & 2SLS & 2SLS & 2SLS \\
\hline \multirow[t]{2}{*}{ Convict Labor (Continuous) } & $0.01^{* * *}$ & $0.03^{* *}$ & & & $0.03^{* * *}$ & & $0.03^{* *}$ & & 0.00 & \\
\hline & $(0.002)$ & $(0.012)$ & & & $(0.011)$ & & $(0.012)$ & & $(0.000)$ & \\
\hline Convict Labor (Discrete) & & & $\begin{array}{c}0.00^{* * *} \\
(0.001)\end{array}$ & $\begin{array}{l}0.02 * * \\
(0.007)\end{array}$ & & $\begin{array}{c}0.02 * * * \\
(0.006)\end{array}$ & & $\begin{array}{l}0.02 * * \\
(0.007)\end{array}$ & & $\begin{array}{c}0.00 \\
(0.000)\end{array}$ \\
\hline R-squared & 0.991 & 0.953 & 0.991 & 0.939 & 0.961 & 0.948 & 0.955 & 0.942 & 0.983 & 0.983 \\
\hline Kleibergen-Paap F-stat & & 16.52 & & 13.87 & 13.91 & 11.41 & 15.53 & 13.29 & 40.11 & 25.10 \\
\hline Instrument's coefficient & & $\begin{array}{c}0.46^{* * *} \\
(0.114)\end{array}$ & & $\begin{array}{l}0.36^{* *} \\
(0.144)\end{array}$ & $\begin{array}{c}0.43 * * * \\
(0.121)\end{array}$ & $\begin{array}{l}0.39 * * \\
(0.167)\end{array}$ & $\begin{array}{c}0.45^{* * *} \\
(0.117)\end{array}$ & $\begin{array}{l}0.37 * * \\
(0.148)\end{array}$ & $\begin{array}{c}0.60^{* * * *} \\
(0.096)\end{array}$ & $\begin{array}{c}0.19 * * * \\
(0.059)\end{array}$ \\
\hline Observations & 16,371 & 16,366 & 16,371 & 16,366 & 10,073 & 10,073 & 13,930 & 13,930 & $\begin{array}{c}8.070) \\
8,729\end{array}$ & 8,729 \\
\hline \multirow[t]{2}{*}{$\begin{array}{l}\text { Panel B } \\
\end{array}$} & II & II & III & IV & VV & VI & VII & VIII & IX & $\overline{\mathrm{X}}$ \\
\hline & \multicolumn{10}{|c|}{ Dependent Variable: Capital-Labor Ratio (K/L) } \\
\hline \multirow[t]{2}{*}{ Sample } & \multicolumn{4}{|c|}{ Full Sample } & \multicolumn{2}{|c|}{ w/o South } & \multicolumn{2}{|c|}{ w/o West } & \multicolumn{2}{|c|}{ w/o North } \\
\hline & OLS & 2SLS & OLS & 2 SLS & 2 SLS & 2 SLS & 2SLS & 2 SLS & 2 SLS & 2 SLS \\
\hline Convict Labor (Continuous) & $\begin{array}{c}17.85^{*} \\
(10.611)\end{array}$ & $\begin{array}{c}67.64 * * * \\
(24.958)\end{array}$ & & & $\begin{array}{c}81.96^{* * *} \\
(29.081)\end{array}$ & & $\begin{array}{c}67.64 * * * \\
(25.668)\end{array}$ & & $\begin{array}{l}74.55^{* *} \\
(36.665)\end{array}$ & \\
\hline Convict Labor (Discrete) & & & $\begin{array}{l}14.48^{*} \\
(8.168)\end{array}$ & $\begin{array}{l}27.02 * * \\
(12.354)\end{array}$ & & $\begin{array}{l}28.85^{* *} \\
(12.529)\end{array}$ & & $\begin{array}{l}27.22 * * \\
(12.759)\end{array}$ & & $\begin{array}{l}77.16^{* *} \\
(36.687)\end{array}$ \\
\hline $\mathrm{R}$-squared & 0.615 & 0.412 & 0.616 & 0.416 & 0.479 & 0.484 & 0.415 & 0.419 & 0.307 & 0.303 \\
\hline Kleibergen-Paap F-stat & & 11.01 & & 33.92 & 7.255 & 26.38 & 10.49 & 32.24 & 4.909 & 15.63 \\
\hline Instrument's coefficient & & $\begin{array}{c}0.45^{* * *} \\
(0.105)\end{array}$ & & $\begin{array}{c}0.43^{* * *} \\
(0.133)\end{array}$ & $\begin{array}{c}0.41 * * * \\
(0.111)\end{array}$ & $\begin{array}{c}0.47^{* * *} \\
(0.161)\end{array}$ & $\begin{array}{c}0.45^{* * *} \\
(0.108)\end{array}$ & $\begin{array}{c}0.43^{* * *} \\
(0.137)\end{array}$ & $\begin{array}{c}0.59 * * * \\
(0.086)\end{array}$ & $\begin{array}{c}0.17 * * * \\
(0.026)\end{array}$ \\
\hline Observations & 7,859 & 7,722 & 7,859 & 7,722 & 4,243 & 4,243 & 6,974 & 6,974 & 4,227 & 4,227 \\
\hline
\end{tabular}

Note: Both values of exposure to convict labor are normalized. All columns contain constant, county, and decade fixed effects. The following variables are used as controls: ln of total population, urban share, share of Black population, share of women, share of foreign-born population, ln of manufacturing output, employment share in manufacturing, employment share in agriculture, ln of value of farm products, number of dwellings, number of slaves (for 1850 and 1860), and county-specific linear trends. Columns with second-stage results include first-stage coefficient of the instrument on the explanatory variable. Robust, clustered-by-state standard errors are in parentheses. ${ }^{* * *} \mathrm{p}<0.01,{ }^{* *} \mathrm{p}<0.05,{ }^{*} \mathrm{p}<0.1$

In Panel B, I test whether convict labor affected industry composition, the capital-labor ratio in particular. Both the OLS and IV coefficients are positive and significant. Column II shows that one standard deviation in exposure to convict labor increases the capital-labor ratio by $7 \%$ of its standard deviation. Evaluated using the Column II estimate, a county at the 75 th percentile experienced a 3.4 percent larger increase in mean capital-labor ratio than a county at the 25th percentile. Similarly, Columns III and IV show results for the sharp measure of convict labor. 
Table F2 - Convict labor and Patenting: Placebo

\begin{tabular}{|c|c|c|c|c|c|c|c|c|c|c|}
\hline \multirow{4}{*}{ Sample } & I & II & III & IV & 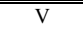 & VII & VII & VIII & IX & $\overline{\mathrm{X}}$ \\
\hline & \multicolumn{10}{|c|}{ Dependent Variable: Number of Patents in Noncompeting Industries per 10,000 people } \\
\hline & \multicolumn{4}{|c|}{ Full Sample } & \multicolumn{2}{|c|}{ w/o South } & \multicolumn{2}{|c|}{ w/o West } & \multicolumn{2}{|c|}{ w/o North } \\
\hline & OLS & 2 SLS & OLS & 2 SLS & 2SLS & 2SLS & 2 SLS & 2 SLS & 2 SLS & 2SLS \\
\hline Convict Labor (Continuous) & $\begin{array}{c}0.166 \\
(0.133)\end{array}$ & $\begin{array}{c}0.132 \\
(0.109)\end{array}$ & & & $\begin{array}{c}0.149 \\
(0.092)\end{array}$ & & $\begin{array}{c}0.116 \\
(0.074)\end{array}$ & & $\begin{array}{c}0.004 \\
(0.005)\end{array}$ & \\
\hline Convict Labor (Discrete) & & & $\begin{array}{c}0.004 \\
(0.012)\end{array}$ & $\begin{array}{c}0.184 \\
(0.118)\end{array}$ & & $\begin{array}{c}0.182 \\
(0.132)\end{array}$ & & $\begin{array}{c}0.158 \\
(0.115)\end{array}$ & & $\begin{array}{c}0.012 \\
(0.015)\end{array}$ \\
\hline R-squared & 0.984 & 0.945 & 0.983 & 0.874 & 0.955 & 0.893 & 0.947 & 0.880 & 0.972 & 0.972 \\
\hline Kleibergen-Paap F-stat & & 16.52 & & 6.753 & 13.91 & 5.759 & 15.53 & 6.598 & 40.11 & 14.71 \\
\hline Instrument's coefficient & & $\begin{array}{c}0.46^{* * * *} \\
(0.114)\end{array}$ & & $\begin{array}{l}0.36^{* *} \\
(0.144)\end{array}$ & $\begin{array}{c}0.43^{* * *} \\
(0.121)\end{array}$ & $\begin{array}{l}0.39 * * \\
(0.167)\end{array}$ & $\begin{array}{c}0.45 * * * \\
(0.117)\end{array}$ & $\begin{array}{l}0.37 * * \\
(0.148)\end{array}$ & $\begin{array}{c}0.60 * * * \\
(0.096)\end{array}$ & $\begin{array}{c}0.19 * * * \\
(0.059)\end{array}$ \\
\hline Observations & 16,371 & 16,366 & 16,371 & 16,366 & 10,073 & 10,073 & 13,930 & 13,930 & 8,729 & 8,729 \\
\hline
\end{tabular}

Note: Both values of exposure to convict labor are normalized. All columns contain constant, county, and decade fixed effects. The following variables are used as controls: ln of total population, urban share, share of Black population, share of women, share of foreign-born population, ln of manufacturing output, employment share in manufacturing, employment share in agriculture, ln of value of farm products, number of dwellings, number of slaves, and county-specific linear trends. Columns with second-stage results include first-stage coefficient of the instrument on the explanatory variable. Robust, clusteredby-state standard errors are in parentheses. ${ }^{* * *} \mathrm{p}<0.01,{ }^{* *} \mathrm{p}<0.05,{ }^{*} \mathrm{p}<0.1$ 


\section{Additional Figures and Tables}

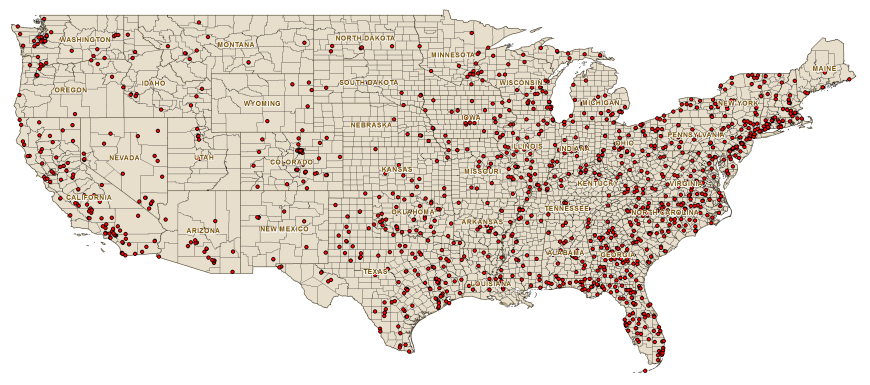

Figure G1. Prisons in 2005

Note: Red dots represent locations of state prisons that were employ prisoners in 2005. Source: Addresses of state correctional facilities are from the Census of State and Federal Adult Correctional Facilities (ICPSR 24642), and coordinates are found using R.

Table G1-Evolution of COnvict labor: Shares for values of Prison-made goods

\begin{tabular}{cccccccc}
\hline System & 1886 & 1895 & 1905 & 1914 & 1923 & 1932 & 1940 \\
\hline \hline Convict leasing & 15 & 11.4 & 9 & 1.8 & 0 & 0 & 0 \\
Contract & 70.4 & 43 & 48.6 & 26.2 & 24 & 8 & 0 \\
Piece-price & 6.1 & 19.9 & 9.4 & 6.5 & 16.2 & 14 & 0.5 \\
State-account & & & 13.9 & 36.9 & 21.6 & 16.4 & 15.6 \\
State-use & 8.5 & 25.7 & 10.7 & 22.2 & 18.1 & 28.2 & 60.2 \\
Public works and ways & & & 8.4 & 6.4 & 20.1 & 33.4 & 23.7 \\
\hline \hline & 100 & 100 & 100 & 100 & 100 & 100 & 100
\end{tabular}

Note: State-account, state-use, and public works and ways systems were reported together as a publicaccount system before 1905. Source: Computed using data from the U.S. Department of Labor. 